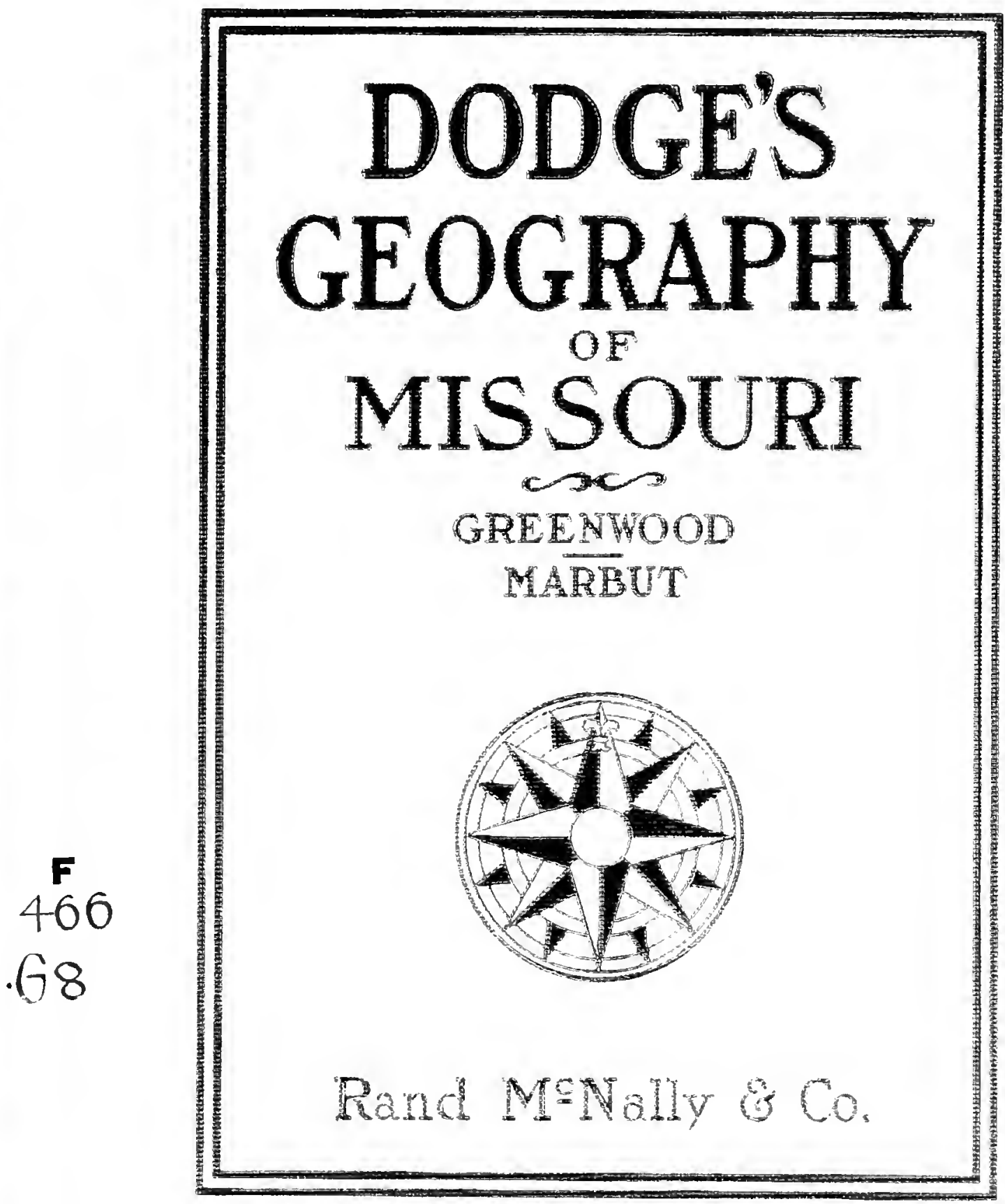




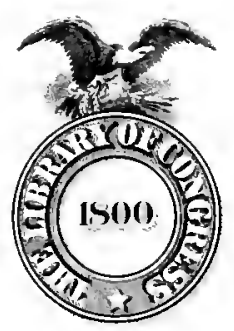

Iliss

biok

I mmtigll I"

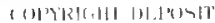

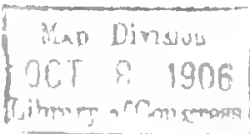




\section{. .}





\section{DODGES}

\section{GEOGRAPHY OF MISSOURI}

lis

J.M. (IREENWOUH)

Superintendent of Silhols, Kansos city. Hissour

and

$$
\text { C. F. MARBLT }
$$

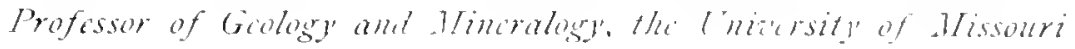

$$
\text { PAKTI }
$$

MISSOURI AS A WIIOLE

PARTH

THE GROWTH AND DEVELOPMENT OF CITIES

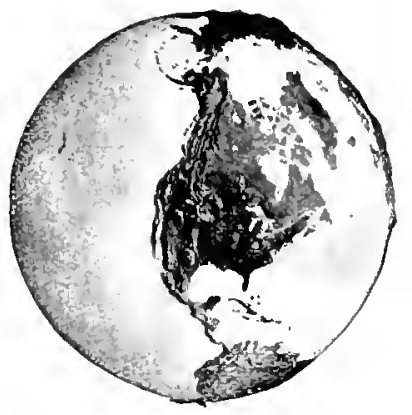

CHICAGU NEW YORK IONIUN 


\section{Doogr's Grographical Srrirs}

ظy RICHAkL ELWML DOHGE

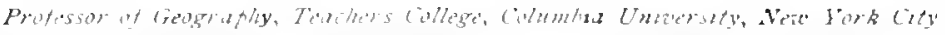

Dodge's Two-Book Series of Geography DODGE'S ELEMENTARY GEOGRAPHY . \$.65

Speckal Method Cannal Relatums tratenl by induction. Reasioning Irom consestlences to catthes

\section{I'.IRT I-HUAE GEOBRAPIY}

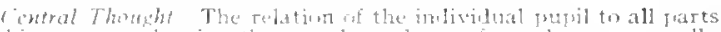

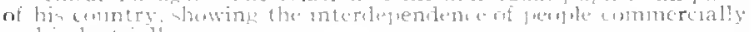
anel industridily

\section{P.IRT II-WORLD RELATIONS AND THE CUNTINENTS}

Contral Though The relation of the imlivilual pught to the

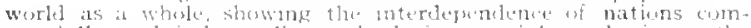

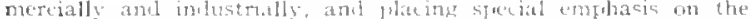
liwes and acelujations of the frealle.

\section{DODGE'S ADVANCED GEOGRAPHY}

$\$ 1.20$

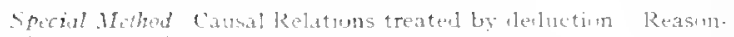
ing trom callses to contiofuences.

\section{I'HRT $l$-TFIE I'RINCIPLES OF GEOGRAPHY}

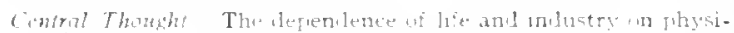
cal enviruntent

P.LTT $1 I-$ COMPARATIVE GEOGRAPHY OF TIE CONTINENTS

Contral Though Comneree and industry as well as fwiticit

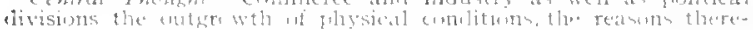

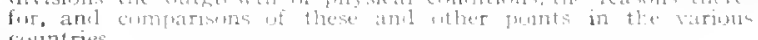
chuntries
Dodge's Geography by Grades

Book One. HOME GEOGRAPHY AND WORLD RELATIONS . . . . \$.35 IART I-HUME GEOCRAPHY

Cinlral Though The relatum ai the induvilual furpit to all

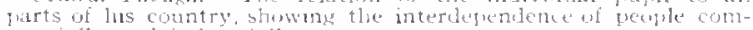
mercially ind industrially"

\section{I'ART II-WURLD RELATIONS}

Central Though Tle relatum of the induvilual futeil to the

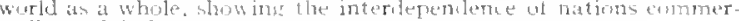
cully and industrkally

Book Two. ELEMENTS OF CONTINENTAI GEOGRAPHY

$\$ \cdot 50$

SPecial emphasis on the lives and oceupatums of freorle.

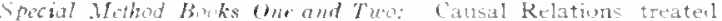
by indmetion Roastning from consequentes to catuses.

Book Three, PRINCIPLES OF GEOGRAPHY AND NORTH AMERICA

$\$ \cdot 75$

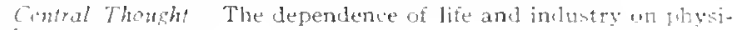
cal envirutiment.

Book Four. COMPARATIVE GEOGRAPHY OF THE CONTINENTS.

$\$ .70$

Central Thouthe Commeree and in lustry as woll as inlitical

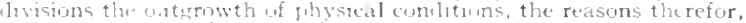

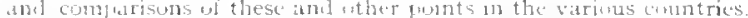

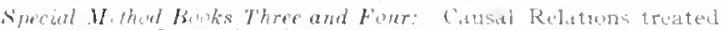

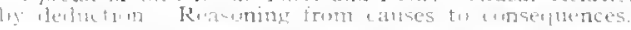

\section{GENERAI, CRITICS FOR BOTH SERIES}

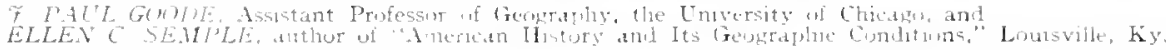

SPECIAL CRITICS FOR THE ELEMENTARY GEOGRAPHY AND BOOKS I. AND II. BY GRADES

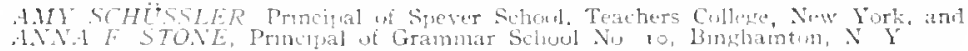

SPECIAL CRITICS FOR THE ADVANCED GEOGRAPHY AND BOOKS III. AND IV. BY GRADES

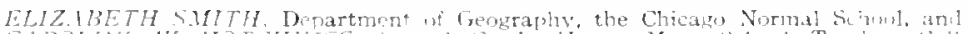

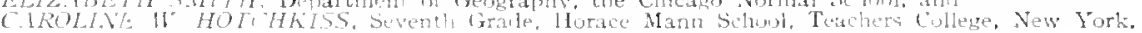

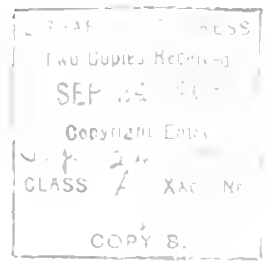

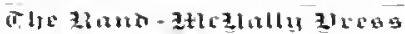




\section{TIIE INTROIOUCTON}

$\mathrm{H}^{\prime}$ ME Geography is ustally the first work to he taken up in any study of geography hecause leginning stulents need to know first the geography of the locality in which they live, in which they are most interested, and with which they are most familiar from personal experience. The results gained from a stuly of the region they can see gives them the ability to understand remote regions that can only le pictures or deseriled to them Because nur own home locality is of most interest th us is also a reason why we need to know it letter than we need to kmow any other region of the world. Hence at some time during the school course it is most vialualle to male a careful stucly of the state or grouj of states in which we live that we may have a better understanding of the geography about us than we can get from the necessarily lorief accounts given in a text-hook of geogriluly.

In a text-look of geograplly we stucly the relation of one state or group of states to the whole country of which our home region is a part, and our commercial relations to the world as a whole. It follows that in such a treatment the characteristies that distinguish our own home regions must largely be lost to sight in the consideration of the great features that divinguish the country as a whole.

In a special text-look levoted to one state or group of states we can learn more about our orrn region, its important surface features, its climate, the occupations of its people, its products, its local commerce, its history, its hief cities, anl many other features of great interest to us. Hence we need to make a special study of nur home lociality after we have studied the larger region of which it is an important part. A local gergraphy is not only valualie for sturly in school that we may know well the region alout us, lut it is valuable also as a reference volume to which we can refer for facts alout our own state in our homes whenever in our realing or conversation some question arises concerning our own state which needs to $1 x$ answered at once.

In this text-look the surface features, the climate, the soil and other natural resources which betermine the occupations of the prople are studicil first because they are the large features which determine the listrilution and success of industries. One of the great lessons the student learns in gengraphy is Man's absolute dependence upon Niture for lis existence. In Missouri, as in other regions, topouraply ancl clinate frointed out the jath of levelopment that communities must follow in urker to make sure their existence within its horders. In the gages that follow, the sturint finds traces the fundamental conditions that have moulderl Missmri life. Ifter these cone the histurical erents that are limblmarks in the growth of the state, and then the stuly of the industrial and commereial features is taken 11 . To these, which explain the reasons for the development and growth of the larger cities, and which show us why our own region is important to the country as a whole, careful attention has been given.

Certain facts like the distrilution and claracter of educational institutions, the distribution of congressional districts, and the form of government in the region are included, hecause our linowlerge of our own locality woulil lx incomplete without them. These fittingly illustrate the golitical unity that hincls together the interests of all the indiviluals who form the boulypolitic which we call the stilte.

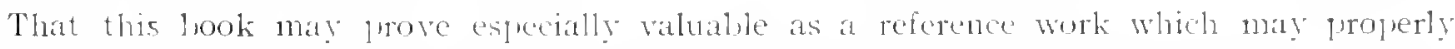

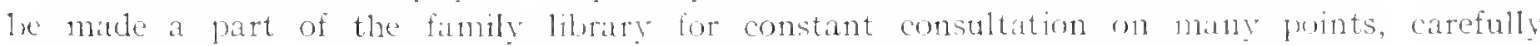

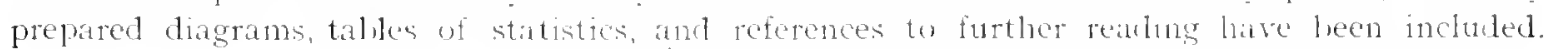




\section{THE TABLE OF CONTENTS}

The Inthduthn . . . . . . . . . . . . . . . . . II

PART I. MISOTRI.W.1 HHOLE . . . . . . . . . . . . . . . . . . I

PART II. THE GROHTH AND LEVELOPMENT OF CITIES. . . . . . . . . . . 25

Alds for Tild hets

Suggestions for Collateral Rethings

Reference Tables and Dingrams

lndix

\section{A LIST OF THE IALS ANI DIAGRAMS}

A Relief Map ot Mnsour

A Political Map of Missonti

A Plyyical Map of Missonra

The Distrubution of Mantle Rocks in Missma

The Distribution of Bed Rocks in Missonti

The Annual Rainfall it springtictl, Mo, from

I8S8 to 1004

The Ammual Ramfall at kenkuk, la., from ssis to s 004 .

The Wean Innual Rainfall amel Tumprature of Missouri

The Earliest Explomatums and Suttements on Missouri

The Productom of cirn fue Sefuite Mrle

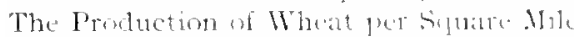

The Productum of Ilaty and fortage per suluare Mile.

The Protuctuon of Onts per Sipuare Mile

The Value of Frunt per sifuare Mile

The Value of firm l'mulucts per hipare Mile

The Distribution of Hugs pers suare Nike

The Distribution of 11usts, Mules, ant Asses per Sifuite Iile

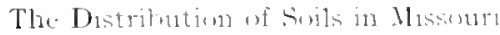

PAIE

1

$2-3$

$+$

()

6

$S$

$\dot{x}$

$i$

1)

1)

11

12

12

13

14

$1+$

15

12

(1)

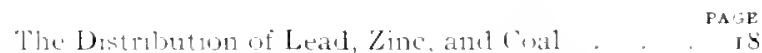
Cinctio of Vandaturing Industries in Missouri, Slonwn ly Value of Proulucts, in Mrllions af

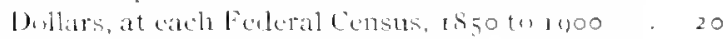
Voluc of Manufacturen Pronlucts, in Millinms of Dullars, ("insus of rooo

Vilue of Sifueial Manufactured Profucts, m Millums of Dollars, in Missouri, in ruo . . . . 20

The Cimpressional Districts of flissour, Inot , . 22

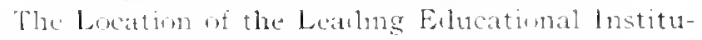

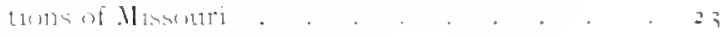

The Density of Population per Sumate Mile in Wissinri, at each Consus, ISioto luoo. .

The butrutution of Lrtan Population in Miscouri. renciun of 1 1100

Irap) of the rity if St. Louis and Vicinity. . . 20

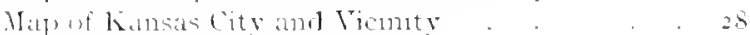

llatp of the rity of St Joseph . . . . 20

Value of Agricultural Pruducts in Millions of D) Hliss, Cousus of 1000

Inopmetion af Persons Engaged in Euch Clitus of

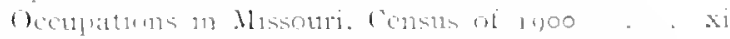

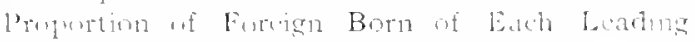
Xatirmality no Mresenti, Census ut 1000

\section{A LIST WF THE ILLESTRATIONS}

Trout Glen, Ha Ha Thy. PABE

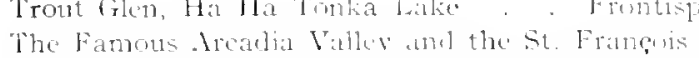
Monntaims

In a Forest if the (1/ark Reurem

Revetment Work in l'rengers an at Bund we the Missomi River.

In the Granite Areat of the O)arl Regron

A steep Bluff on the nissuri kiver Thmonas Hart Bunton o

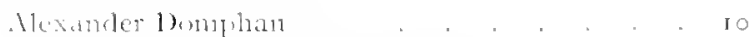

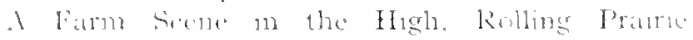

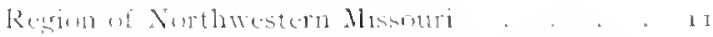

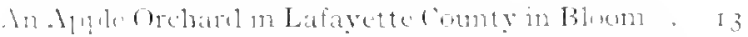
lacking beaches for Market, Krahkonong, Oregon Cistinty

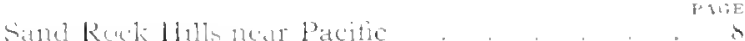




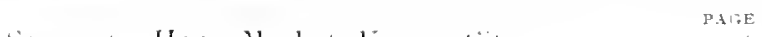

Senc at a Horse Warket, Kansas (ity. . . 10

Hogs in a Blue Grass l'asture, Marim Comnty . I . I

Seene on a Missouri Stock fiarm . . . . . I7

1 Poultry Farm in Southwestern Missouri. . I

A Group of Prize Angora Goats . I7

Mining Seene at Aurora . . . . . . . Is

A Nine in the Southwestern Learl and Zinc

District. . . . . . . . . . Is

Lime Works in Marion County . . . . . 10

Loarling Railroar Ties for Shipment . . . I

1 Sand Dredge at Work. . . . . . . 10

A General View of the Stock Yarels at St. Jose th . 20, 2 I

A Clay-working Plant, Deepwater, Henrycinty . 2 I

I Steambat on the Mississipni River . . . . 2 I

The School of Hines at Rolla . . . . . . 22

A Creneral View of the State University at Columbia . . . . . . . . . 22

The Second District Normal School of Missouri, at

Warrensburg . . . . . . . . . 24

The First District Normal School of Missouri, at

hirkstille . . . . . . . . . 24
The Third Distriet Normal Sichorel of Nlssouri, at Cape Girardeats . . . . . . . . 21

The Water Front, St. Louis, ass seen from the Shorc at East St lants. . . . . . . . 27

biew in the Mnsoneri Butanical Garden-Shaw's Giarden . . . . . . . . . 27

Looking bown Into the Heart of the Business Dostrict of Sit. Londis from the Court House . . 27

Elerenth Street East from Main Street, Kansas city. . . . . . . . 25

The Pergola un the Pasen, Kansas City . . . 28

The State Capitul at Jefierson City . . . . 20

A View of the City of Hannilial . . . . . 30

Samud L. Clemens (Mark Twain) in the Doorway of his old Home at llimnibal . . . . . . 30

The Home of Huckleberry Finn, Hamnibal . . 30

Acadmic Hall Main Builling of the University of Nlissouri at Cuhmlia . . . . . . . $3^{I}$ The City of Lousiana . . . . . . . . 3 I A Scene on the Neramec River Franklin County. $3^{2}$

A Peach Vursery near Louisiana . . . . . 32 


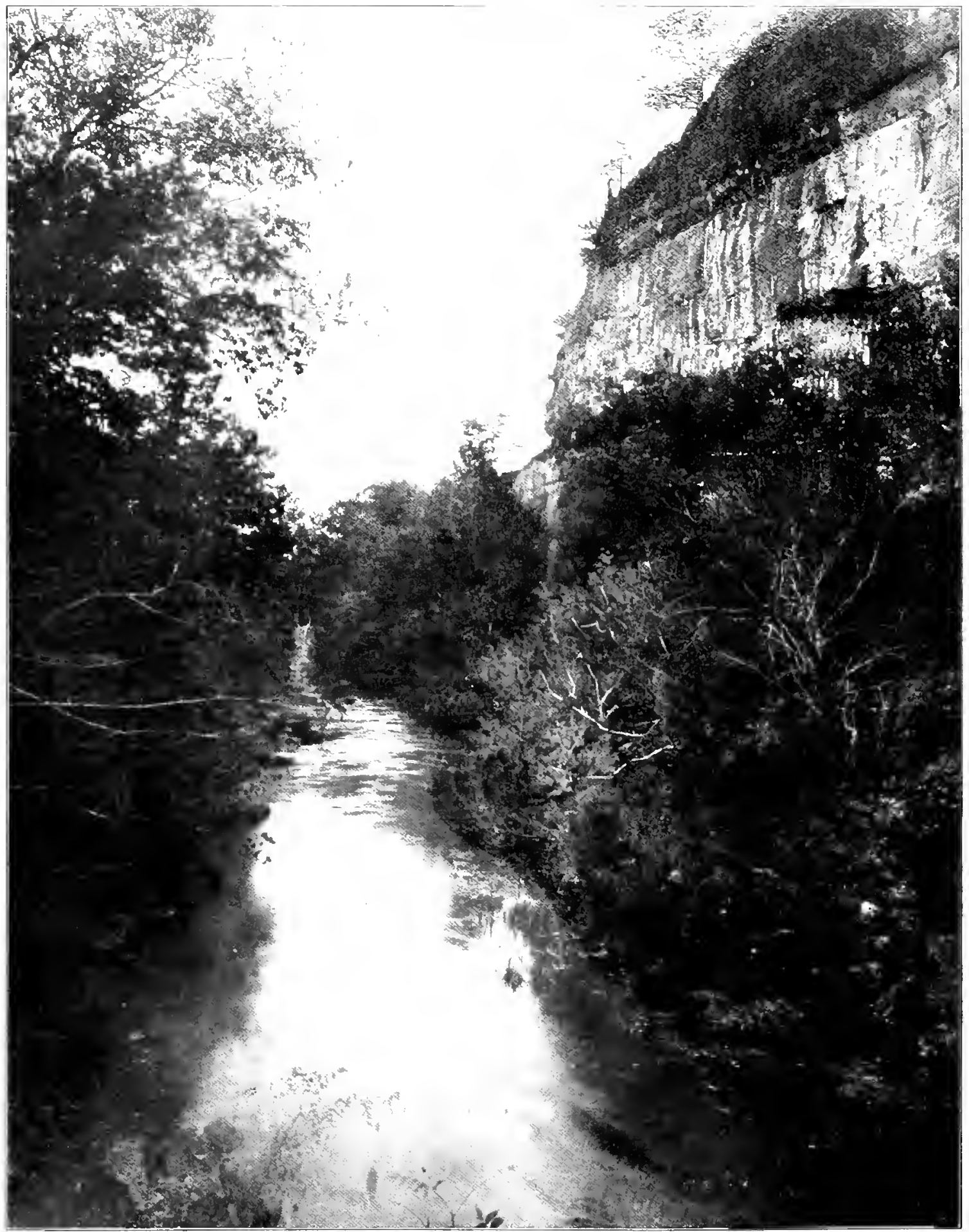

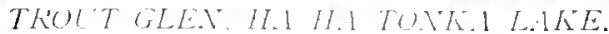




\section{THE GEOGRAPIIY OF MISSOURI}

By J. M. Greenwood, Superintendent of Sehools of Kinsas City, Mo, and C. F. MARBut, Professor of Geology and Mancralugy, the Lneversity of Missour.

\section{MISSOURI AS A IVHOLE}

Location. Missouri, one of the elief states of the Nississippi Basin groul, owes its alvancement largely to its position noar the geographical center of the Uniteristates amklof the Mississipyi Basin.

(1) $1 \mathrm{r}$. Geos. Fis. 192.) Along the easternborderflows the largest riverof the United States, while the seeond river in size flows directly across the state. These rivers, with their tributary streams, make up great stretches of natural highways that early attracted the

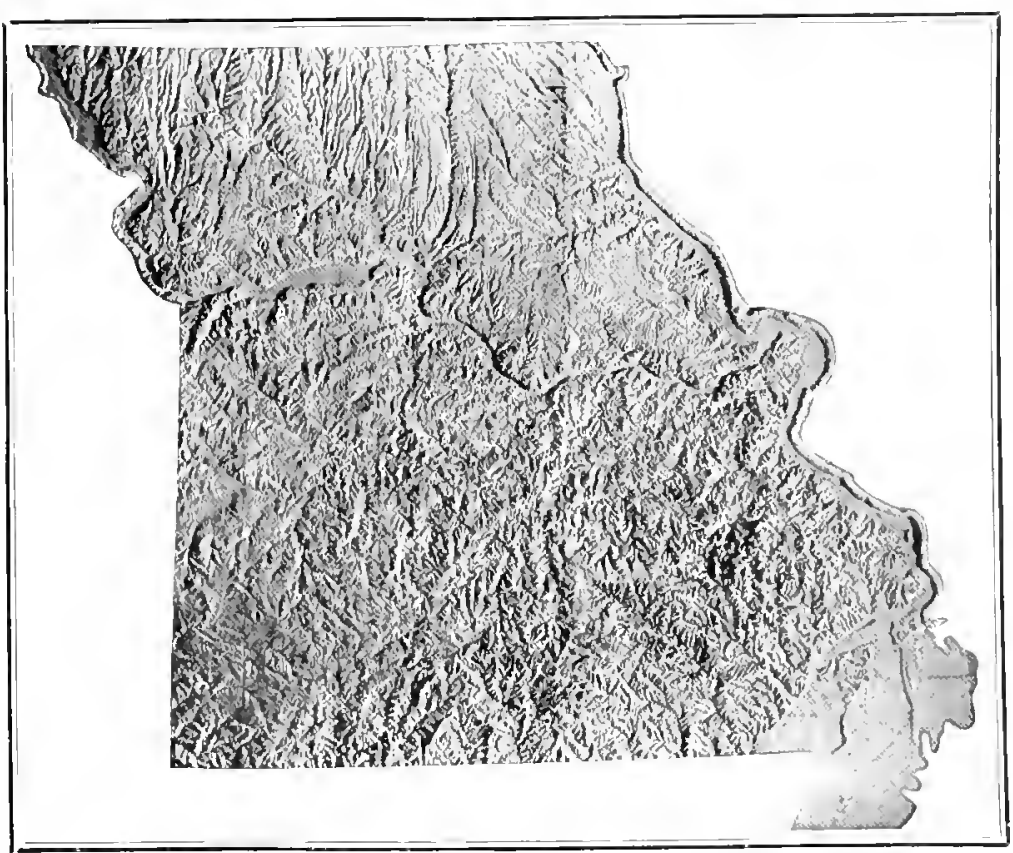

Fig. I A relex map of Missour.

great tracts of wordland, and within the vallevs and plitins hundreds of sruare miles of fertile faming lands afforded boundless inclustrial opportunities for the people.

Size. Missnuri has an extreme length from nortl to south of 328 miles, and a lrearth varying from 305 miles to 208 miles. This gives the state a total area of $60,+15$ square miles, of which $650 \mathrm{squar} e$ miles are water surface. The stit te boun]ary, as a whole. is throut $r,+\infty$ milus in length. Of this milenge the laniboundaric's make up allout 665 miles and the brumelaries in rivers traffic out of which grew naturally the settlement and development of the region. Beneath the soil of Missouri vast stores of mineral wealth, upon the hills and lowlands the remainder, or about 770 miles. (Fig. 3.)

Surface, The surface of Missouri presents great variety. The state lies in the center of the Mississippi Basin, one of the largest

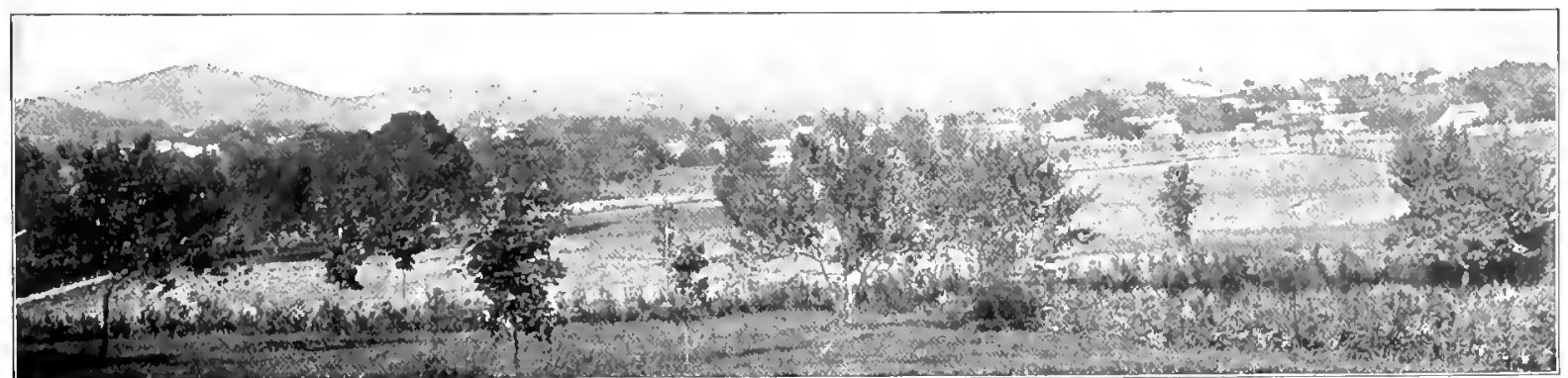

FIG 2. The famous Arcadia Valley and the St. Francois Mountains

A characteristic vicu in the Osark region 


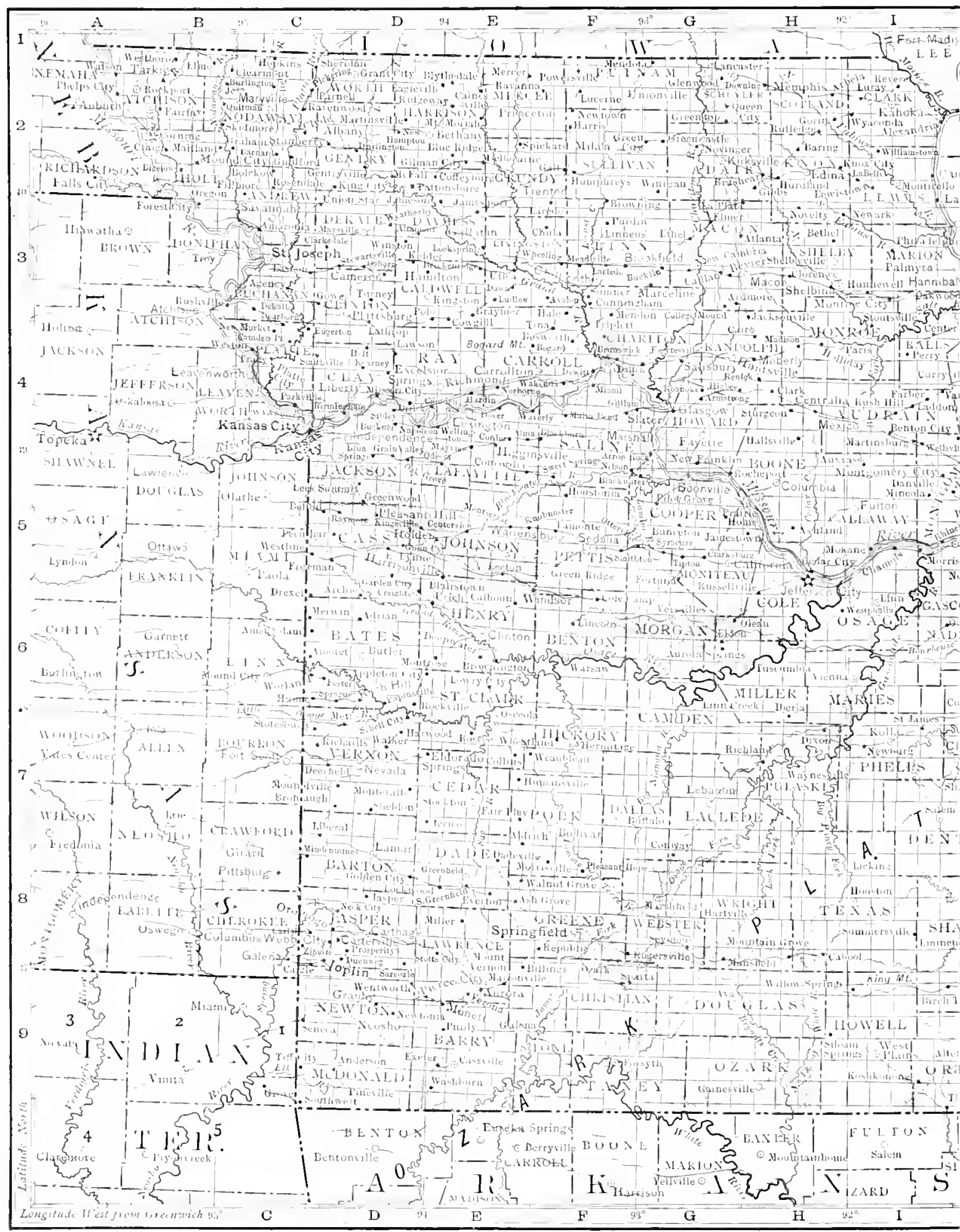

Fig. 3. A politzcal map of Missourz. 
(1) I,600 feet above sea level, hat variations in level dis not take pluce ripilly.

The Ozark Borler is merely the sloping helt letweet the Ozark Platean and the lower lying prairie region. Here the country is lower, the valleys wiler and more shallow than in the Platean region. (Fig. 4.)

The St. François Itountains, the highest elevations in 7 issunt, consist of a grea many rather high, runilerl, or wal-shapel hills all underlaid by granite rocks. (Figs. 2 and 3.) They are not so ligh as they once were, and we call them mountains because once the r were mountains.

The pratic region in Missouri has two main subrlitisions-a low easterly are and a higher westerly one. The easterly one incluiles the larest area of smooth land in the

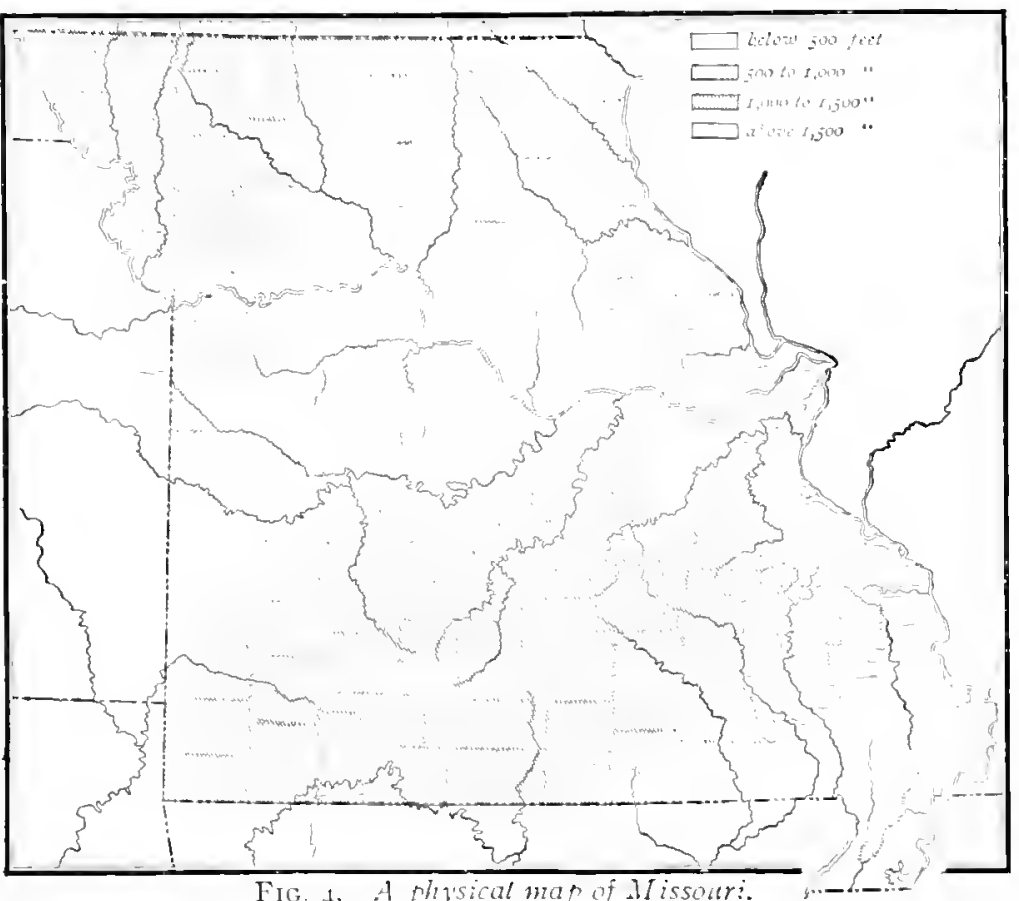
state. Its eleration varies from 550 tu 050 feet above sea lerel. Its valleys are all shallow and in many places they are very wide.

The western part of the prabie region varies in eleration from 950 to about $\mathbf{I}, \mathrm{I} 50$ feet ahove sea lerel. Its ralleys, as a whole, aro deeper and narrower than those in the eastern part. In the extrume northuesten corner of the state is a small area with wider valleys but with the upland of about the same height. (Figs + and io.)

The lowlinds ocenpying the southeastern corner of the state consist mostly of low river-tonttom land. Rumning down the midWle of this lowland is a long, rather narrow ridge which lies about 500 feet above the sea level, while the lottom lanils are usually less than 300 feet alwre sea level. (ligs. I anrl t.)

Drainage. The entire eastern boundary of Missouri is washed by the waters of the Mississippi, which, lecause of its many windings, gives the state an eastern water front of 560 miles. The Missouti (Fig. 6), second only to the Mississippi in importanee, forms the boundiary along the up1) part of the western side uf the state, frotri the first print of contact to Kansas City, a distance of $2 \circ 8$ miles, where it enters Missouri. Thence it crosses the entire state, flowing southeast +30 miles to jointhe Mississippi, which it enters a few miles above St. Louis. The part of the state north of the Missouri River is drained by many rivers and their tributary streams, some of which flow into the Missouri and some into the Mississipli. The principal rivers flowing into the Missouri are the Chariton, Cimon, Platte, and the Nolaway. Those flowing into the Mississippi are the Fox, Salt, Fabius, ancl Cuive. The streams of south Missouri flow into the Missouri, the Nississippi, ant the Arkansas rivers. Those flowing into the Missouri are the La Mine Moreau, Osage, anu Cinsconade. The two 
last named streams have many large tributaries which irain a wile area of territory. The streams flowing into the Nississippi are the Aleramee and the St. Francis. Those flowing into the Arkansas River are White River, with a great many large trilutaries, and Spring River. Innumerable small streams, often haveng their urigin in the fine springs with which the country abounds, diversify the surface of the whole state. Six hundred and sixty miles of the rivers bordering Wissouri are navigable. This, arfecel to the length of the Mlissouri River witlin the state, but excluding a number of smaller streams that are navigable for short distances, gives 2 issouri more than $\mathrm{I}, 000$ miles f nurigalle waterways. (Figs. I and 3.)

The Rocks of Missouri. The surface of Missouri is made up of two kinds of material or rocks. One is composet of loose material, such as chy, sand, and gravel, and is called montle rock. (Fig. 7 .) The other kinel is haril and complact and often occurs in layers,

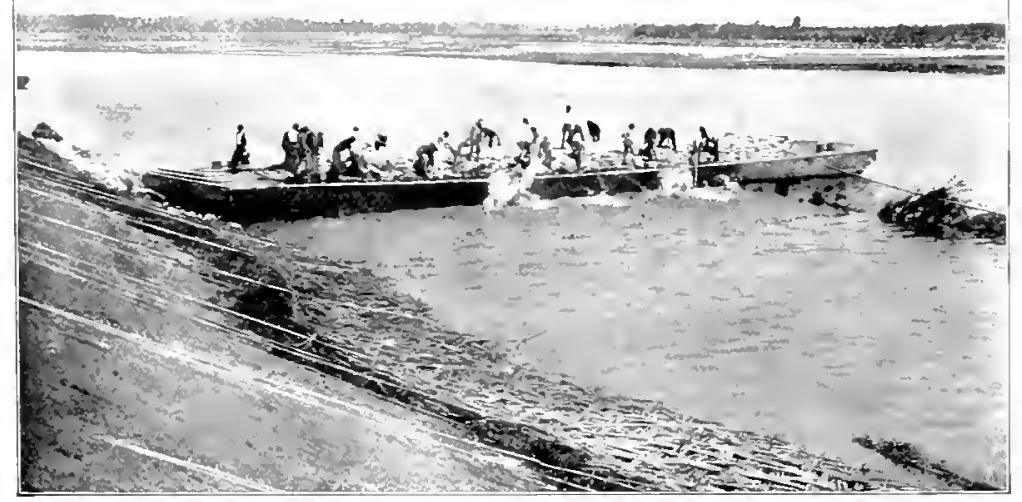

Fig. 6. Reretmont work in progress on a bend of the Misscuri Ricer. Here the action of the water is waring away and destroying the

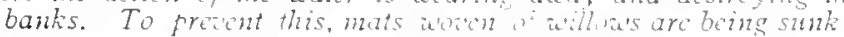
along shre on wh th reks atll be sprod, forming

such as sindstone, limestone, an 1 granite, and this we call tod rock. (Figs. 9, Io. and 11.) Everywhere the bed rock underlies the manthe rock and nearly evervwhere the mantle rock covers the bed rnck. The ber rock can be seen only on steep slopes and in a few other places where the mantle wets has been washed away. (lis.

The mantle rock in north Nissouri was brought here during the glacial period hy the great ice sheet and spreal over the top of the hed rock. (A1r. Geog. Fig. I 80 .) Lsually it is thick, especialty in the central part of this seetion, where the bed roek is rarely seen exeept in the deepest hollows. Northeist it is thinner and tho hed wok may be scen in almost any creek berl. In surth Missouri the mantle rock is thinne than in north Missouri. It was timed hure where we find it by the deciry of the exposert portion if the hed rock which may bx frund at rarying depths beneath the surface. The montle rock of north Missouri every where is a clay. Along 
the Missouri River, especially in the western part of the state, it is brumish in color and is called loess. This is one of the most fertile sections of the state.

There are a great many kinds of bed rocks in the morli, Int many of these are much alike, so we can arrange them all in a small number of sroups. While the rocks of sereral separatecromps aplear in different places in the state, those of the same sroup occur together. Diviling the whole state acenrling to the kind of unlerlying leel rock, we have font distinct regions or areas. These reurions may be caller the granite area.

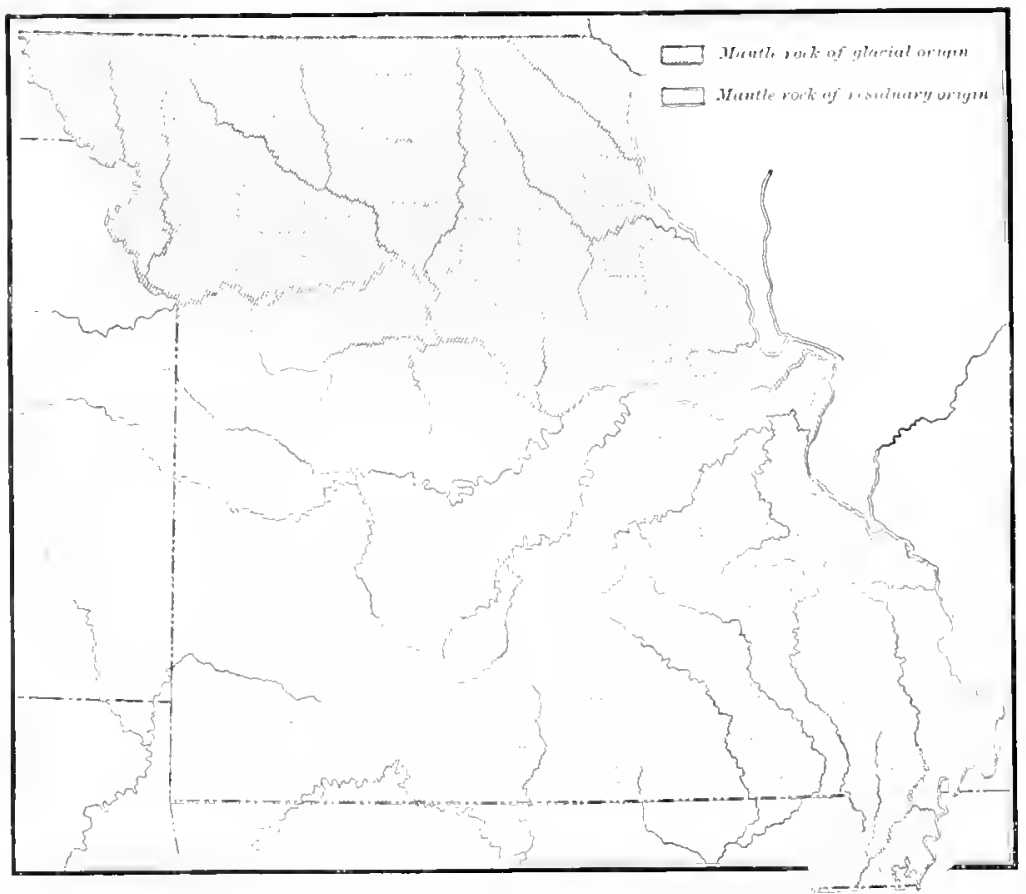

FIG. 7 The distribution of mantle rocks in Missmiri. the limestnne area, the shale area, and the tion, shape, soil, mineral deposits, healthsand-ctay area. Since the hed rock deter- fulness, and prosperity of the country, it will mines, to a considerable extent, the clevi- be wil to finow where these regions are.

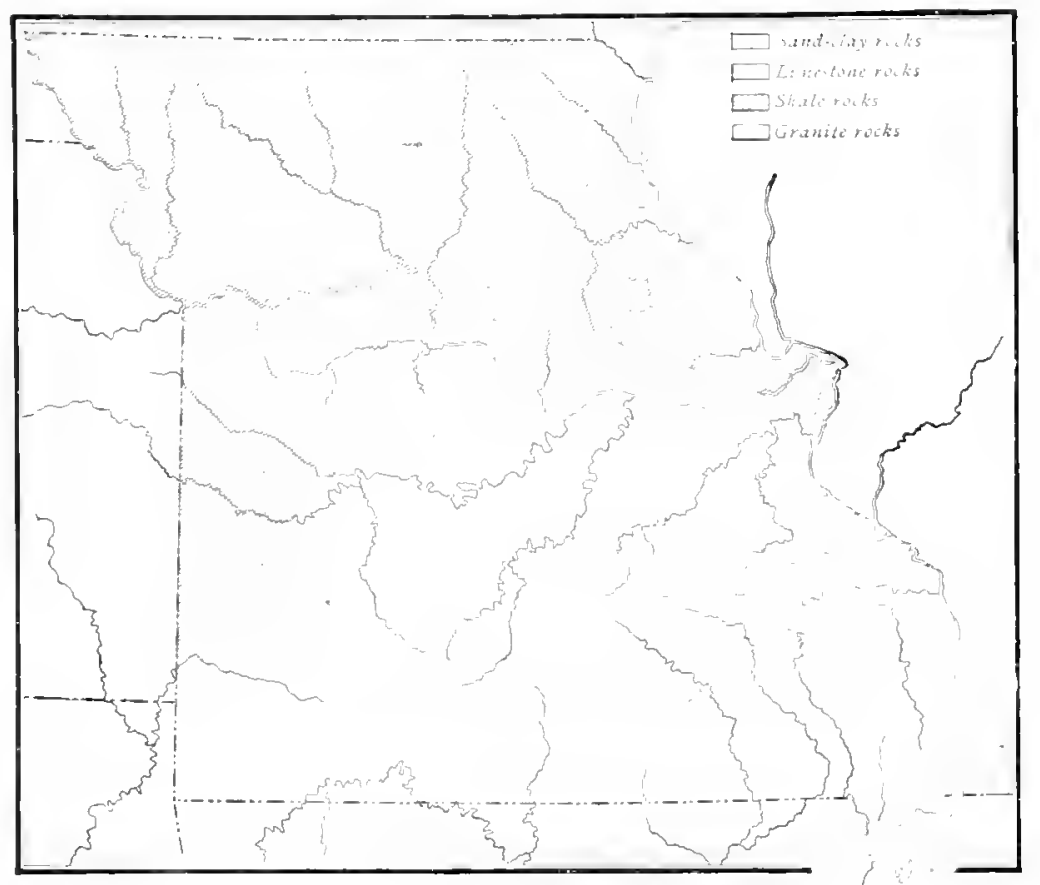

Fig. 8. The distribution of bed recks un thissouri.
The grante area lies in the sintheastern part of the state. $1 \mathrm{t}$ is not a continuous area, the rocks being foumd in patches. There are, however, a mreat many of these patches, the larrest of them necurring in St. Françis, Iron, and Madison counties. These granite rocks, all hard, crestalline, and usually somewhat pinkish in color, are the strongent as well as the oldest roclis in the state. (Figs. $S$ and o.) They are the rocks that unlerlic the hills arouni Iron Mountain, Pilot Knob, and Ironton. Many beautiful monuments are made of granite that is quarried in this region and large quantities of luilling 
stone, paring blocks, and of crushed stone are slipped from this locality to St. Louis and to other cities.

The limestone area uniterlies a large portion of the state, surroundiug completely the area underlaid by the granite group. With the latter, it

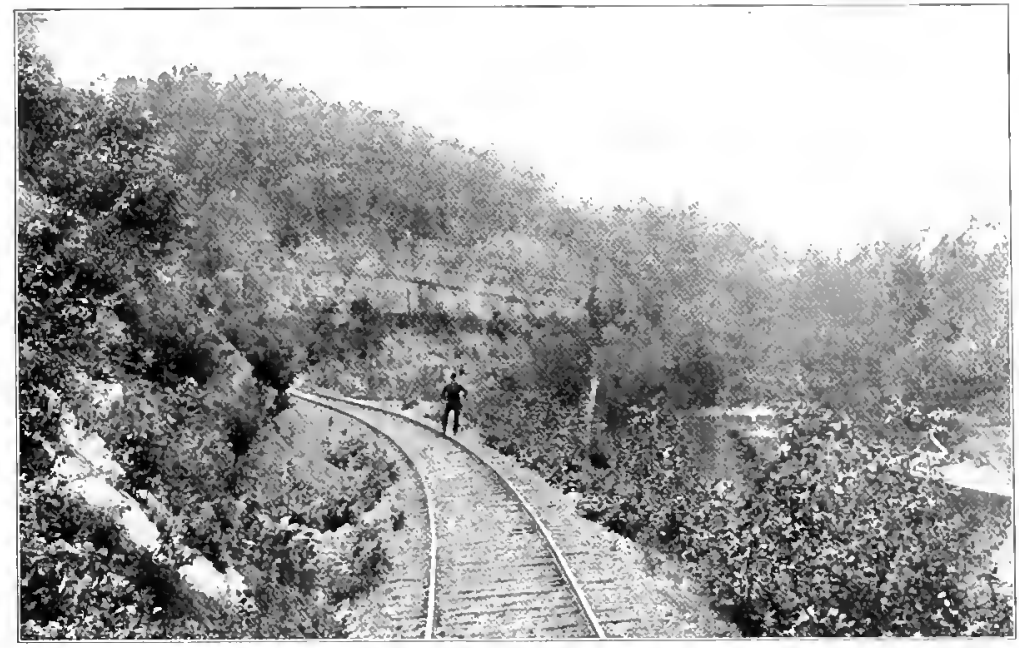

Fig. o. In the grante area of the Osark regzon The underymg lient rock of these forested hills is all granite. Across the stecply rising face of the hills, where exposure has worn away the evering of mantic ork, the granitc is platisly visible. mikte the soil rather sandy. These roeks are unimportant, however, wh en conthpared with the 1 imestones. The limestones a re not a 11 alike. Some of them are very toarse-grained and erystal. line, some are fine-grained and non-erystalline, while forms the area known as the Ozarli region. These rocks underlie a consiclerable portion of northeastern . Missouri, 1,ut they are buried so deeply beneath a thick layer of clay that others are fine-grained and erystalline. Some are in thicli, havry lerls, while others are in thin heds. In some plaees, small in area, they contain little flint, while in they can be seen only along the larger creelis and in a belt that extends northwestward and southeastward through Pike and Lincoln counties. (Figs. $S$ and 10 .)

Vithin this region, with the exception of the granite rocks, limestones predominate everywhere. They may be seen in almost every creek bluff. They contain a large amount of flint which dres not decompose readily, and hence is left as loose rochs in the soil.
In some places in this region, particularly in Dent County, there are a few thin beds of sandstone, which, in places,

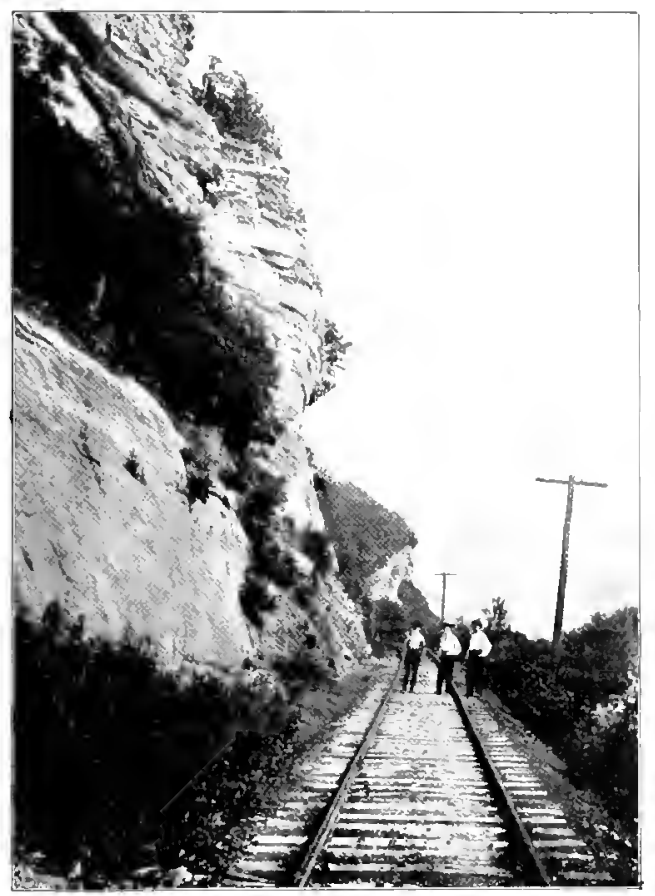

FIG Io. A stecp hluff on the Missouri River. Note how the limestone bed rot has becn bruaght inte wew by the washing awer of the loose mantle rock. others they are very flinty.

The shale area inchules most of northern Missouri and the northern part of south Nissouri. All that part of the state lying north anc1 wost of the Ozarts region is underlaid chiclly by shale, with some berls of limestone. Shale is a soft elay-like or sandy rock lying in very thin berls. Then exposed in a stecp hank it soon crumlies into elay or sandy clay It may be seen in the creek lihffs in many places. (Fis. 8.)

The eountry underlaid by these rocks is covered with a somewhat thicker layer of soil except along the creek bluffs. The 
rocks, therefore, are not seen often. If, however, nne of the larger creclis of the recrion le followed for a few miles a hank probalbly will be found where the rocks are exposed.

The sand-clay area underlies the region in the southeastern part of the state. In most of this locality no strong rock is founil until a depth of comsilerable extent is reacher, often several hundred feet (Figs. Sand 11.)

Climate. Missnuri lios near the mirlle of the north temperate belt, neither in the extrence south of the belt nor in the extrene north, and far emouh removed from the occin to have a comtinentul climate; that is, a climate suliject

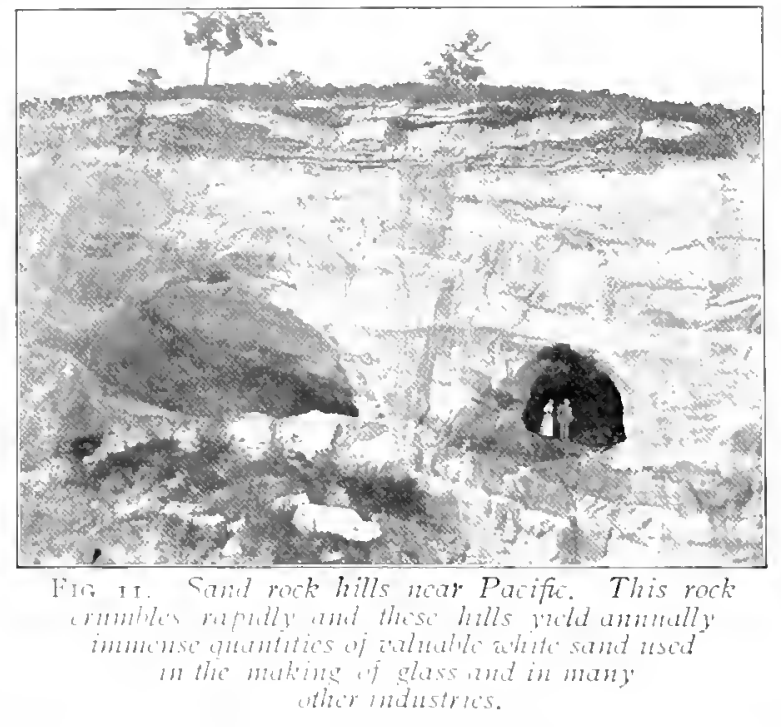

alout forty-six inches, and least in the northwestern conner where it averages less than thirty-five inches. (Figs. 12 and 13.) This rainfall is evenly distributed throughout the ycar, the greater amount oceurring in the spring and summer months. (Fig. It.)

The mean annual temperature of the state is $5+$ legrees. The average for January is 30 degrees and that for July is 77 degrees. (Fig. It and Idw. Geos. Figs. $S_{2}$ and $S_{4}$ )

Animal Life. The first settlers that came to Missouri found many will anima1s, but civilization has exterminated much of the same. In the southern part to sudden and great changes of temperature.

The prevailing winds are from the west or southwest. On acconnt of Missouri's position with respect to the Gulf of Mexico, winuls coming to the state from the south and east are warm and moist and cause either clourly weather or rain. Nesterly and northerly winds lings dy, cool, elear weather with invigorating air. (1) Geog. Firss. 90 ilnd 02.)

The annual ranfall of Missouri averages about thirty-eight inches. It is greatest in the south, where it reaches an average of

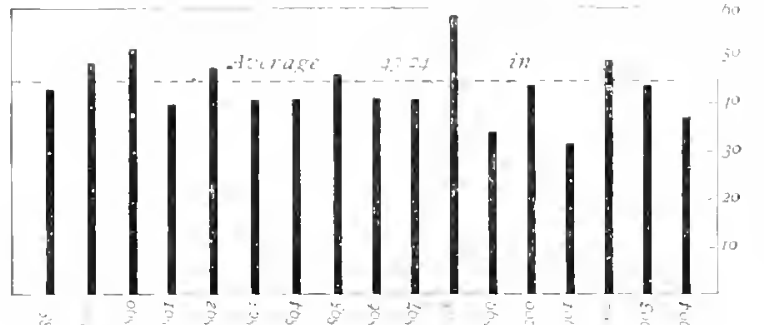

FIG 12. The anmal ramfall at Sprincfich, Mo from $1585^{\circ}$ to 1904 of the state may vet be found a few Tirginia deer and an occasional black bear or a colony of heavers. Throughout the state the wildcat and panther have disappeared, but the fox, raccoon, opossum, spuirrel, rabbit, and woodchuck are still common. N1any birds stop in their migrations, and geese and dueks are numerous in season. The wilk turkey, pheasant, and prairie chicken, formerly plentiful, are now sellom seen except in remote and thinly settled listricts. The waters of Misson1i continin many fish, anil large quantities are taken yearly The Mississippi River

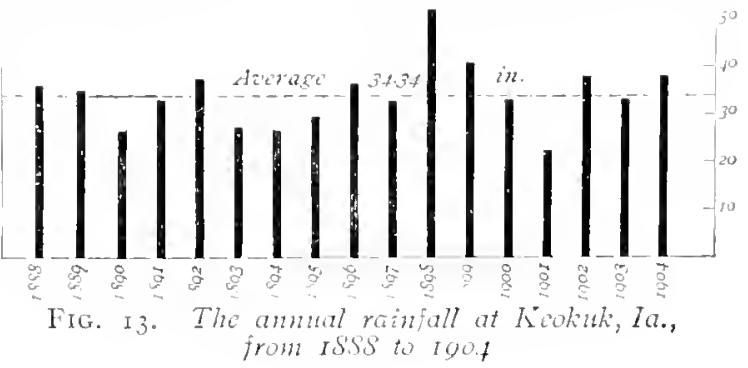




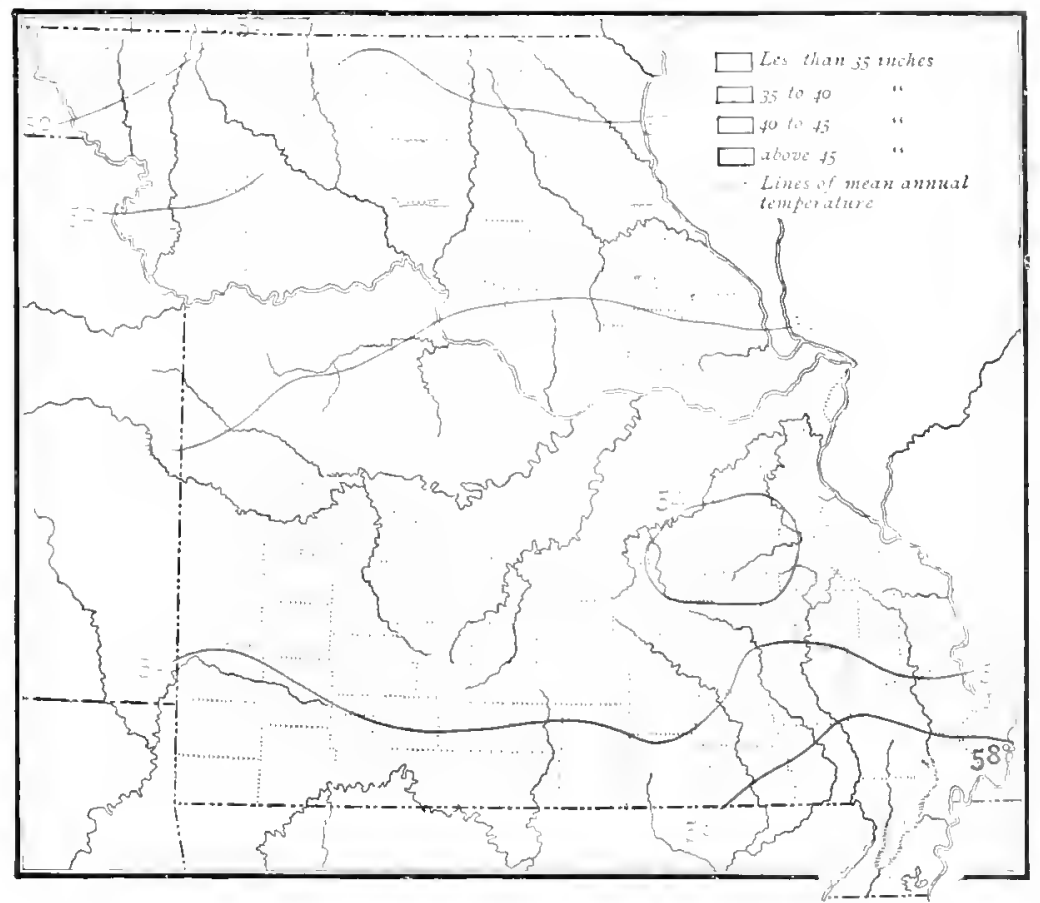

Fig it. The mean annal rainfall and temperature of hissouri.

shore in their wanderings. In 1673 Pire Mlarquette, with Louis Joliet and five men, enlarkerl at Green Bay, Wis., reacher the Missiscipri, and rescenterl to the month of the Irkansas. In 1681 la Sille passed down the Illino is into the Mississippi, which he followed to its mouth, and in the name of the French ling trak possession of the Mississigni ancl all land drainerl by that river and its tributaries.

Early in the next century the French sent out an expedition to searel for mines in the Mississippi Valley. The leard lepusits at Mine la Mnte were liscovered in 17 ig. The first suttlers were French fur is the chief fishing ground, but the Missouri and St. Francis rivers also afford good fish. ing. Under the State Fish Commission the traders who founted Ste. Gonevieve, Carmdelet, and St. Lunis. Ste. Generiere daims the distinetion of being the oldest settlement industry is extending rapidly. The mussel fisheries also are importint, about 2,000,000 pounds of shells being taken each year which are used in the making of pearl buttons.

Native Peoples. The first aceounts furnished by the fur trarlers and missionaries who risited this region tell of the Indians living in the country of the Mississippi Valley. The tribes, known chiefly as the Missouri, Kansas or Kaw, and Osage, were members of the great Sinuan family.

History. The first white men to report the Mississinpi River were the remnants of De Soto's expedition, who in $15+1$ crossed to its western

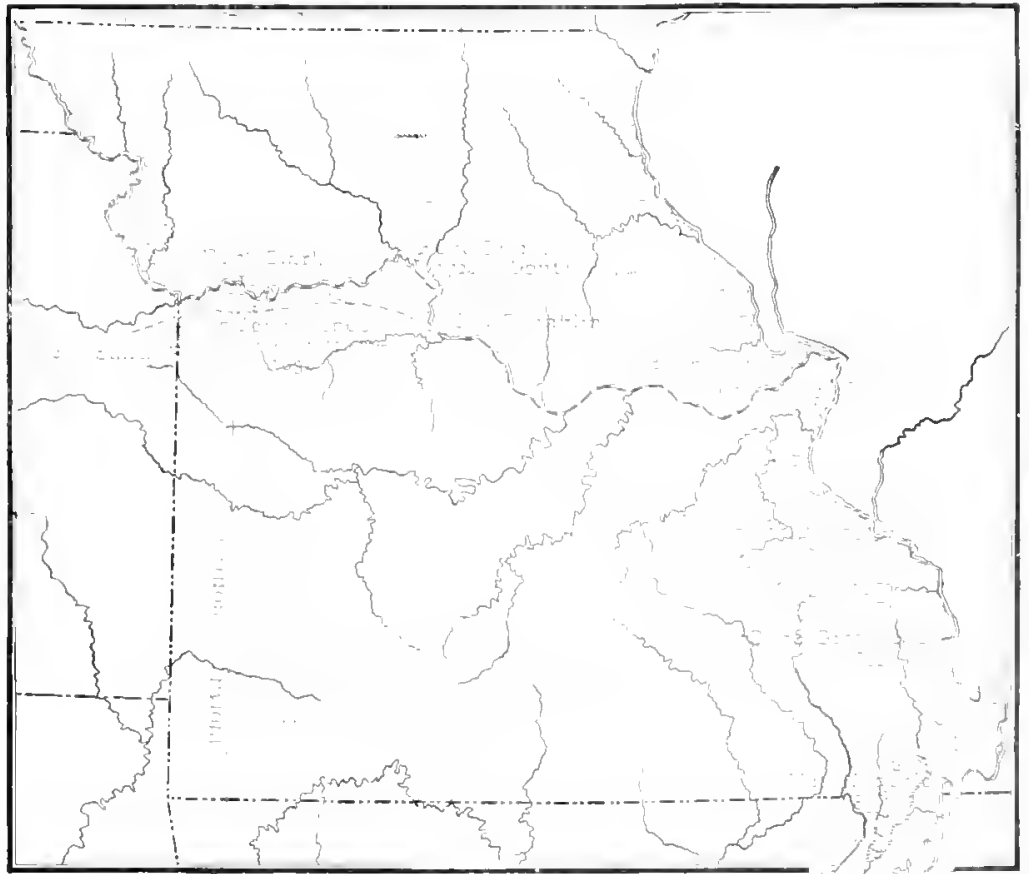

Fig. 15 The earliest explorations and settloments in Missouri 
in the state, dating its founding from 1735 . (Fig. 15.) France, having been defeated in war, celed its territory east of the Mississippi to Great Britain in 1763 , while the rast area west of the river was given to Spain. The first settlers in St. Louis were mostly French subjects, who, disliking the British, removed to that point from Illinois after the treaty of $7^{6}{ }_{3}$.

l n I 795 Daniel Boone led a band of Kentuckians across the Mississippi River and made a settlement near the Missouri in what is now St. Charles County. A stearly stream of settlers

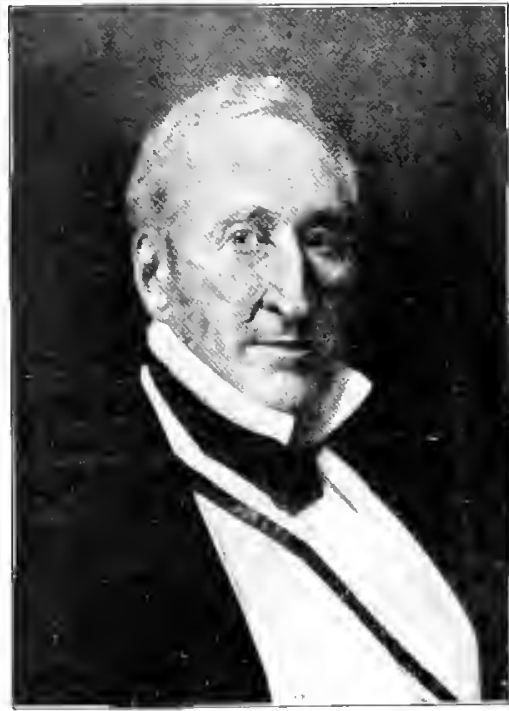

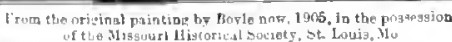
Fig I6. Thomess Hart Benton. Whe must distinguished Missourian wh the dug of Jackson. poured in from Kentucky, Tennessee, Virginia, and other southeastern states, so that when Louisiana was purchased the population consisterl largely of Americans.

Spanish rule ended in 1800 , when domination again passerl to France by the treaty of St. Illefonso, anel in April, I 803 , the United States purchased from France all the territory of Louisiana for the sum of $\$ 15,000,000$.

March 10, ISo4, the Unitel States took formal possession of the new domain, which was divided into the Territory of Orleans and the District of Louisiana. The population of the latter, which was erected into the Territory of Louisiana in I 805 , was about I 0,000 . Inmigration followed the Louisiana Purchase, settlements spreading along each side of the Missouri River and up the Missis- sippi. In 1810 the population was 20,845 . In 18 I 2 the Territury of Louisiana became the Territory of $M$ issouri. Progress was rapid and growth steady, so that in $\mathbf{1} 8: 8$ Missouri applied for admission into the Union. Then followed a struggle over slavery, and after twro years Congress passed the "Missomi Compromise" bill, by which Missouri was admitted into the Union as a slave state, lugust ro, I $82 \mathbf{r}$. The population was more than 60,000. For many years the area that remaincel after the formation of the state continued to bear the name Missouri Territury. In the meantime it was gradually reduced as new territories were formed out of it.

The first Governor of the state was Alexander McNair, and the first capital was St. Charles, which remained the seat of govern-

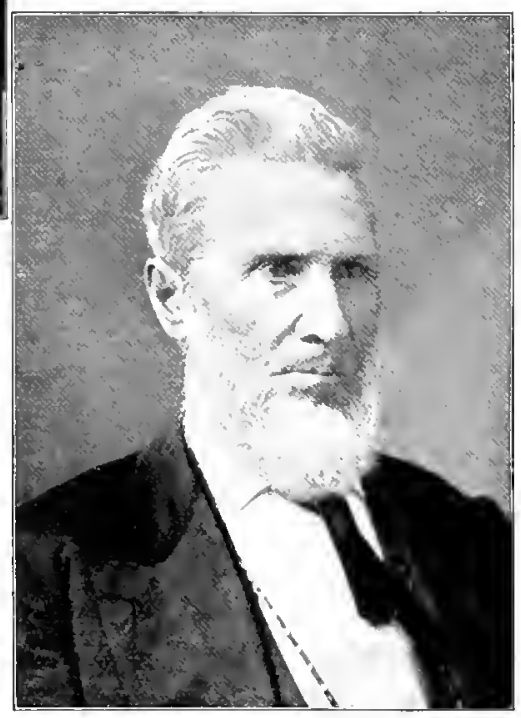

Fig 17. Alexander Doniphan, leader of the famusts briede on the march to Hexiou

the territory immediately ment until I 826 , when it was remover to Jefferson City. The stateacquirerl its present limits in 1837 by the addition of the small triangle northwest of the Missouri River, called the Platte Purchase.

Settlers continuer to conce in from Ohio and east of the Mississippi rivers. Travel was mainly along the rivers, but in I 825 commerce with Mexico was of enough importance for Congress to survey the route for the Santa Fe Trail. Senator Benton, who represented Missouri in Congress during this period of growth, was an ardent friend 


\begin{abstract}
of western interestsand one of the earliest arlvocates of at transeontinental railroad to the Pacific. (Fig. I6.)

lbout $1 S_{45}$ German immigrants legan to alpear, and within a very fewyearsoreat numbers arrived. Since I $875 \mathrm{many}$ people from New England and likerise
\end{abstract} from other of

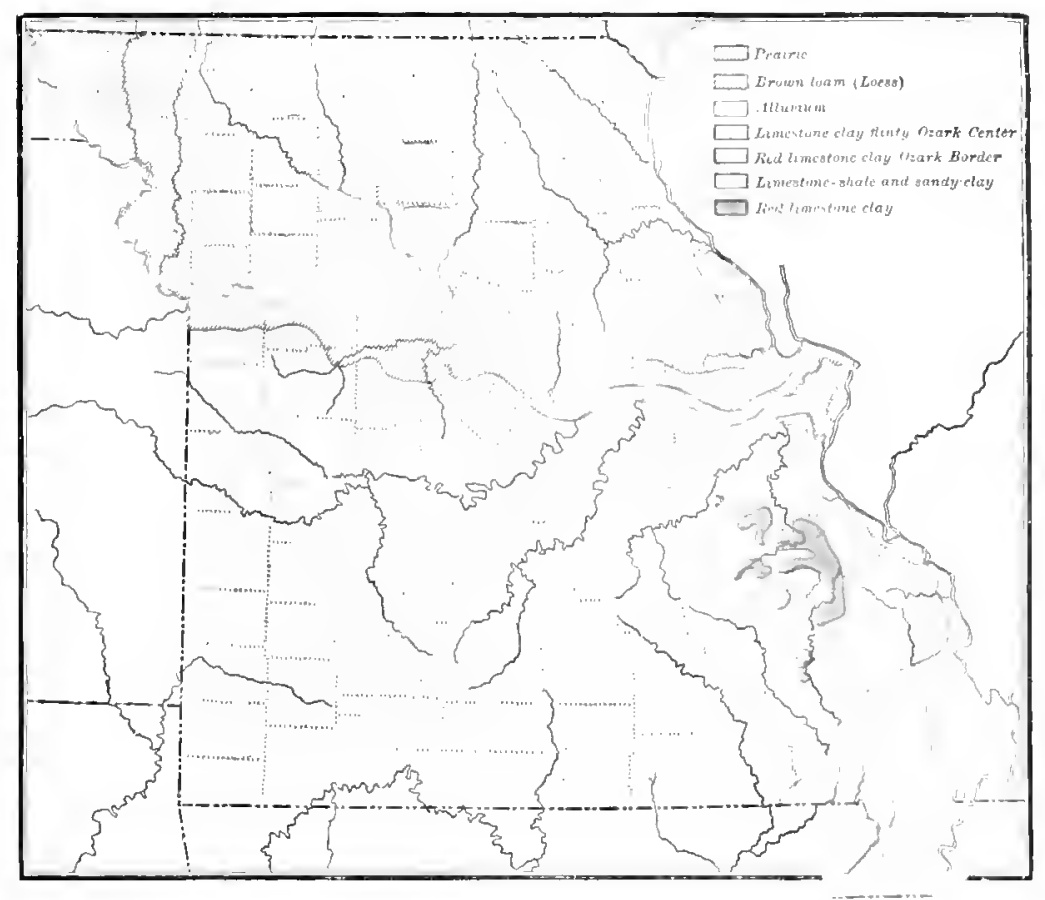

FIG. I8. The distribution of soils in Missouri. miles distant, which place he trok without sorious oploosition. The Missurrians then returnerl home, halving with a loss of less than filty men prepared the way for the acquisition of New Mexico

Agriculture. Agriculture is M issouri's leading inclustry, the stilte's greatest and most lasting the northern states have settled in Missour1

The Mexican War. Duting $\mathrm{I}_{4} 6$, in response to the call of Governor Edwards, volunteers assembled at Fort Leavenworth, and Alexander $\mathrm{TT}^{r}$. Doniphan was elected colonel. (Fig. 17.) They were joined by regular troops, and, all under the command of General Kearney, also a Missouri man, they marched in June for Santa Fe, a distance of 900 miles, which they reachel in fifty days and captured without firing a gun. Hithert, this place had been too strong for the Texans. General Kearney soon set ont for California, leaving Doniphan in comminul at Santa Fe, but the latter marched to (hihuahua, goo source of wealth being her fertik soil. The soils of Missonti are varicl in character and in a general way are of four different kinis. (Fig. I8.) The soils of the Ozark region are reddish clays internixed with gravel and lonse stones. Then the amount of stone and gravel is small enlivation of the soil is casy and gool crops are proluced.

The soil of all northern Missonri is a elay loam with a clay subsoil, both practically free from stones. It is black in color and extremely fertile. The land is rolling or gently undulating, making cultivation easy.

The snils of the western part of south Missouri are much like those of northern

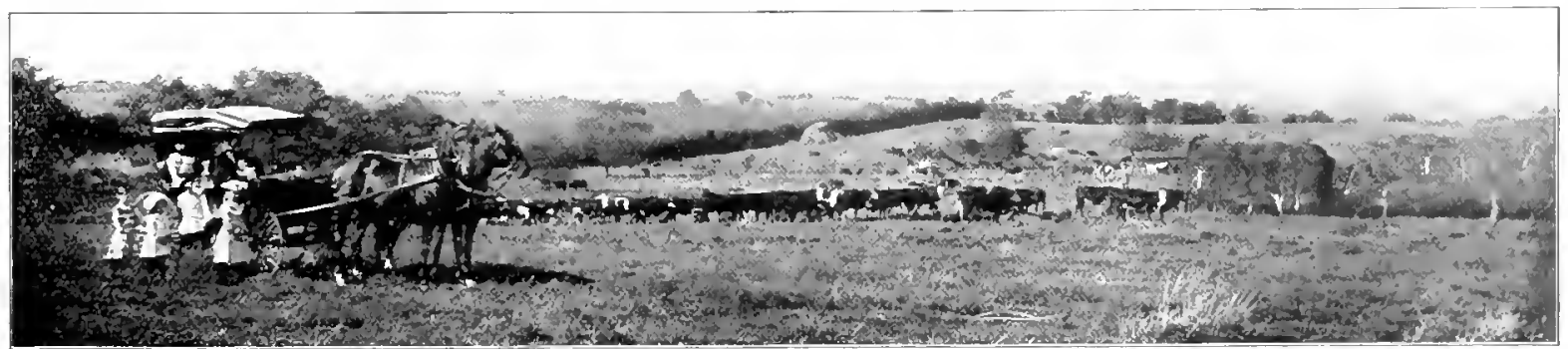

FIG.ro A farm secne in the high, rolling prairie region of northerestern Missouri. The lands of this section are highly fortile and here are somic of the largest stock farms in the state 


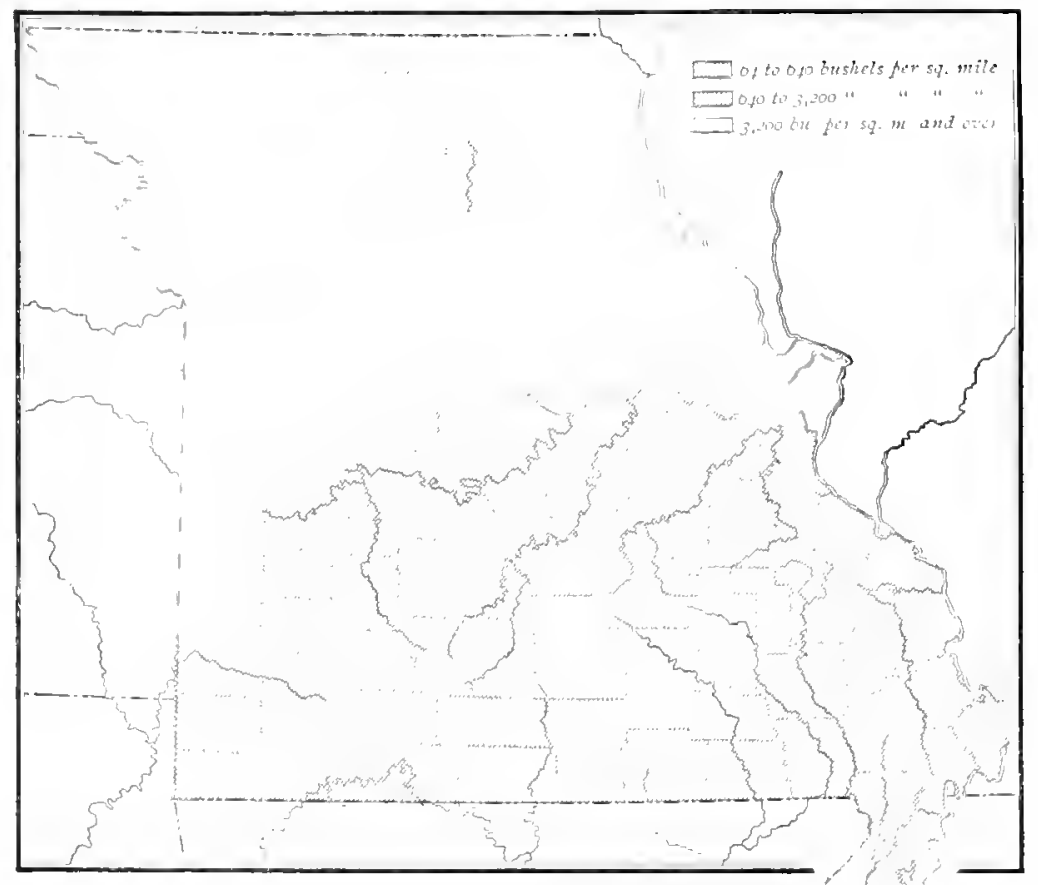

Frg. 20. The prudution of corn per sinare mile. acres of farm lands were deroted to corn, an acreage exceeding three times that planted to any other crop and enbracing more than one-half the area under all crops. The higlest yields are in the Missouri River basin and in the lowlands of the southeast. Flax, rye, broomeorn, clover seed, grass seed, and barley are profitally grown. Potatoes are an important farm prorluct, having a yearly value of more than $\$+, 000,000$, other vegetables vielding $\$ 5,500,000$ annuilly. (Fis. 27.)

Horticulture. Missouri stands ligh among the foremost horticultural states of the Union. A soil unexcelled for
Missouri. The surface is, as a rule, even more nearly level than that of northern Missouri.

The soils of the southeastern lowlands are sandy in the eastern half and eluyey in the western half of the region. They are very fertile, but the country being flat ancl its elevation how, a consir1cralle portion of the region is still unrler timber.

Throughout the state all cereals flourish, but corn is by far the nost valuable erop grown. Because of the extraordinary fertility of her soil and the favorable climate, onetenth of all the corn profluced in the United States is grorrn in Missonri. The value of her corn erop in 1903 was nearly $\$ 70,000,000$; wheat, \$ 5,000 ,000 ; hats, $\$ 5,500,000$; hay, $\$ 31,690,000$. (Tigs. 20, 21, 23, and 25.) In $1900,7,423,600$

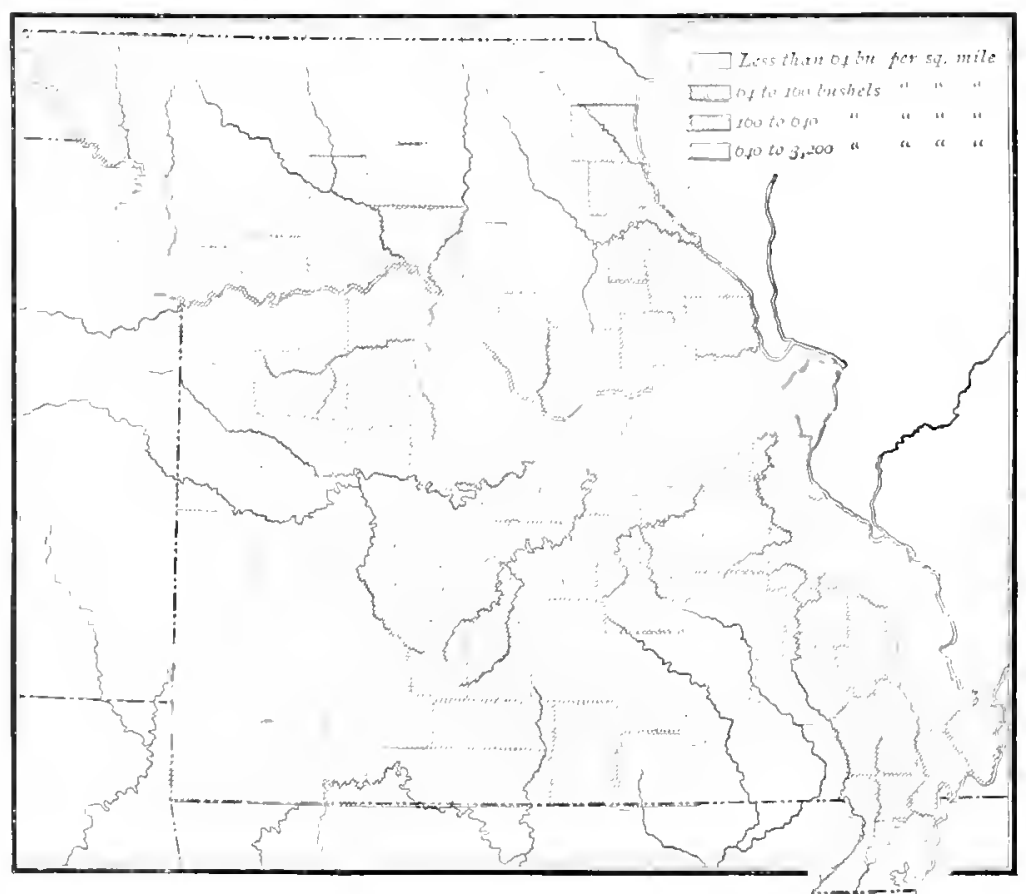

FIG, $2 \mathrm{x}$. The productwon of wheat fer square mile. fruit growing, and good water and drainage, as well as favnable atmosplacric conditions, insure liberal returns. There is not a county 


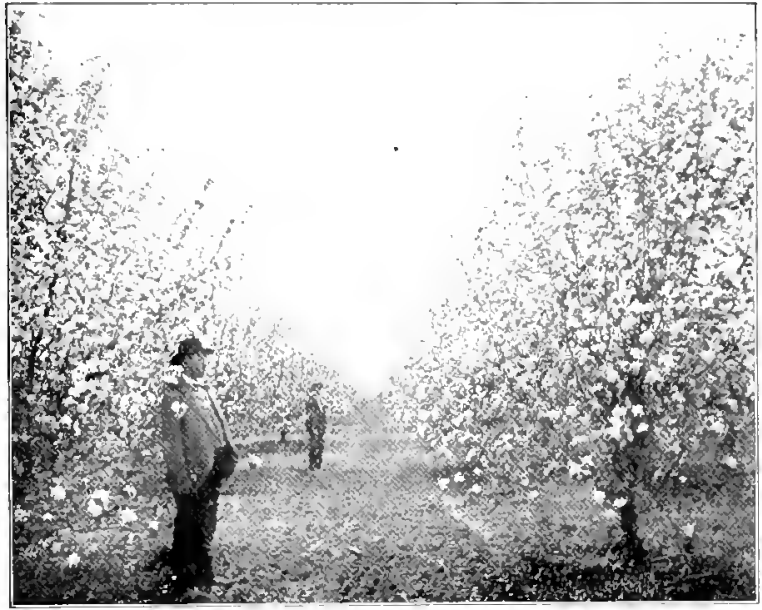

Fig. 22. An apple ordurd in Lafayette Comnty mblocm. Here along the Messomit Rater altere the liness soll is

of extracritiury fertility, are some of the largest and most productice apple ordhurds in the stetc.

in the state in which fruit cannot be suecessfully and profitably grown. The Ozark plateau and the locss region along the sreat rivers are especially adapted to oreharling. while southwest Missouri is famous for its small fruits. The state now has $25,000,000$ apple trees, and her orcharls and nurseries are among the largest in the wrlk. (ligs.

22 ancl 00.$)$

Missouri also ranks ligh as a grower of peaches, and her commercial orchards, some containing hundreels of thousands of trees, rank with the larerest in the courltry. Ozark peaclies are wirlely known for their sujeriority. (Fier. 24.) The trital yield of apples in I 900 was

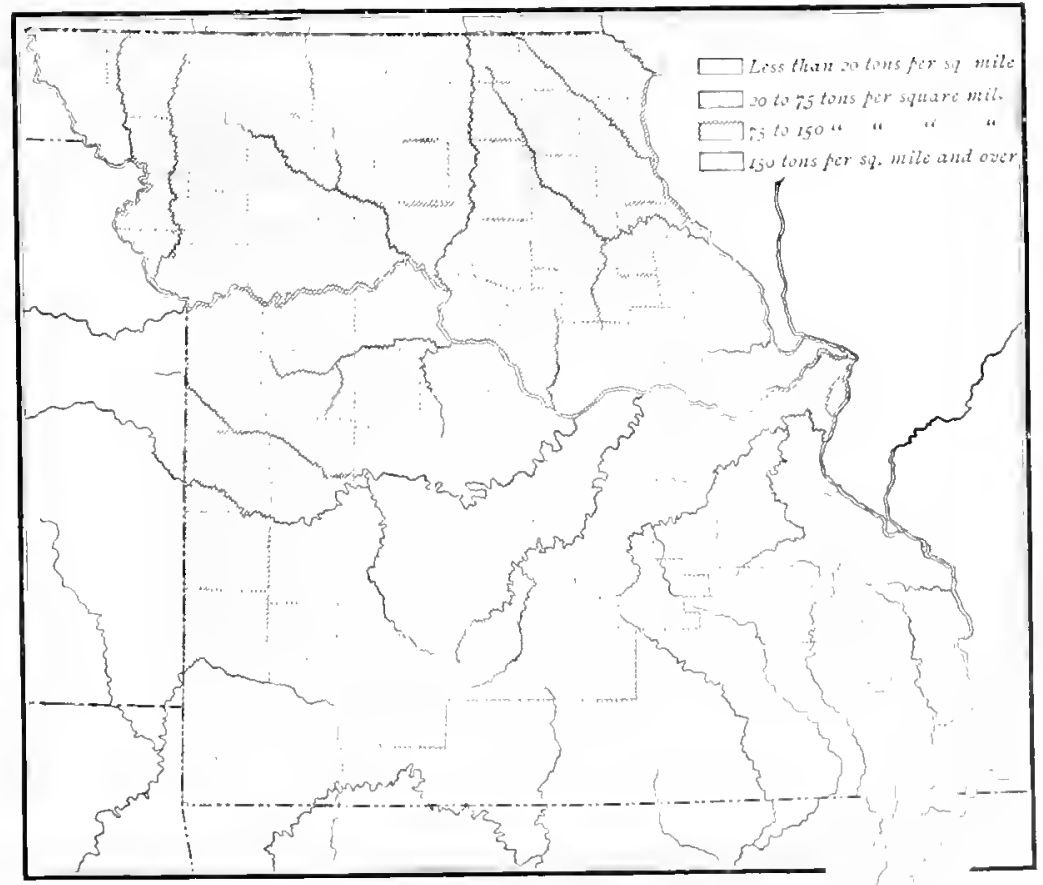

Fig. 23 The production of hay und forage per square milc. about $6,500,000$ hushels and of peaches $4,500,000$ bushels. Of her herry erop 13 . 000,000 quarts of strawberries and 5,000,000 quarts of blackberries formed the laresest items. Grapes are grown abundantly, especially on the hills. In I goo the value of the fruit crop in Missouri was $\$ 4,000,000$. (Fig. 26.) This sum has been increasel enor-

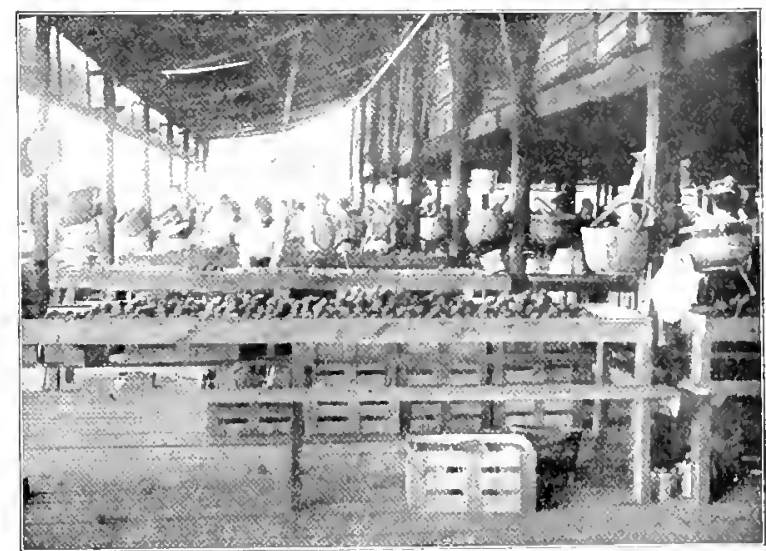

FIg. 24. Packing pathes for market, Koshkonong, Oregon Combl: Hertandure lends all industrus in this cuindy, which amtams the largest peach oritid in the state, the number of treas anceding roo,wor.

mously by the promlucts of latge areas uniler orelsards ant small fruits that have come intoluearing since that time. The State 11nrticultural Snciety, for nearly a half century, has llisseminated l:mowlendre on fruit cullture, ancl .llissonri, at Mrountain lirste, maintains the 
mly exclusive Fruit Experiment Station in the country.

Live Stock and Dairying. Missouri is one of the foremost live-stoek states in the Union. This is due not only to her fertile, well watered pastures, the large quantities of grain and forage grown, and a highty favorable climate, hut likerrise to the fact that the state is surrounded on all sirles by good markets for her surplus promucts. Exclusive of barns anu other equipment, the livestock interest was vałuel in 190,3 at $\$ 200,000,000$, the state heing excelled only by Texas. Illinois, Iowa, and Kansas. Missouri stoek is of high grate. and every important hreed is

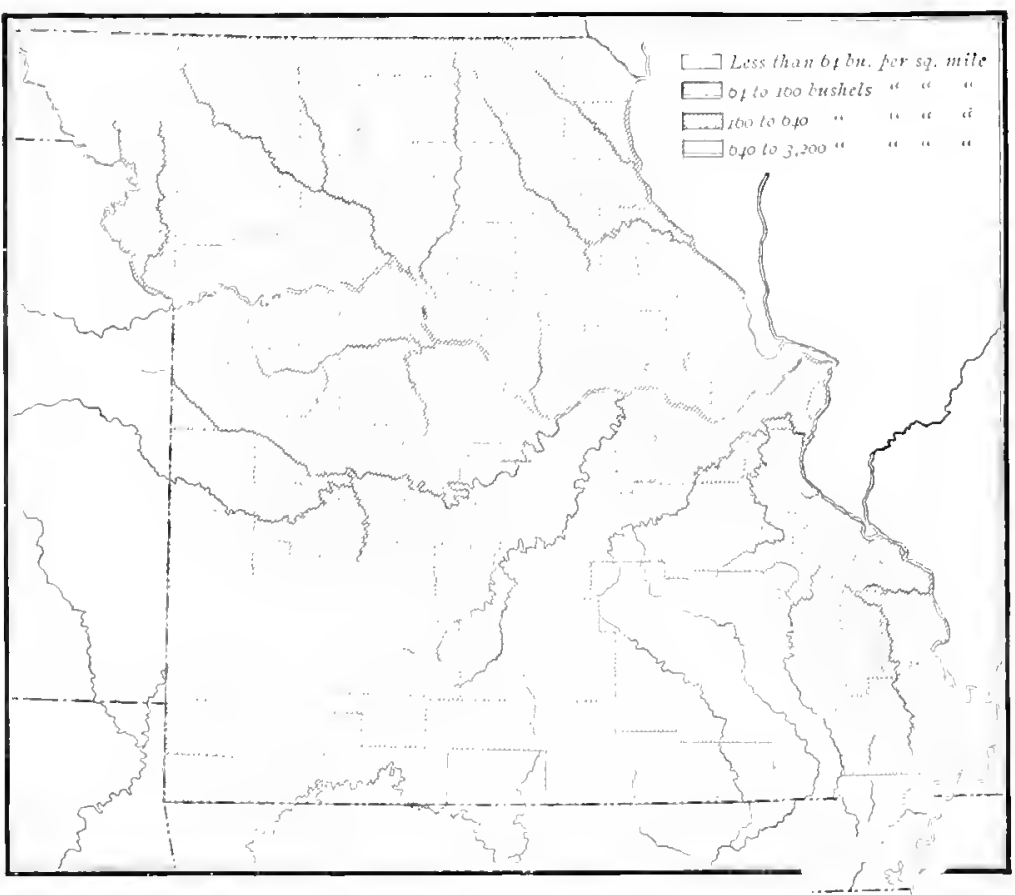

Fig. 25. The produtum if eats fer square mile. represented in her herds. The great extent of well watered grazing lands and the large grain crops eneourage alike the breding of

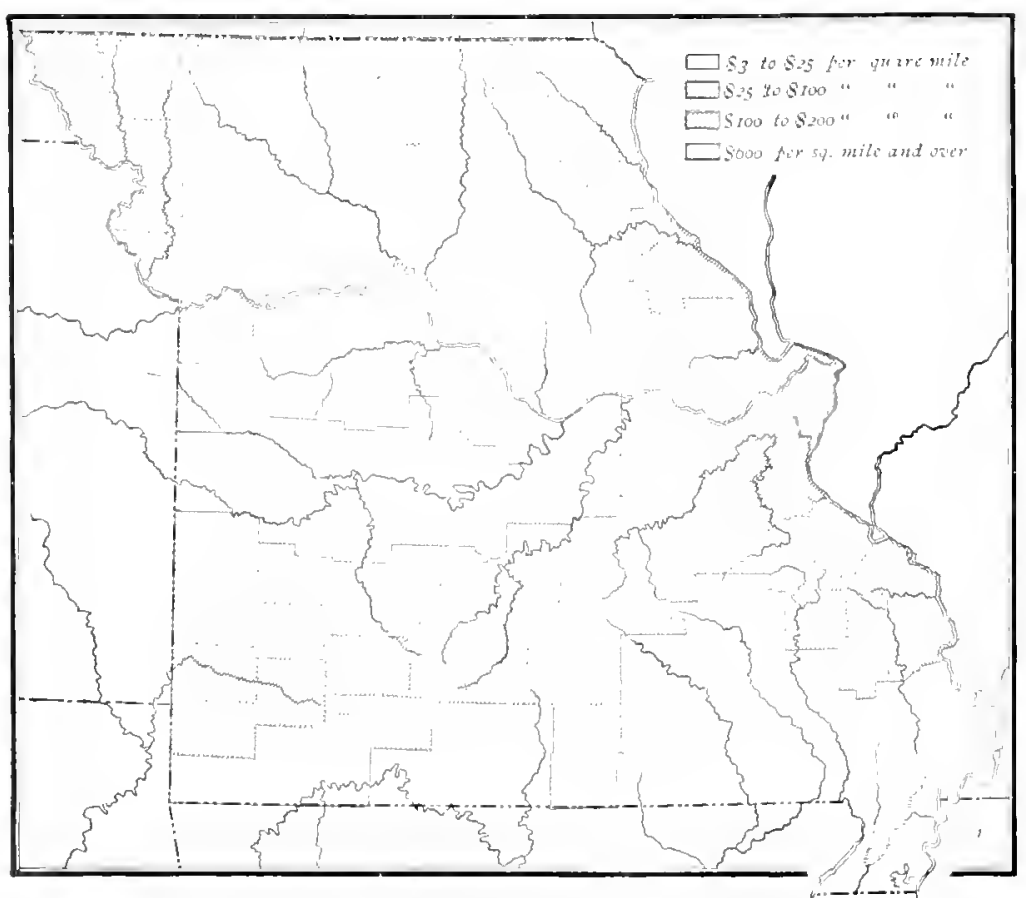

Fig. 26. The i'ulue of frut per siquare mile. cattle, horses, and hogs. Missouri, with 3,060,000 cattle and more than 1,000,000 hrorses, stands among the leading cattle and horse states. (Figs. 20, 30, and 32.) It is surpassed only by Iowa and Illinois in the number of its hogs, of which there are in the state nearly 5,000,000. (Figs. 28 and 3I.) Intes that are widely known for their superiority are bred largely for shipment and Texas alone rivals Missouri in numbers. (Fig. 20.) There are to-day, i 905 , about one million sheep in the state. In Missouri the breeding of Angnra goats has attracted considerable attention and the industry has been sucessfully cstablished in a number of localities. (Fig. 3.3.) With a total of 157,472 , Missouri has more live-stock farms than any other state in 
the Union. The average annual yiekl from these farms is $\$ 6.86$ per acre, while the average for the whole Uniterl States is hut \$5. I 2 per acre.

Dairying is one of the most lucrative rlivisions of the livestock industry. There are in the state more than 750,000 dairy cows which yicld ammually nearly 260,000,000 gallons of milk, the total value of the dairy proclucts being afout \$5,000,000. The Missumi State Dairy Association and the dairy work done at the State Agricultural College have aided greatly in the development of the inclustry. Plants yielding food for the honeybee abound, and Missouri, with an

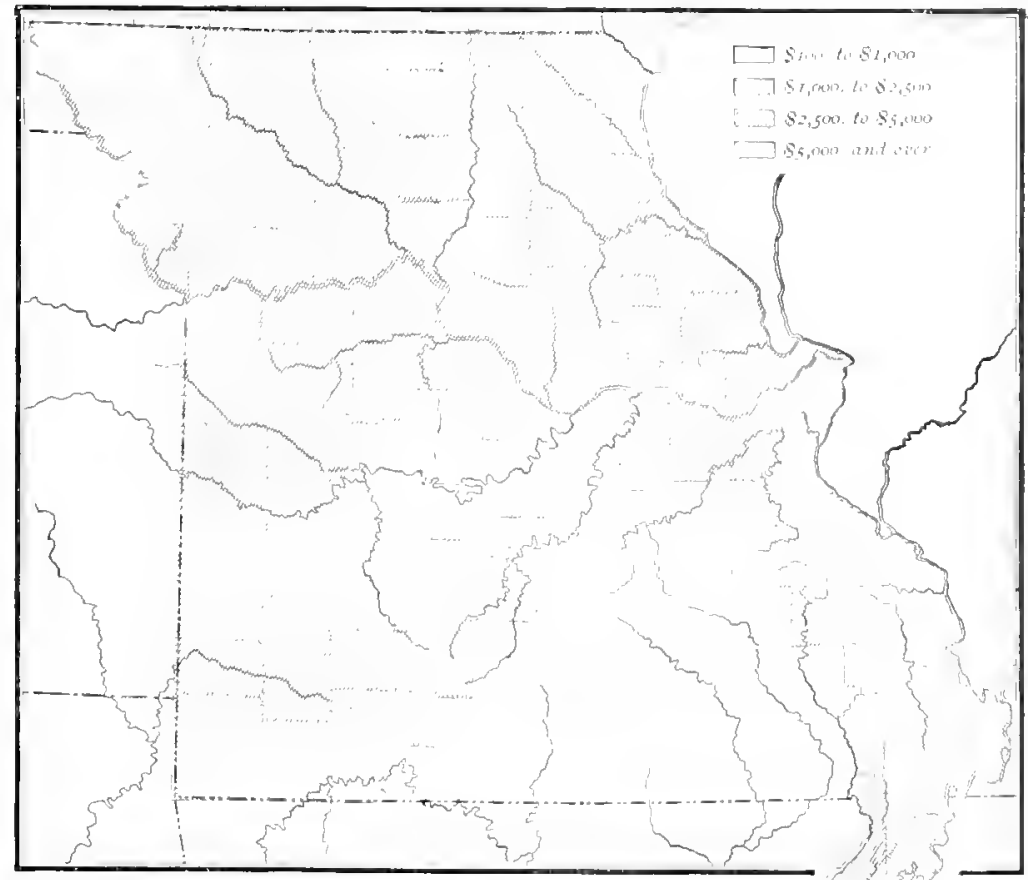

F1G. 27. The inalue of farm producis per square mile. annual product of more than $3,000,000$ tions are si favralile and grain production pounds of loney, ranks third in production. so large poultry is sure to flomisli. 1Innee

Poultry Raising. Where natural condi- this is an important and rapidy growing in-

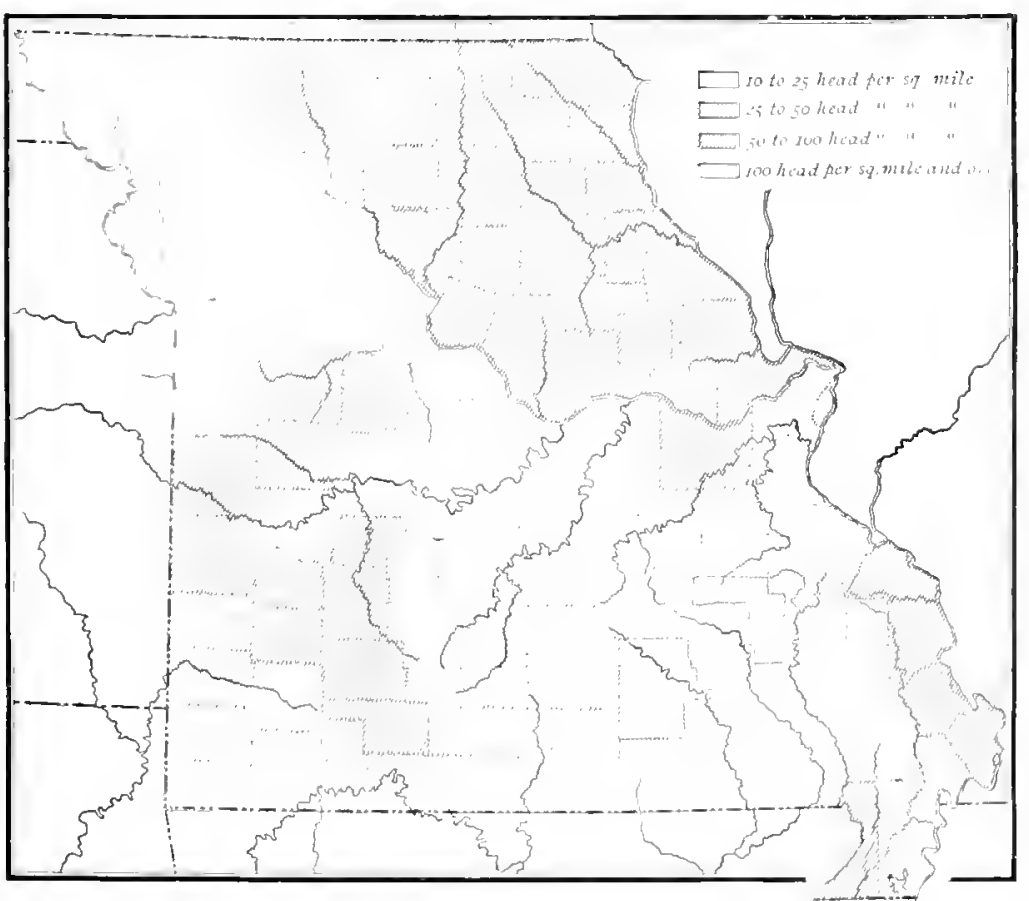

Fig. 28 The distribution of hogs per square mile dustry, and one in which Nissuri leads the country. There are in the state letween fifteen and twenty million clickins, at last 500,000 turkeys, as many reese, and 300,000 ducks. The value of the poultry prot ucts for the year is alout $\$ 1 S$, $\infty, 00,00$. (Fig. i.t.)

Mineral Resources. Missouri has a wealth of mineral resources. The chief minerals are loal, zinc, and coal. The kad and zinc nines are all in the Ozark region, in three districts -the southeastem, the central, and the southwestern -in which either one or both ores are mined. (Firs. 37.)

The sontheastern, which is the largest of these districts, lies 
in St. François, Marlison, Washington, Franklin, and Jeffersm counties. Lead is the only ore miner in this district. At the present time most of the lead ore comes from St. François and Madison counties. The ore nccurs as little lumps and specks scattered through solid limestone rock. Fur this reason it is called dissominutal ore. It is founcl in mines from 200 to 500 feet beneatl the surface. The rock containing the ore is blasted out, raised to the surface, and crushed almost to a powrler It is then carried by running water through a great many boxes. This process washes away the lighter limestone pieces, learing finally

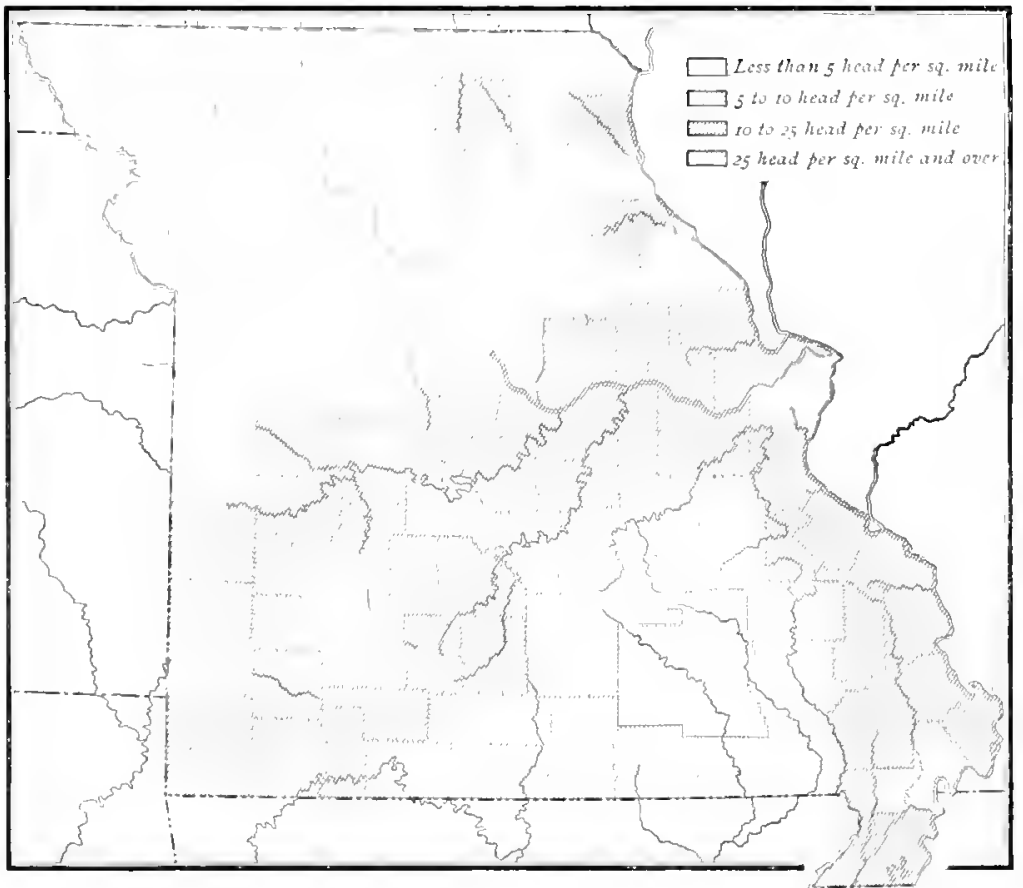

FIG. 2n The distribution of horses, mules, und asses per square male.

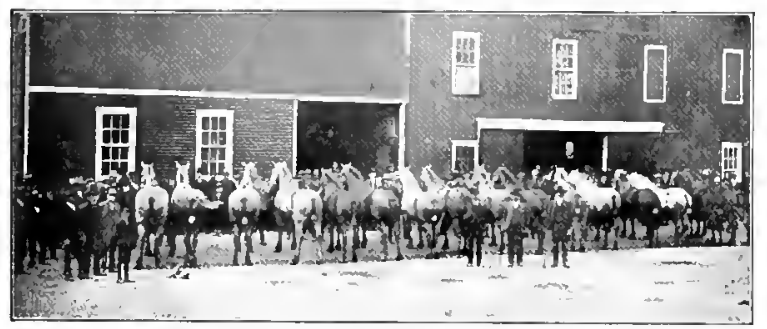

Fig. 30. Secne at a horse morket, Kanus city. Missonri is an importunt senter forthorses. One of the four purchasing stations for Goternnont horses is locuted at Kansus City' and another is at St. Lous?.

only the clean, havy learl ure, which is as fine as sand and clay. This is shipperl out in canvas bags.

The central leat and zinc district lies in Moniteau, Cole, Miller, Horoan, and C'anden counties. ()nce a sreat deal of ore was mined here, but now only a few small mines are running. The lirgest of these mines is at Furtuna, near the line hetween Morgan and Moniteau counties. The ore in this district occurs in pockets in clay and in broken pieces of rock. Mlost of the mines are shallow.

The southwestern lead and zinc district, which includes Jasper, Newton, Lawrence, and Greenc countics, is very rich. It is the richest zinc region in the country, yielding about four-fifths of all the zine ore produced in the United States. The producing mines lie chicfly in Jasper, Newton, and Lawrence countics. (Fig. 36.) Small amounts of lead and zine ore have been mined in Barry, Stone, Christian, Timey, and Dade counties.

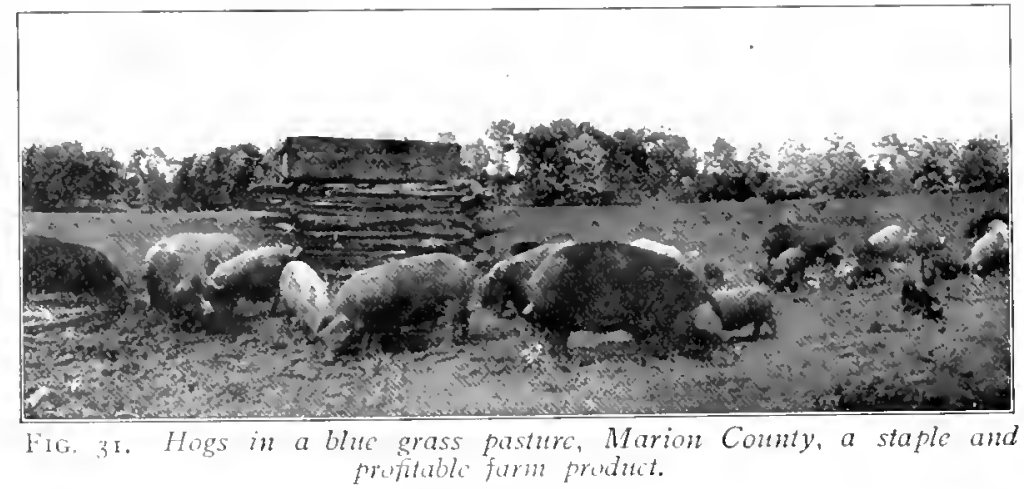




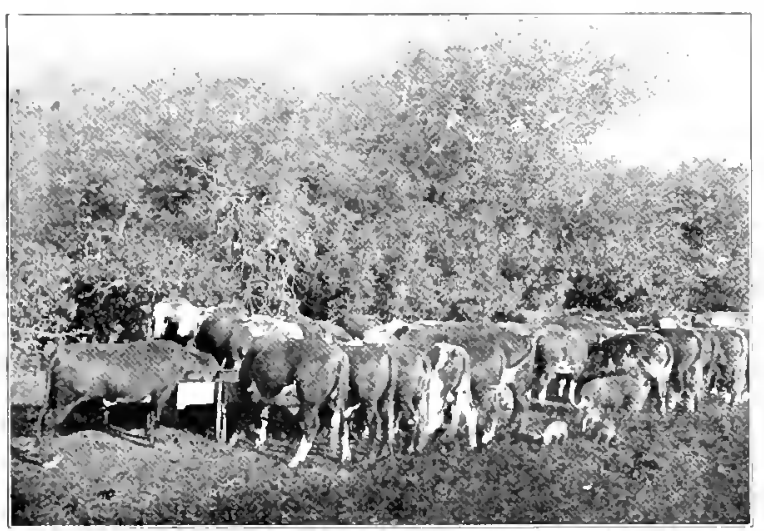

Fir. 32. Senc on a Missontri stock farm. Last fecd on the farm before guing to markit.

The mines in Jasper, Newton, and Lawrence counties are, as a rule, not so deep as those in the southeastern district. (Fig. 35.) The ore occurs usually in open ground, not in solid roek. In some mines it is found in layers between the leds of rock, botin kat and zine being found in the same mine. When the mines were first worled there was no demand for the zine ore, so it was thrown aside and not used. When a lemand arose for it this ore was collecterl and sold. and now zine ore constitutes the principal product of the mines.

Several years agn southern Missouri harl a great many iron mines and iron furnaces and was an important irom prolucer. Now the only furnace in the state smelting Missouri iron ores is one in Dent County. This is hecause the famous old jron mines, like Iron Mountain, Piket Knob, and Simmons IIountain, have beenmeexhauster1, and no new paying mines have been discovered.
Copper acurs in in number of countios.

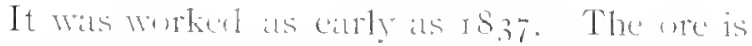
now minerl and smelterl at Sullivan, and Iteposits at other pointsare attructing attention.

The ond fickls of Missouri axemes at frelt

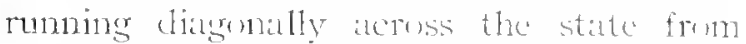
northeast te southwest. The eastem line of this lect cxtemis rather irreyrularty from the northwestem corner of Jasper County to lilasgow; thence it extenels neitrly southcastware to fintem and then northwarl to Limeaster. The western bumeliry of the belt extends rerv irrogularly from the southwestern part of Bates County northeastward, meeting the state line in l'utman Connty. West of the bolt included between these two

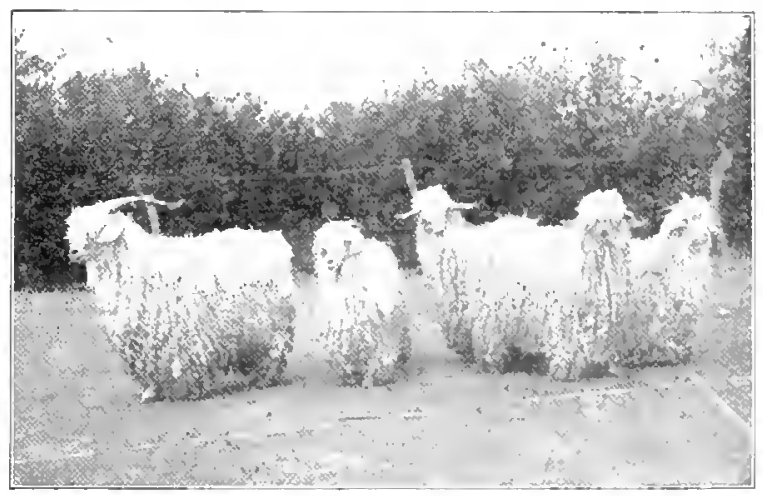

Fig. 33. A croup of prize thoma goats. The aw

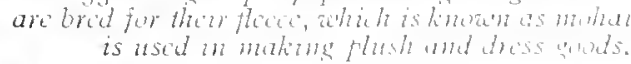

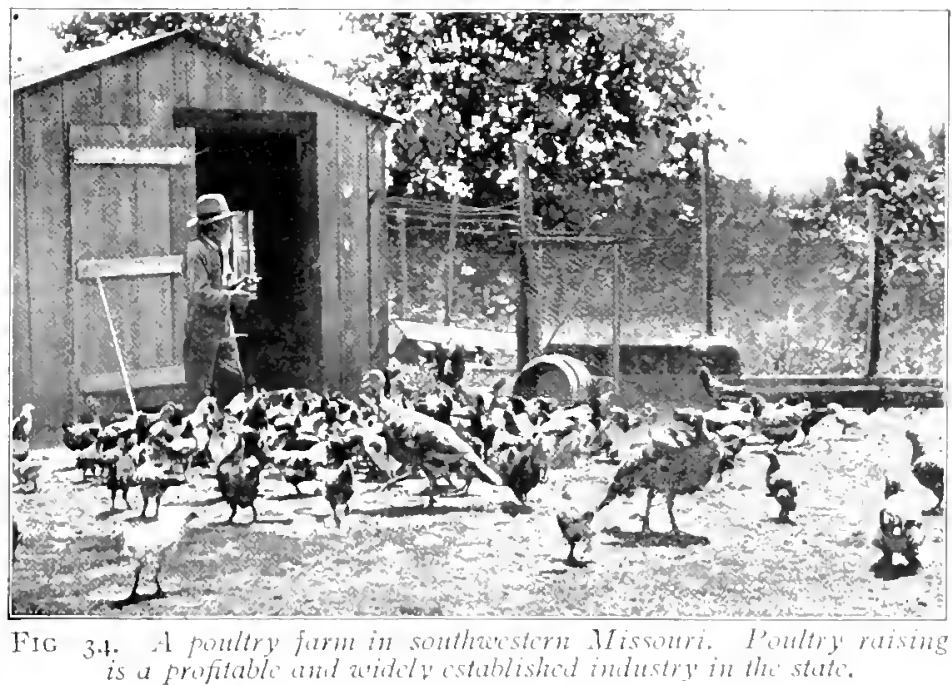

lines a few mines (xist, but cast of it there are no mines of any importance.

Within this belt there are three coul-mining areas, which we shall call the southwestern, the centrit, ant the nurthern regions. The center of the 


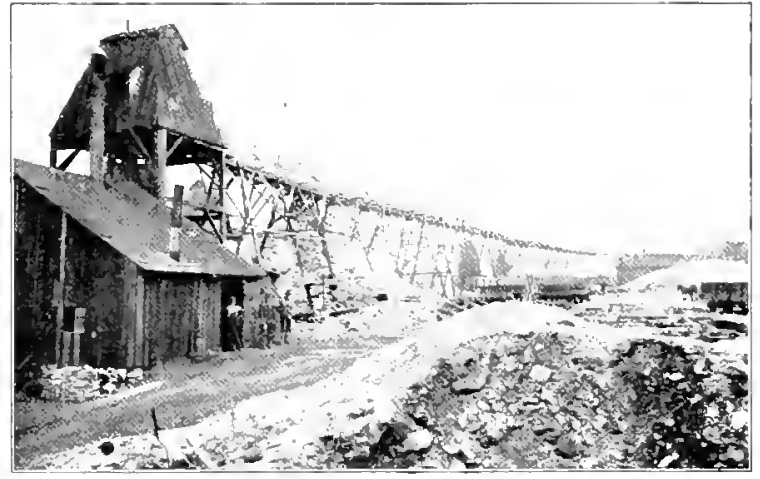

Fic, 35. Mining sene at Atrora, a busv lead and ainc minme torn in Lazrence Camly, one of the inportant mineral enuntios of the state

sonthwestern region is Rich Hill, that of the central, Lexington, while the northern and larger region has sereral important centers. among which are Iruntsrille, Bevier, Novinger, and Menclota.

The coal herls embraced in the southwestern rogion are about two and one-half fect thick, in the central region they are about one and three-fourths feet thick, and in the northern region the becls are from about two and one-half to frve feet thick. (Fig. 37.)

The coal product of Missouri is an in portant one, and her resources are such that her coal-nining industry will continue to exist for a long time. Up to the present time the marl:et for Missouri coal has licen west of the mining resion. Manufacturing. Manufacturing is an industry confined chicfly to cities and towns, and its success depenils upon the presence of raw materials near at hand, cheap and abun dant fuel and food, and good transportation facilities. In all these things no other commonwealth excels Missouri, which leads all

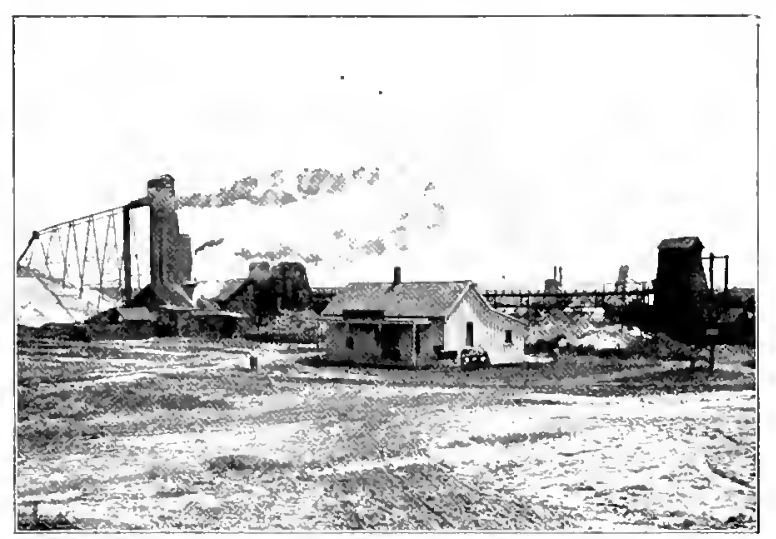

Fig. 36. At mine in the sonthatestern leal and sine district. The zin ores of this distrit are abdely funen for the ir richness and it is one of the world's chicf sources of supply for zinc.

states west of the Mississippi and ranks fifth in the Union in manufactures. (Fig. +2.) St. Louis, the fourth city in size in the United
Fig. 37. The distribution of lead, zinc, and coal.

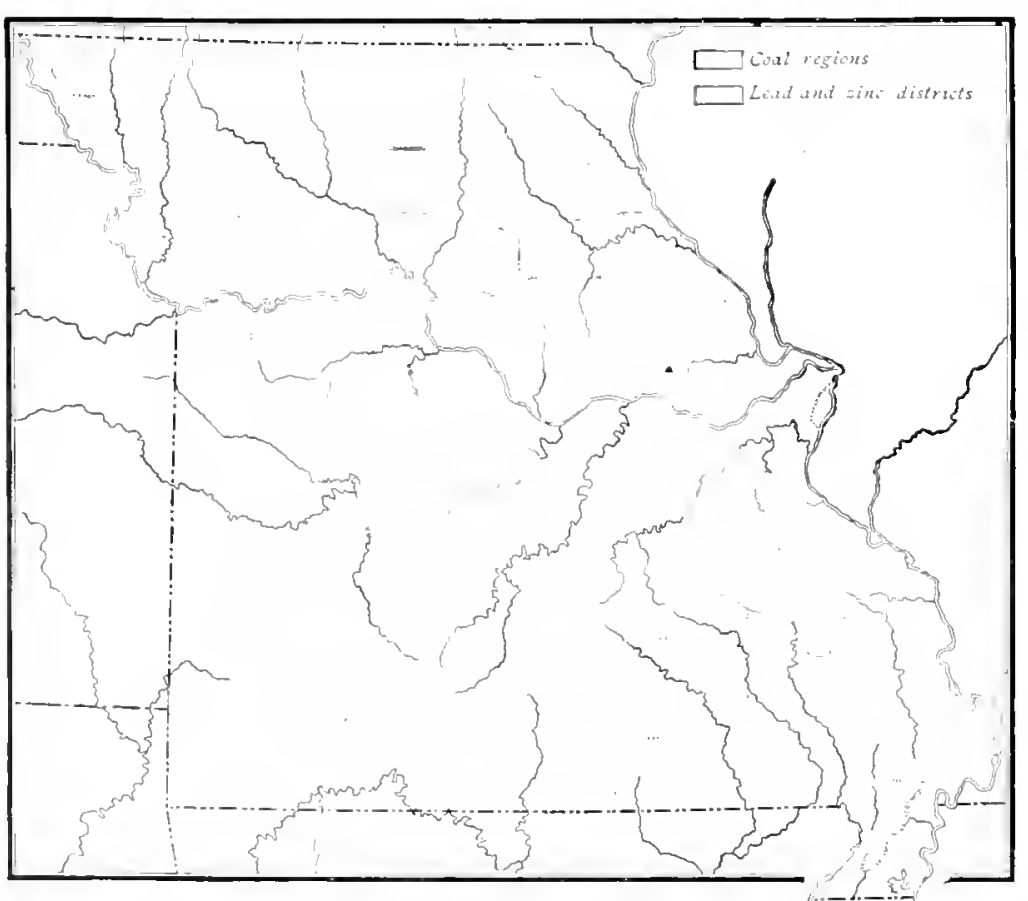
States, is likewise fourth in manufacturing, prolucing 111 I 900 goods amounting to $\$ 233,000,000$. In the manufacturc of some things, such as tobacco and boots and shocs, St. Louis has few if any rivals; Kansas City, second in population in the state, has a yearly product va $1 \mathrm{u}$ ed at 
$\$ 36,000,000$; St. Joseph, the third city, annually manufactures profluets worth $\$ 3 \mathrm{I},-$ $\infty 00,000$; Springfield, the fourth eity, has for its leading industry the manufacture of flouring and gristmill products. (Figs. 43 and +4.$)$ While there are 250 kinds of manufactures in the state, the principal

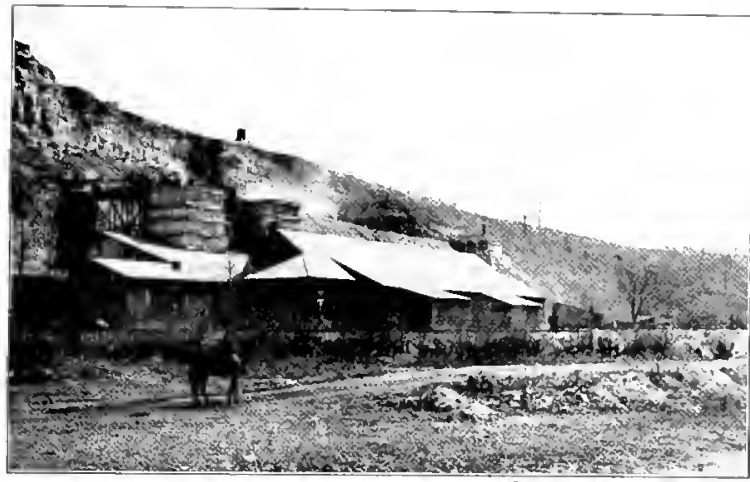

Fig. ${ }_{3}$ S. Lime works in Marion Connty. Valuablo deposits of suitable stome and shale have made this county one of the thief conters of production for lime and Portland centent. efficient neatrof of transportation are necessary for communication and for carrying on trade. The Mississippi and Missoniri rivers were in early days the jurincipal channels of travel and traffic, but witl the lunkling of railroads a better means of transportation was offered, and the rivers produets, in the orler of their capital value, are malt liquors, fonndry and machine shop, and flouring and gristmill prorlucts, lumber and timber, printing and publishing products, tobace, slaughtering and meat-packing supplies, men's chthing, brick and tile, railroat cars, boots and shoes, carriages and wagons. (Figs. 39, $+1,45$, and $4^{6}$.) Inexhaustille deposits of excellent lime rock and fine sand have made profitable the minor industries of making lime, glass, and cement. (Figs. I I, $3^{8}$, and 40.)

Transportation. The derelopment of a country depends largely upon its facilities for transportation. Good roads or other

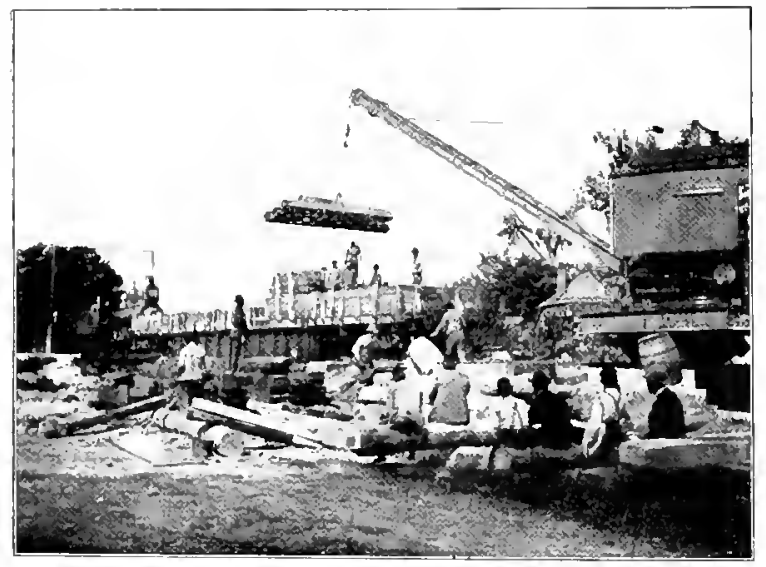

FIG. 39. Loading railroad ties for shipment. Ties are a leading product in lumber distrits conernicut to transportation and an important item in the trade of the neurby toans. have lost their suprenacy. River traffe, however, between St. Lontis and the rulf is still large. (Figr 47.) Thestate is traversed in all directions by railroals, the chief centers being St. Louis, Kansas City, andl St. Jostph. In 1860 there were $S_{1}$; nules of railmad in Missouri. By a $8 S 0$ this mileage had grown to 3,960 , and to-day cxeveds 7,700 miles.

Banks. Banlis are a necessary factor in industrial life, and Missouri learls in the num number of national banks. The reposit per capita of the citizens is $\$_{I}, 3 S . S_{1}$.

The State Government. The first constitution was adopted in 1820 , and, as the state

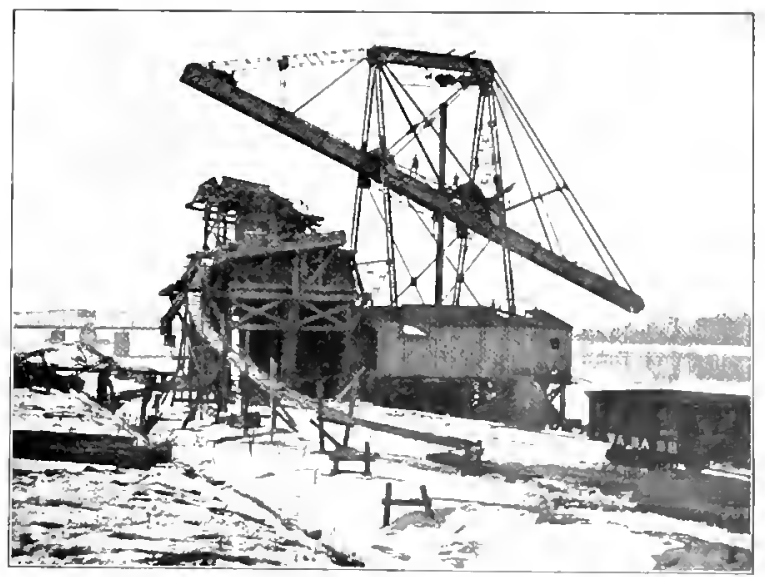

Fig. 4o. A sand dredge at work. Sands aluable for glass making and for bualding purposes are whidy distributed in hlissour and are utilized largely in these industries. ber of state hanks and is serenteently in the 


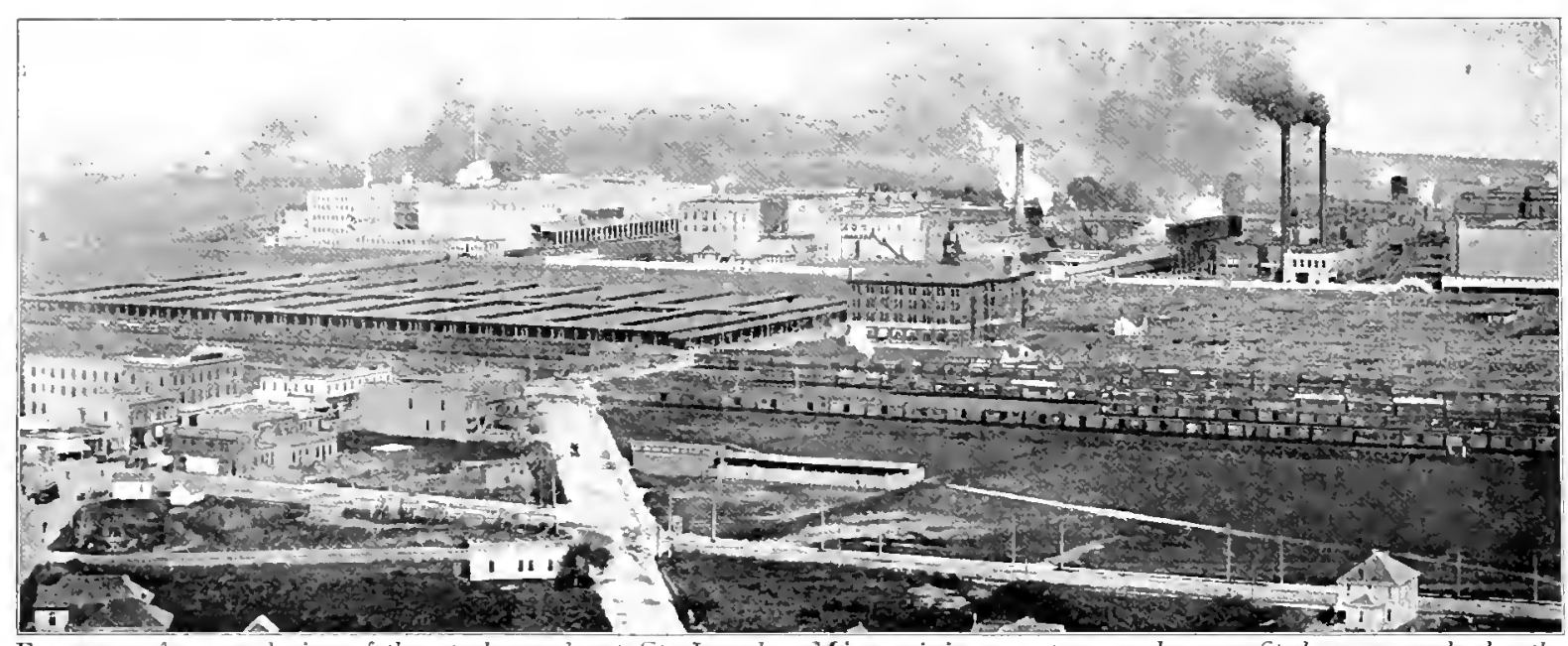

Fig. 4I. A gencral the of the stock yards at St. Joscpll. Missomeri in recent years has frofited enormously by the stcady trond of the slanghtoring and meat-packing industry toward the corn folt and the cattle

comtry, and by rooo it had become the leading industry in the state.

developed, another better arlapted to the neetls of the citizens was adopted in 1865 . The present constitution was adopted in 1875 .

The government is liviled into three parts the Executive, the Legislative, and the Jurlicial. The Executive consists of the Govemor, Lieutenant-Governor, Secretary of State, State inditor, State Treasurer,

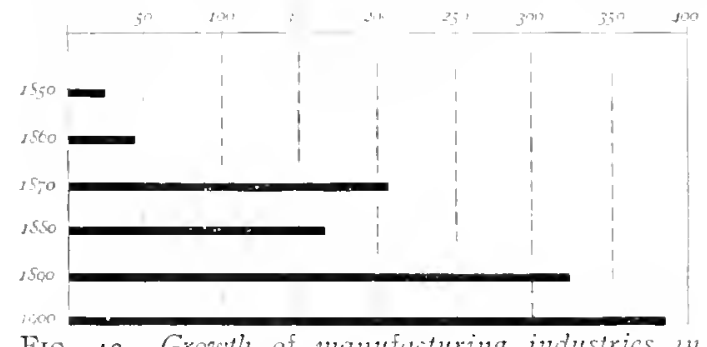

PIG. 42. Grondth of manufuturing industrics in Missourt, shan br poluc of poducts, in millons

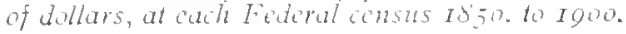

Attomey-General, iml Superintendent of Putilic Schorls, all of whom are elected by the people for terms of four years.

It is the duty of the Governor to see that the lams are faithfully executed. He is commantler-in-chief of the nilitia. Ile may grant commutations, reprieves, and pardons, and appoint many officials with the consent of the Senite. The Lieutemant-Governor is ex-officio Presilent of the Senate, ant he succeeds the Governor in case of death, disat)ility, or remoral from office. The State Treasurer receives and keeps the money of the state and pays it out on warrants

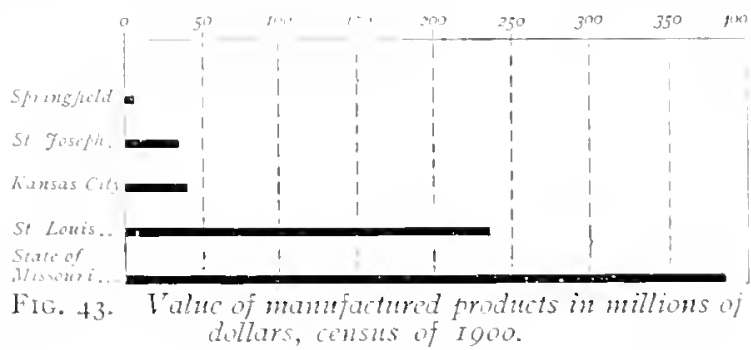

drawn upon the treasury. The State Auditor leeps the state accounts and enforees the payment of all cliims lue the state.

The clice souree of the state revenue is the general property tax. A State Board of Equalization, consisting of the Governor, State Aulitor, State Treasurer, Secretary of State, and Attorney-General, adjusts and

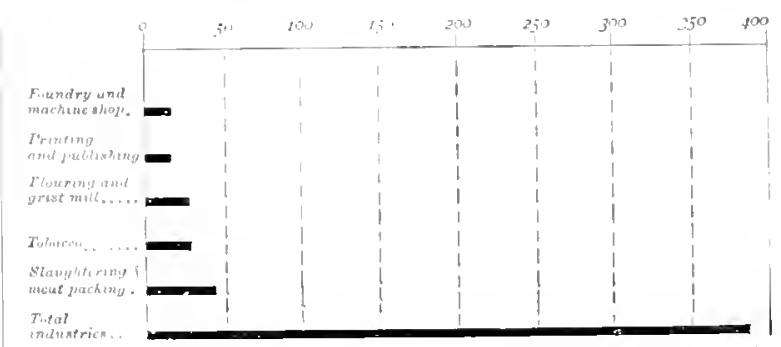

Fig. +4. Valuc of spicial mantefactured produts in millions of dollars, in .Hissonri, in 1900. 


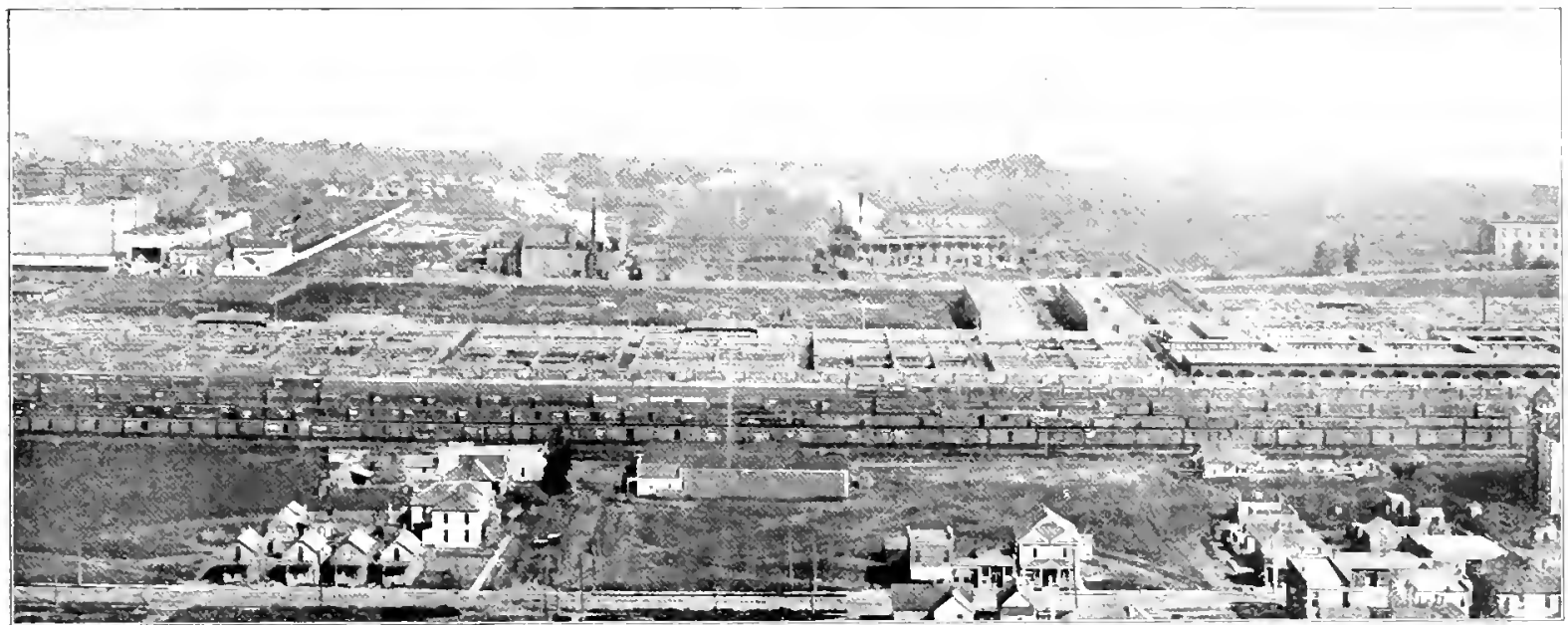

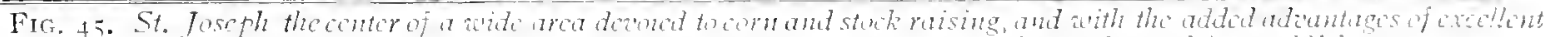

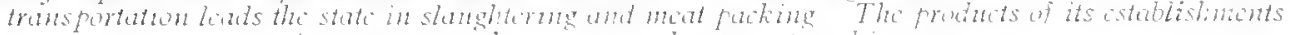

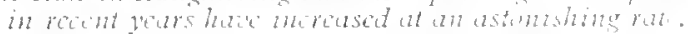

equalizes valuations among the several erountics. This Boarl also assesses the property of rithoral, telegraph, telephone, and bridge compranies

The Sectetary of State has charge of the public recoris and acts of the Gencril Issembly, and is custodian of the state sail, is registrar of lankls, and superintends the examinations of state hanks and trust companies. The Attorney-Gencral is prosecuting attorney and clice legen arliser for the state. The State Superintenilent of

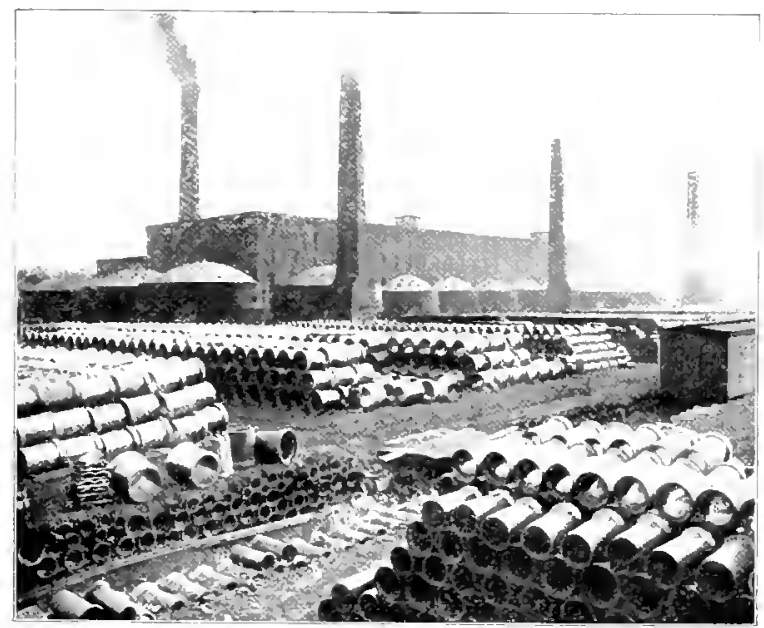

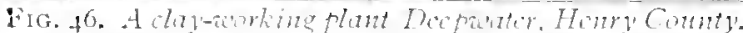

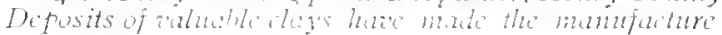

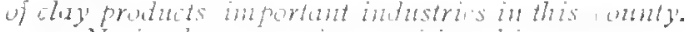
Nothe the seare pipo uariting shipment.
Suhools directs the puldie schools of the state, excreises supervision wer the schond funls, and nay grant cortificates to teathers.

In aldition to the oflicers alreaty namel, there are railroul commissiomers who are elected by the people, and rarious other

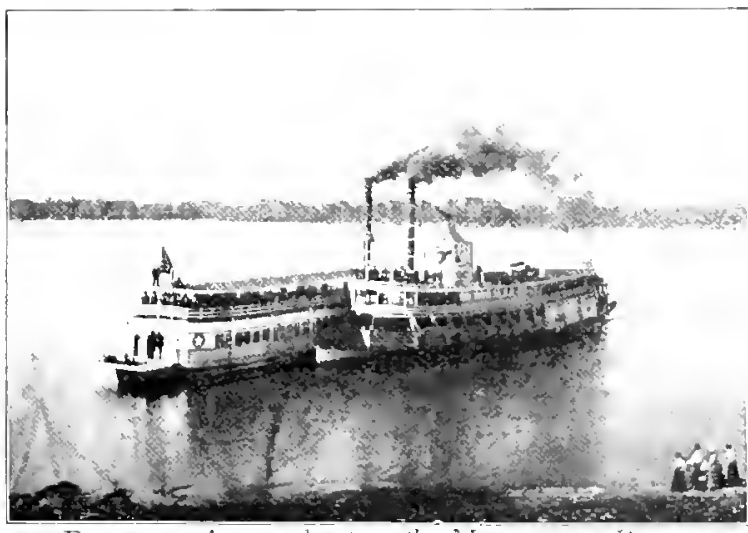

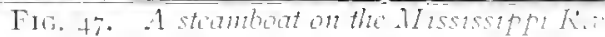

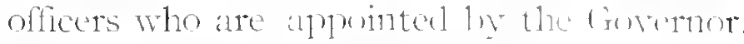
Annong the list nentioned are the deljutintGeneral, Sulerintenklent of Instrianec, Cirittors of the Lniversity, Revents of Nommal Schools, and Bonm of Manigers of the state charitalle and penal institutions.

Each cotnty deets ufficers to administer the local government. The hishest wficer in the connty is the sheriff. The prosecuting 
attorncy in each county represents the state in criminal prosecut.int and is legal adriset for his county. A constalle is elected in cach township, and police officers are appointed in tomns and cities. The local government of citios a $12 \mathrm{~d}$ tomin $\mathrm{s}$ consists of a major and rollncil or

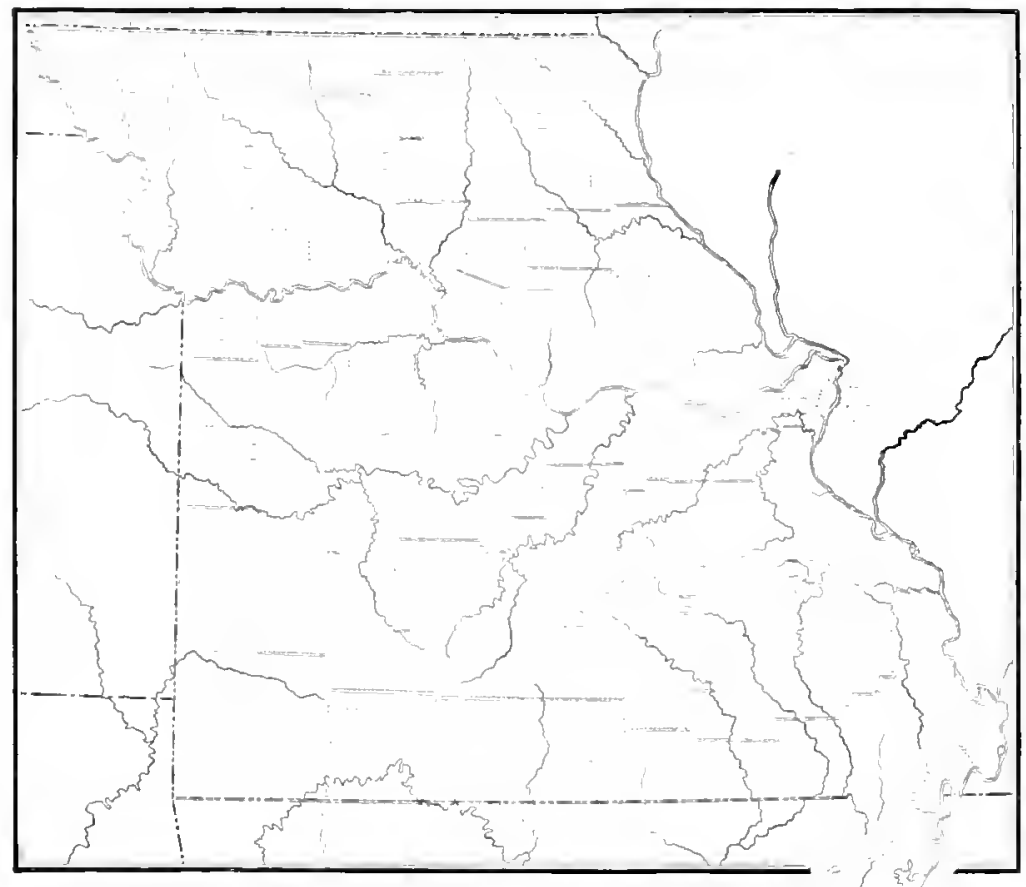

FIG. 4S. The congressional distrits of Missouri, Igo4 circuit courts, C $\mathrm{I}$ i $\mathrm{ml}$ i 11 a 1 courts, county courts, p10bate courts, and justice courts. Their purpose is the cuforcement and aclministration of law. The Supreme Court is composed of seven judges, each of whom is electerl for ten years at a salary of $\$+, 500$ per yrats.

board of aliermen, city attorney, treasurer, auditor or comptruller, and police officers.

The legislative or lawmaking mower is rester in the remeral Issembly, which meets in Jefferson City every two years. (Fig. 65.) Its memlers are elected by the people, anil at present number thirty-four Senators, elected for four years, and I I $^{2}$ Representatives, clecterl for two years. (Fig. + 8 .)

The judicial department consists of : Supreme Court, courts of appeal,

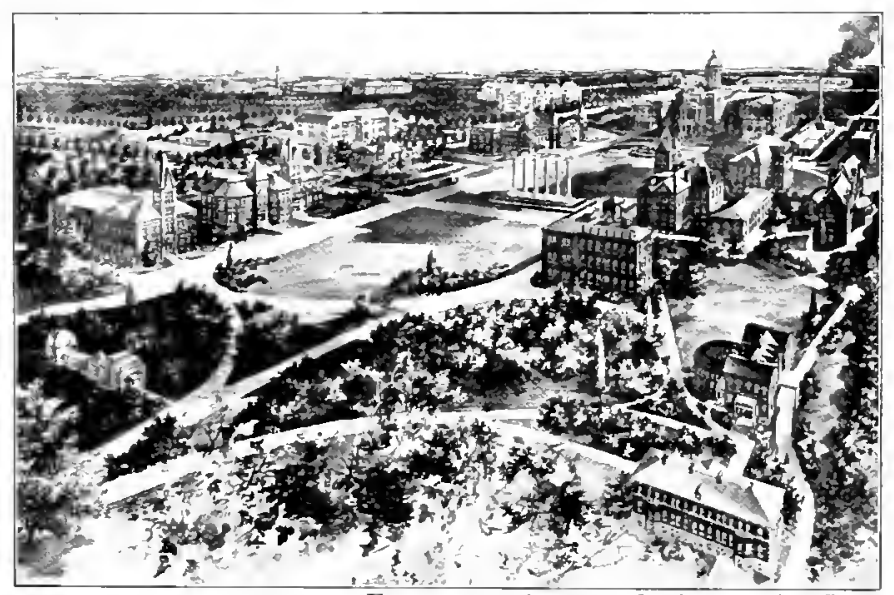

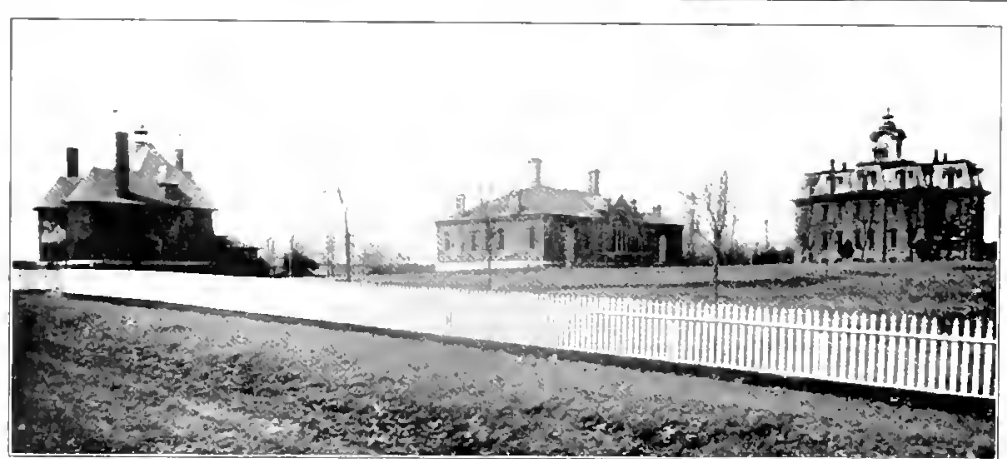

FIG. 49. The Selrool of Mines at Rolla.
FIG. 50. A general ricut of the State

Penal Institutions. There is a penitentiary for both men and women located at Jefferson City, a state Training School for Boys at Boonville, and a state Industrial Home for Girls at Chillicothe.

State Charities. There is a school for the blind in St. Louis, 
a school for the deaf andilumb at Fulton, and the Missouri Colony for Feeble Minuled and Epileptics at Marshall. Missouri has four state liospitals for the insane, located respectively at St. Joseph, Fulton, Farmington, and Nevada. There is a Feleral Soldiers' Home situater at St. James, and

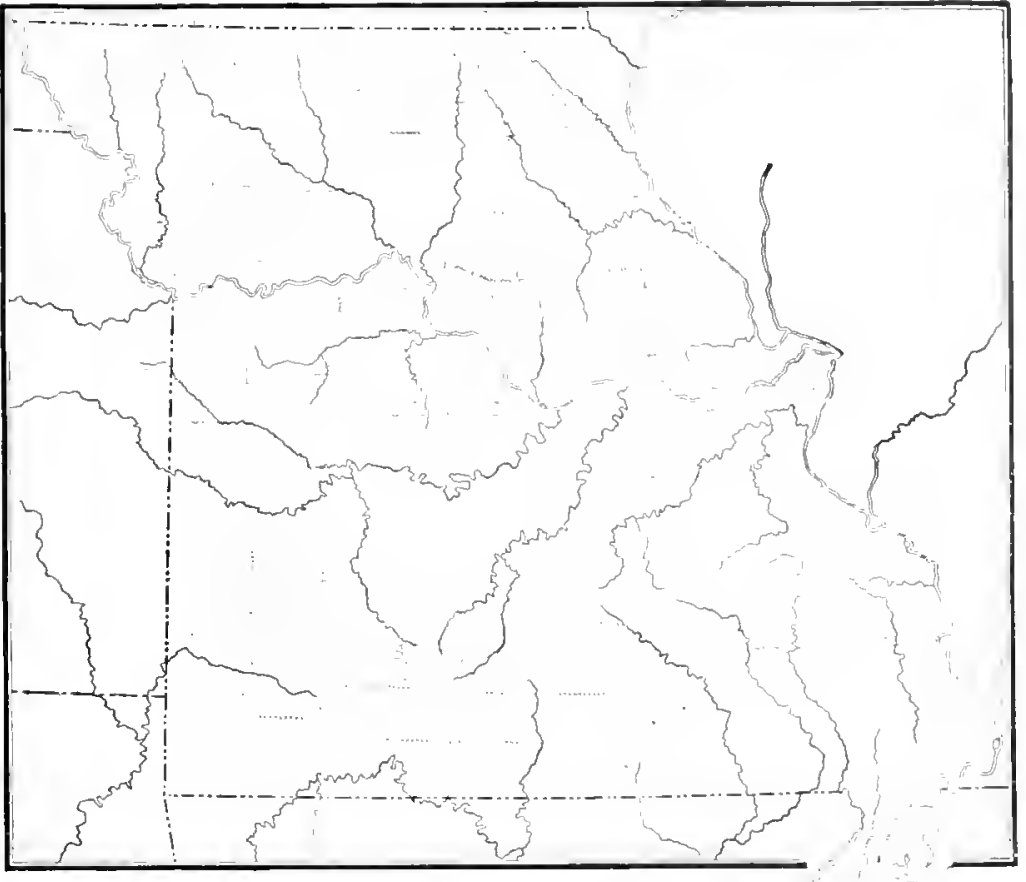

Fig. 5I. The locution of the ladeling educational institutions of Missonrt.
Boone Count stancls at the heiul and is the ontgrowth of the pullic schuol system. It has seren we11 erpuiprer] departments, with an annutial attendance of about 1,700. (Fig. 50.) It Rolla is the Sehoriof Mines at 11 lleta $1-$ lurgy, a de. partment of the State Lniversity and in outgrowtl if a Confederate Sulliers' Home at Higginsville.

Education. Missouri carly male liberal provision for public scluons and to-rlay has a permanent prorluetive school funcl that exceds Si 3,000,000. The first constitution not only made ample provision for schorls, lout likewise called the attention of the Legislature to the need of a state university; the second constitution repeated and emplatsized the statements of the first. The arowth of the pullic school system has been rapit and sulostantial, and the per cent of illiterates in Missouri has decreased steadily. The State University, founded in $183+$ at Columbia, the mining interests of the state. (Fig. 4\%.)

There are six nomal schonls. The oldest, founded in $186 \%$, is at Kirlisville (Fis. 5.3); the others are located at Warrensburg (Fig. 52), Cape Girarteau (Fig. 5.4), Springfield, Maryville, and at Jefferson City, where is located Lincoln Institute, for the training of colored teachers. About 3,000 stulcuts are in attendance annually at the normals.

The State Boarl of Education is empuser of the State Superintendent of Pullic Sclum ls, the Governor, the Secretary of State, ind the Attorney-General. The state has schem property worth $\$+2,600,000$, an emollment if

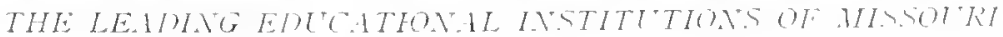

COLLEGES AND LNITERSITIES

1 Southwest Baptist Colloge. Bapt.. Boliv"at.

2 Missouri Weslevan College. M. E., Cameron.

3 Christian University, Chrictian, Canton. + Christiar College, Christian, Columbia.

5 Stephuns College Bapt. Colmmbia.

o University of Missouri, State, Columbis.

7 Central College. M. E. So. Fayetie.

8 Westminster College, Presb. Fulton. o Protchett Cullog, num-Sect. Frassim so La Grange College, Baft, Ia Grampe. I Tilham Tewell Collegea. Baft. Liberty 12 Missuri Vulley Cullego, Cumb. Presb. Murstatli

r Hatilin C Jllege, Fart, Mexico,

I Park Cilkegr. Presti, Parkrille.

Is Christion Brothers Cullege, R. C., St Lunis.

16 St. Luruis University, R. C., St. Louis.

17 Washngtun Unitersity, non-sect. Si Lonis.

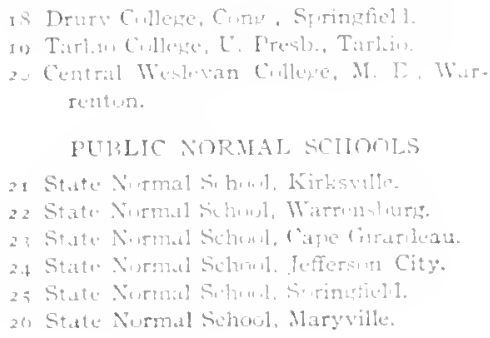

is Drum Culleke, Comp . Sfringtiel 1 .

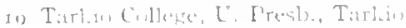
- Central Wentevan Cullege. M. L. Whar Itutitin.

PUTLIC NORMAL SOTHOLS

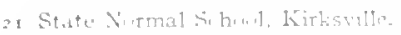

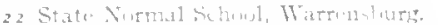

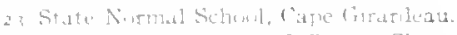

24 Statu Viurmul Sclumil. Tefersin City.

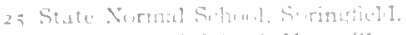

zo State Kurmal Sehowl, Maryville. 
53I, t I p pupils with I 7.030 teitchers. $2 S z$ hirgh schools, 9, 38ormal, and 5 , t city anel town dis. trict schools.

There are also : numler of private schools for ligher

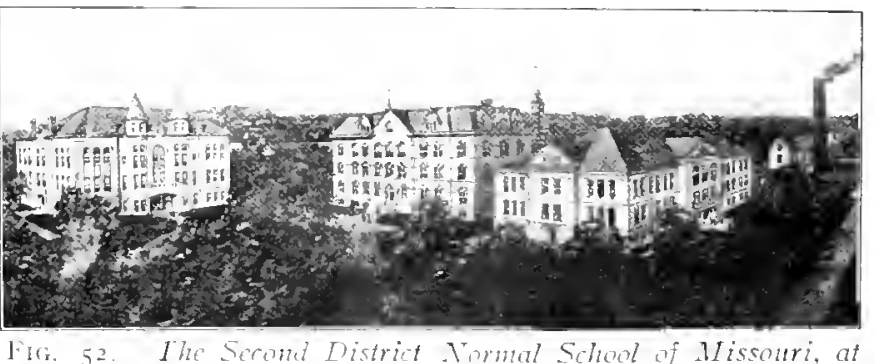
Il arrenshars. children's poct, also mas loorn and reared in this state. (Fige 67 and 68.)

Religion. The first suttlers in Missouri were French Catlonlies from Illinois. The Spanish

commantiunts were of the same faith. Immielucation that are floing excellent work. Among these are Washington Unirersity an l St. Lonis Lniversity at St. Louis, Contral College at Fayette, William Jewell Crilege at Liberty, Mestminster College at Fulton, Christian Brothers College at St. I anis, St. Vineent's College at Cape Girarkeau, Drury College at Springfieli, Missouri Valley Cullege at Marshall, ank1 Park College at Partrille. (Fig. ji.)

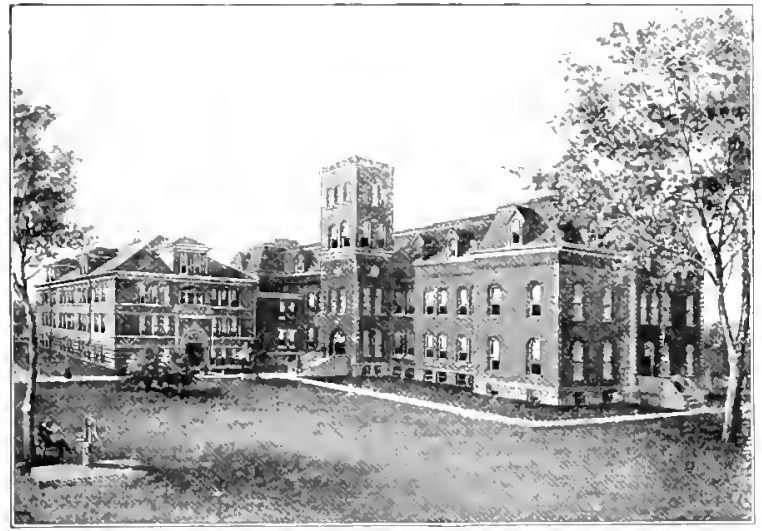

Fic. 53. The First District Nomal Sihod of Missom, at Kirksoille.

Art and Literature. In a new community the material side develops first; lut with inproved conditions come intellectual an! artistic growth. Mnng these lines Missonit has made an excellent beginning, as is attested by the fine libraries and art galleries to be found in St. Louis and Kansas City. Among her artists the most wilely known is Genge C. Binghim. The state pulilications inclute $\mathrm{I}, 000$ newspapers and magazines. The greatest Imerican in'morist, Samuel I. Clemens "Mark Twain") is at native of Missouri, anel Eugenc Fich1, "the Fintucky were chiefly Protestants. The first roligious scrvice of which there is any recorrl was in 1760 , and the furst church enlifice (Catholic) mas built in 1770 in St. Lomis.

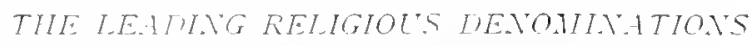

\begin{tabular}{|c|c|c|}
\hline CIURCII & $\begin{array}{l}\text { Prganized or } \\
\text { Fonmited }\end{array}$ & $\begin{array}{c}\text { Communicants or } \\
\text { Mevmbirs }\end{array}$ \\
\hline liatet is & 1794 & 150,000 \\
\hline Cathold & $17(10)$ & 202.000 \\
\hline Chroting. & 1520 & 175,000 \\
\hline Conire:stiona! & 1855 & $1 \mathrm{r}, 000$ \\
\hline Cumberand Proshyterian & 1820 & 30,000 \\
\hline German Erongelical & I 840 & 20.000 \\
\hline German Evan'. Lutlicran & $19+7$ & 30.000 \\
\hline Methodist . . . . & I So6 & 200,000 \\
\hline Presbyterian & I S I I & $2,0,000$ \\
\hline Prutustant Errseopal & 1510 & 12,000 \\
\hline
\end{tabular}

The first Protestant preacher of whom there is any reeord crossed and recrossed the Mississippi in his skiff to preich to the pioncers near Jackson, in Cape Girarkleatu County. This was in 1770 . And in 1806 the first l'rotestint church was Juilt and dedicated.

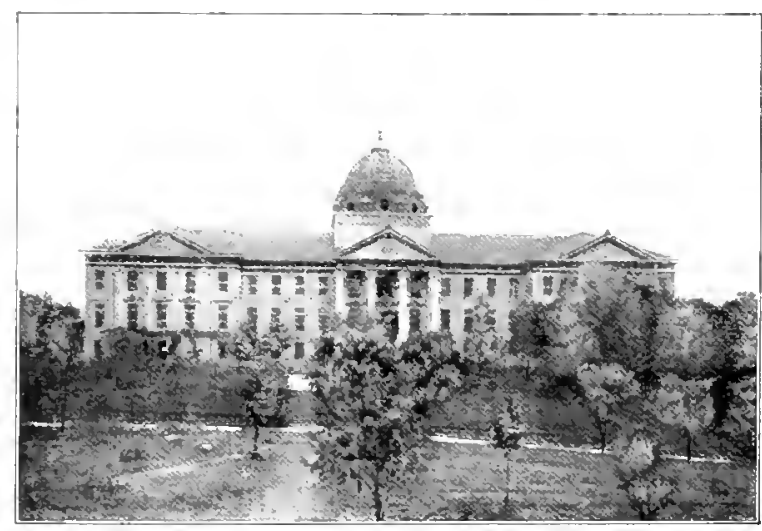

FIg. 5t. The Third Destrict Normal Schoo! of Missour. at Cufi Girurdiau. 
II. THE GROITTH AND IOEIELOI'MENT OF CITIES.

Gain in Population. In recent years there has been a remartialle growth in the urlan population of Missuri at the expense of the rural. Between I Bso and rooo, the gain in total population in Missouri was 15.155 1 er cent, the gain in rural $3.6+$ ler cent, while the gain in urkan population during the decale wats 34.54 percent. In ruco out of a total populittion of $3,106,065,40.23$ per cent, or nearly onehalf of the whole, resided

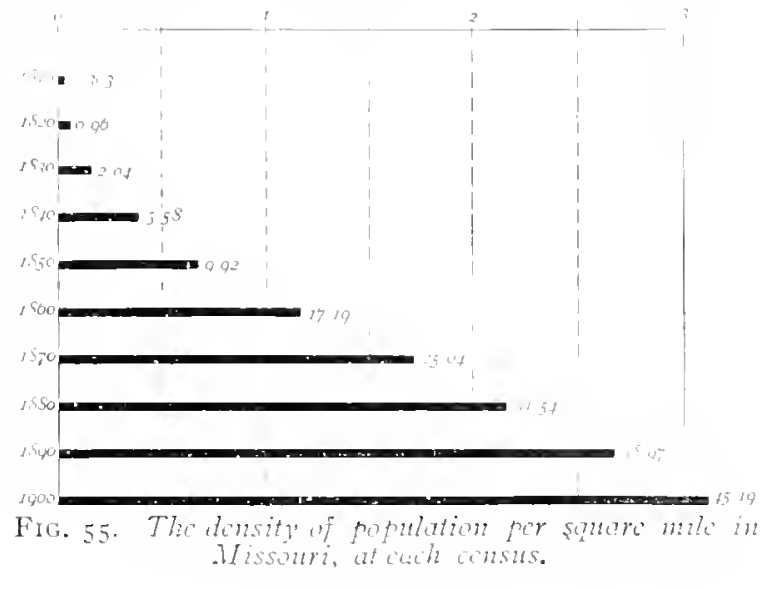

for growing industries. The popnlation figures given in connection with the cities which follww are from the Twelfth lecleral Census.

St. Louis $(575,23,8)$, the oldest and largest city of the state, lies on the Mississipli River almat twenty-one miles beluw the mouth of the Missouri, a situation that offered excellent facilities for the alevelopnuent of trade. The area of the city embraces alunt sixty-two square niles, with a water front of alout iwenty niles. lts situation is beautiful, and the city, hanlsomely anel substantially built, contains many fine 1 ublic and private most efficicnt street railway system. (Figs. 57,58, and 60.)

St. Louis ranks fourth among the grat cities of the Union in population and manufactures, and, among the cities of the Mississiplin Basin, one-third of the total within the state. This great adrance in urban ponulation is due lariguly to the immense growth of agricultural and manufacturing industries and to the derelopment of rast mineral resources within the state, conditions creating demands for new markets as outlets for increased products or as centers of supply

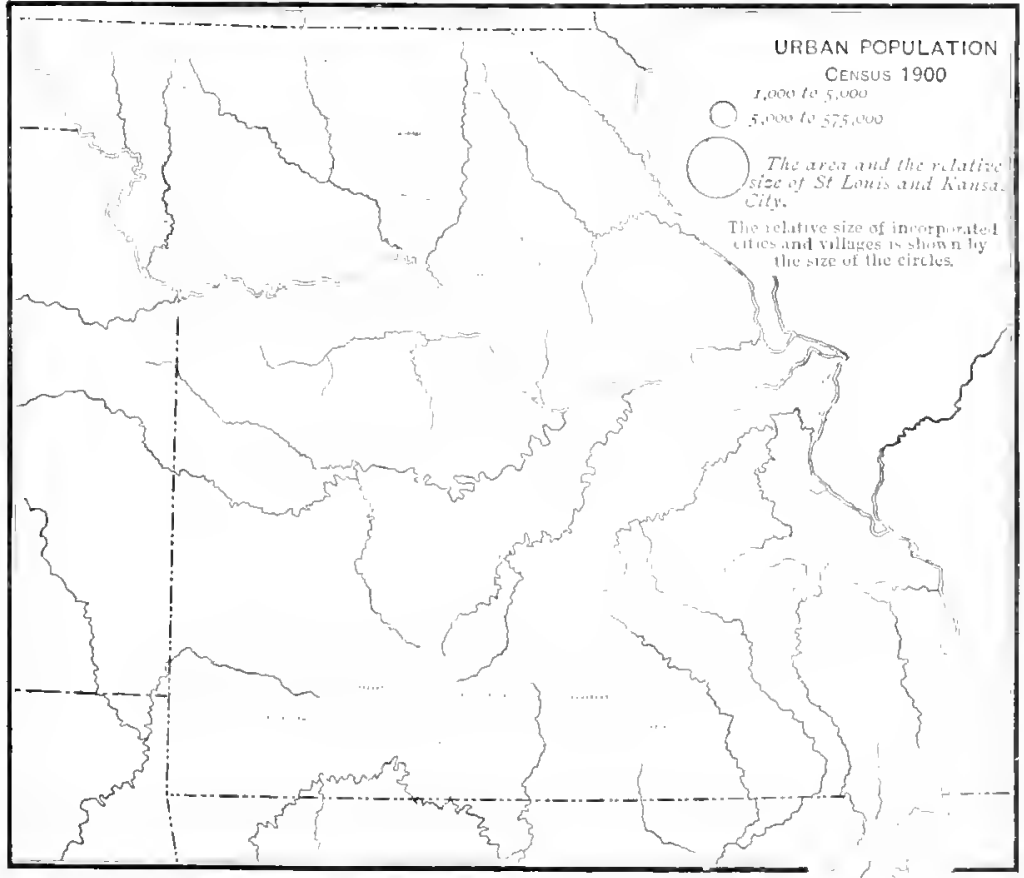

Fig. 59. The distribution of urban populatwn in Missouri. census of 10uo. with the execptium of Chicago, is without a rival as a commercial, manufilcturing, and financialcenter. The city owed its settlement and carly development to the fur trade, which at once made it the center of distrilumtion for the western cruntry. $\quad$ In 1 - 50.3 Dicare lackole and Auguste Clouteau opener a furtrading station 




Fig 57. Mup of the city of St. Luis and lininity. 


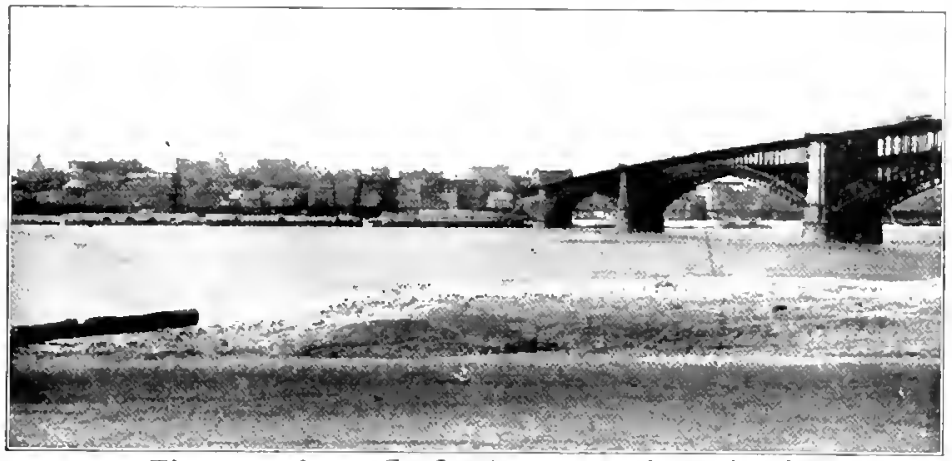

Fig. 5S. The zeater fromt, St. Loutis, as seen from the shore at East 5t. Louts. Wote the great Eads bridge on the right.

educational justitutions in the Union. The Catholic furuchial schonls atre excellent wnd there are many other goml henominational schools. The leading libraries are the Nercantile, the Pullic, aml the Jaw Lilsrary.

The park system is notable alike for its extunt and its beanty. Forest Park, where the Fair was helk, the largest of the public parks, contains $\mathbf{1}, 400$ acres, white the most widely known is the Missouri Botanical Garden, or Shaw's Garden. (Fig. 50.)

on the site where the city now stands. Thrifty and industrious French immigrants speedily gathered around them, traffic extended rapidly and the community soun became a prosperous Frenclis settlement. Following the Joutisiana Purchase in ISoz, came Antericans from Virginia, Tennessee, and the Carolinas. Later came people from England and Cermany, and the population increased from $\mathrm{I}, 000$ in 1803 to 16,000 in 1840.

The builling of the first railway west from St. Louis, the Pacific,

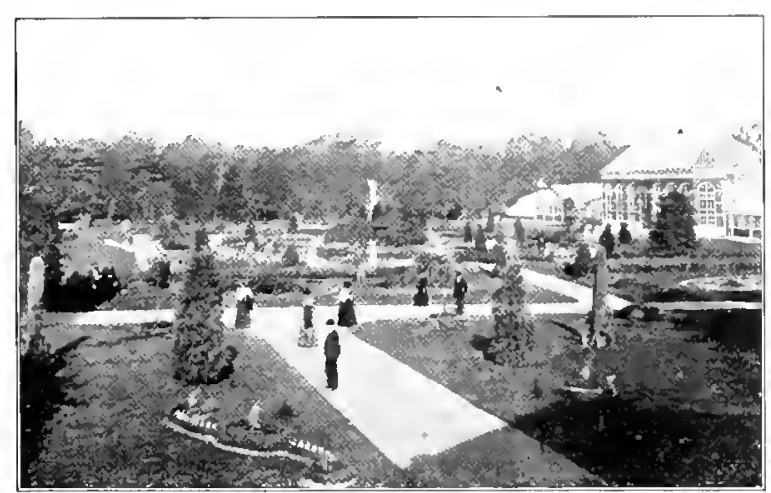

Fir. 50. Ticw an the Missouri botmical Gurden-Shane" Gorden. This garden contatins one of the must artenstic collections of natare and forcign flope in tmerad.
Kansas City $(163,752)$, on the western borler of the state at the confluence of the Missouri and Kansas rivers, the secont city in the state in wis begun in I $_{5}$ T. Now the city is the termimus of twent $y$-frour railroarls, and its transportation facilities are among the most extensive ind efficiont of any city in the country.

Two magnificent bridges-the Eads and the Merchants-span the Mississippi at St. Loutis. These rank among the notalile bridges of the worla, while among the largest railway stations is the Union Station of this city The Jouisiana Purchase Exposition, held in St. Louis in Inot, owerd its magnificent success largely to the efforts of her eitizens.

St. Louis is moted for her excellent system of pultic schonls, and has many superior frivate schools. Washington Cnirersity is one of the leading size and innortance, is termed the sateway to the West. It is the commercial metropolis of a wike region remartable for its fertility and its great mineril wealth. Jn reality Kansas City, Mo., and Kansas City, Kans., are, ju commerciul interests, (me city. and only the accident of a state line renders two city governments necessary. Together in yoo the two cilies had 2 I5, r70 inlnabitints. Lilie St. Jouis, Kinnsas City owed its foundation to the fur tracle. In I $826 \mathrm{MI}$. Clouteau

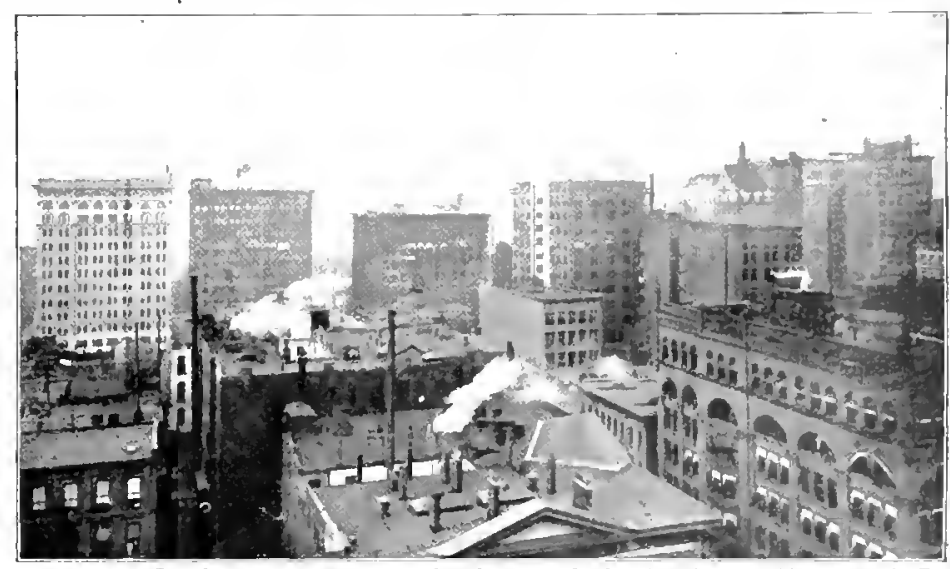

FIG. 60. Looking don' "un the heart of the business district of $S t$. Luthis from the court house. 
estiblished a branch of the Anerican Fur Company at the present site of Kansas City, which until Is 38 was known as Thestport Landing. The growth and develoment of the city have beut stearly ani continuous. Is nuanufactures increased ancl trude extended railroad facilities grew proportionately, and the rity is now one of the greatest railroad centers in the Lnited States.

Kansas City has an excellent location. The nuanufacturing and wholesale district of the city is built largely in the low, lew land lying adjacent to the rivers, while the retiil and resident

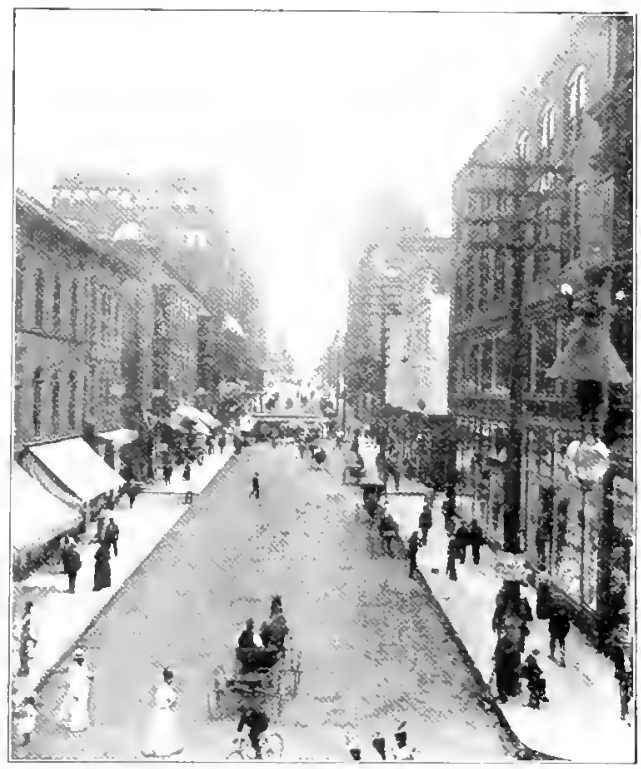

FIG. 6I, Eleath Strect east from Muin Siret Kansas City, the rewil shopping district of the eity.

an important grain market ancl is one of the greatest distributing centers in the world for agricultural inflements. The confectimery, fruit and i roluce, milling, lumber, millinery, ancl numy other interests are large and important.

The city has also lookerl to lighther things, and is widly linmen for beatiful churches and justly urout] of its public schonts, which rank among the best in the country. The four ligh schools have the largest attemiance in propertion to population of any schools in the Union, and its Central and Manual Training are the portions are built unon the bluffs and liils sinulted south and cast of the rivers. It has an extensive park and boulerurd systen which greatly entances the natual beanty of the city.

Its ineat-packing industry, including the fraking louses of Lansas City, Kans, and its live-stock trade, which is the second largest in the workl, are exceeher only hy those of Chicago. These form the leading industries. The ity is

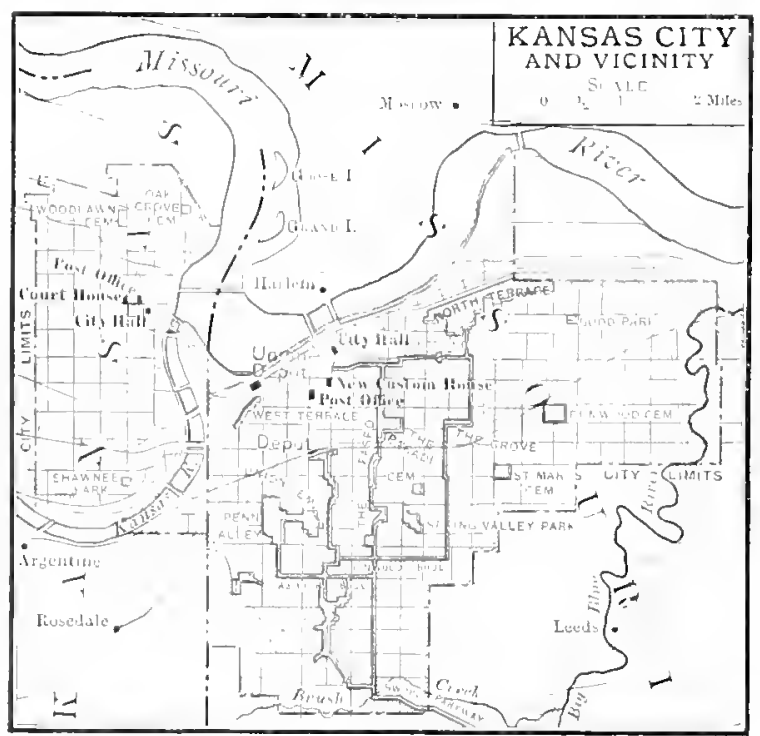

FIG. 62. Hap of Kansas City and sicinity. largest mixed high schouls in the workl. The School Board atso controls the Public Library of 100,000 volumes housed in a classic huilding

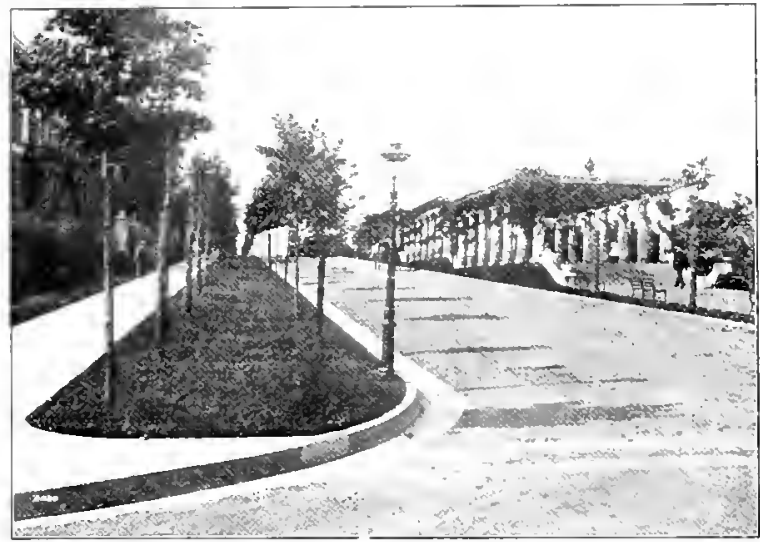

F1g. 6.3 The Perenlis on the P'asco Kansas City The Pasce, with th theth of purks, is one of the mest

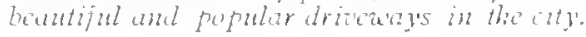

which likewise, contains an excellent Museum and an Art Gallery, with many instructive and well seleeted works. (Figs. 61, 62, and 63.)

St Joseph (ro2,979), the county seat of Buchanan County, beautifully situated on the Missouri River in the northwestern corner of the state, is the third city in Missouri in size, wealti, anul commercial importance. (Figs. + I, 45 and 6.) 
The first settler on the site was Joseph Robidoux, an Indian trader. The town was laid out. in $1 S_{43}$. St. Joseph has great natural advantages. It lies in the center of one of the most fertile regions in the country, and, having sujerior transportation facilities, has become one of the greatest inland marlicts in the Inited States. The most important industry is the livestock trade with the meat-packing interest. The city has many flourishing industrial plants. The principal manulactures are woolens, boots and shoes, hardware and harness, flour, plows, furniture, cusperage, carriages,

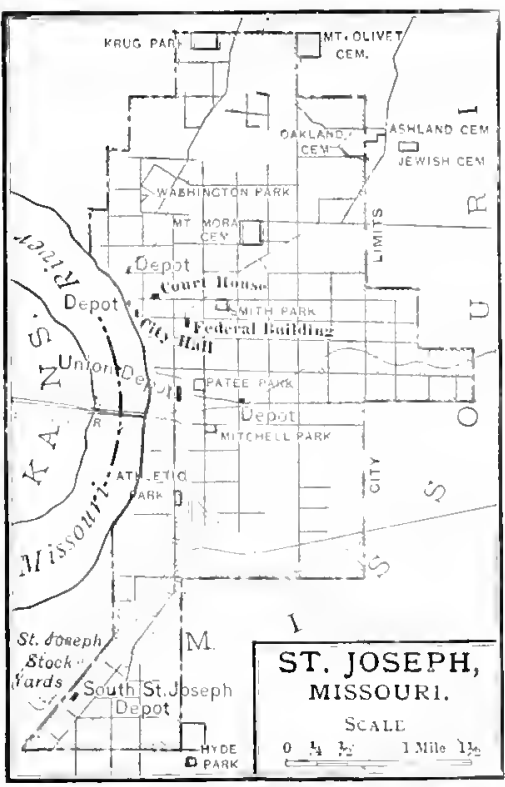
bugrgies and wagons, confection- FIg. 6. Map of the city of St. Joseph. buggies and wagons, confection- FIG. 6. Map of
ery, foundry products, malt lisuors, and clothing. The butter and dairy business is extensive, and the grain and seed interests employ considerable capital.

St. Joseph has a fine system of public schools, as well as excellent private and parochial schools. There are two public libraries and five city parlis.

Joplin (26,023), situated in Jasper Connty in the extreme southwestern part of Missouri, is the commercial center of the great lead and zinc mining districts. Five-sixtls of the zine mined in the United States is taken out of mines in the vicinity of Joplin. The city is building up a large jobbing business and has a number of flourishing industrial plants including foundries, machine shops, and flouring mills. It is a city of many churches and has one of the hest systems of public schools in the state.

Springfield $(23,69.3)$, the county seat of Creen County, situated on the Ozark Platean at an altitude of $1,32+$ feet, is the leading commercial center of southwestern Missouri. It has a wholesale

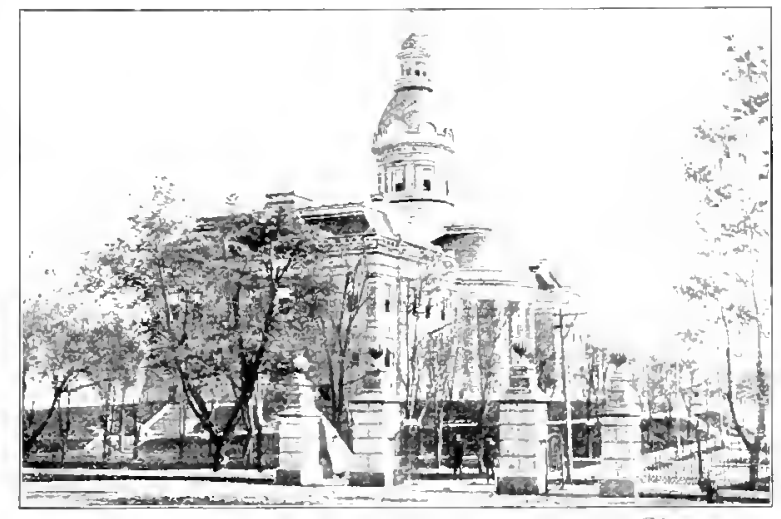

Fig. 65. The likte (iphth at Jefferson City. trarle of \$ $\$ 0,000,000$ fur itn11um and an outfut from its factrines of si $5,500,000$. Siringfiels maintains excellent pullic aml several private schools. Drury College and the Soutlinest State Normal School are located hore Fruit growing is an important in linstry of the Ozark region, and Springfield is the market for larger]uantities of these profucts.

Sedalia $(15,23 \mathrm{I})$, the cotinty seat of Pettis County, is a Alourishing railroad center and a job. bing print of importance. The public schools rank high, as do also several private schorls.

Hannibal (12,750), is perliaps best known as the town where "Mark Twain" passed his boyhood. (Figs. 67 and 68.) The city, beantifully located on the Mississipni River and at the junction of five railroads, yossesses unusual transportation adrantages. The frincipal industries are the manufacture of shoes, stores, lime, and Portland cement. It has the largest cement factory in the world. The public schools are excellent, and there are numerous private schools of a high order. (Fig. 66.)

Jefferson City (0.664), the capritai of Missouri and county seat of Cole County, is on the south bank of the Nissouri near the geographical center of the state. On ligh bluffs orerlooking the river are the capitol (Fig. 65), the Gorernor's mansion, and the State Penitcntiary. The legislature assem1)]es once in two vears in the rapitol to maklie law for the state. The cit:

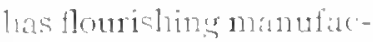
trories ancl is nuter for its schools and lilmuries.

Carthage (0)+ I 6), the (")untr seat of Jasper Countrin thesnuthwesteril part of the state. is the seventh city in size. The surroumding country is rich in lead 


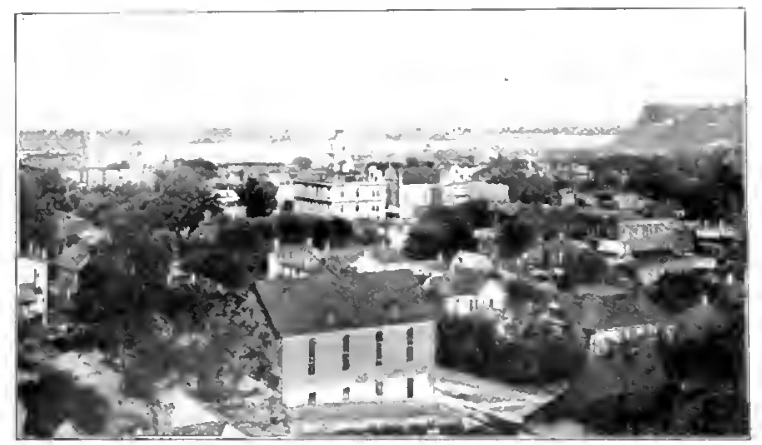

Fig. 66. A rice of the city of Hamibal. Notuce the G. Parmant building in the center, and in the distrane Lnerers' Lian and Purates' Istand.

zinc, and limestone and the city's trade in building stone is large. It has a gond system of public schools and has several private schools, $a$ fine litrary, and beautiful parks.

Webb City $(9,20 \mathrm{I})$ is situated in the midst of rich zinc and lead fields and is surrounter by a fertile agricultural region. The mining, smelting, and shipping of lead, zinc, and coal are the chief industries. It also has foumlries and manufactories of mining machinery.

Moberly $\left(8,0 \mathrm{I}_{2}\right)$ is in Randolph County, the leading county for coal mining. Railroad shops and the manufacture ef paring and building brick give cmployment to a large number of people. It is one of the inmportant railroad

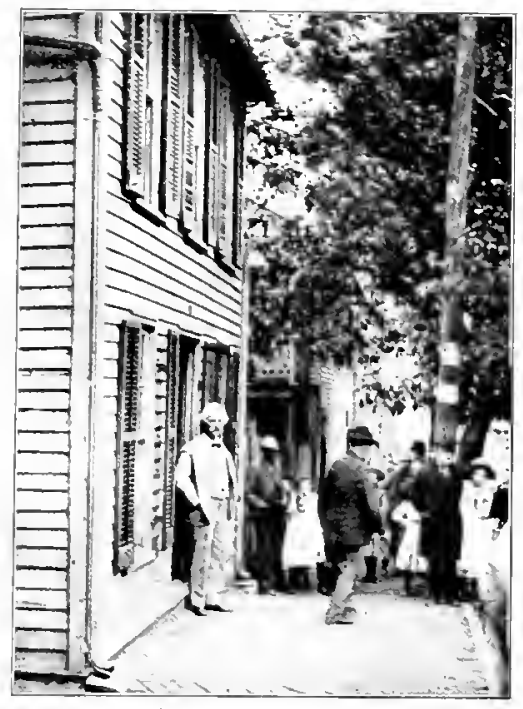

Fir. 6-. Sambel L Clenens C.Mark Tu'din) in the doorien of his old home a Tlanmbal.

system of public schools and excellent private schools. It is the site of a State Hospital for the Insane, and has a large park.

Independence $(6,974)$, the county seat of Jackson County, is situated ten miles east of Kansas City, with which it is connected by steam and electric car lines, and two rock roads. $l_{t}$ is a well built city, the center of a fertile, highly improved district and has a large trade.

Chillicothe $(6,905)$, the county seat of Livingston County, nincty-five miles northeast of Lansas City, is a railroad center of importance. It is surrounded by a rich agricultural country. Here is the State Industrial School for Girls.

Aurora (6,191) is the flourishing tracle center of a lead and zine mining district. The surrounding country is wcll adapted to fruit growing and agriculture. It has excellent schools.

Kirksville $(5,966)$, the county seat of Adair County, is in the midst of an agricultural and stock-raising community. It manufactures flour, wagons, axe handles, and cigars. Coal is mined near by. The town has excellent public schools and is the seat of the First District Normal School, founded in 1870 , and of the American School of Osteopathy.

Columbia $(5.651)$, the county seat of Boone Countr, is near centers of nortlern Missouri and has a large and flourishing trade.

St. Charles $(7,082)$, the county seat of St. Charles County, is situated on the lluffs of the Missouri River, about twenty miles northwest of St. Lomis. The principal industries are the mannfacturing of cars, tobacco, compressed brick, and the quarrying of stone. It has excellent jublic schools as woll as a number of gooil private schools.

Nevada $(7.461)$, the county scat of Ternon County, is the marliet for a fine agricultural region underlaid with coal. Mining industries consisting chiefly of coal and asphaltum are carried on near Nevada. The city has a fine

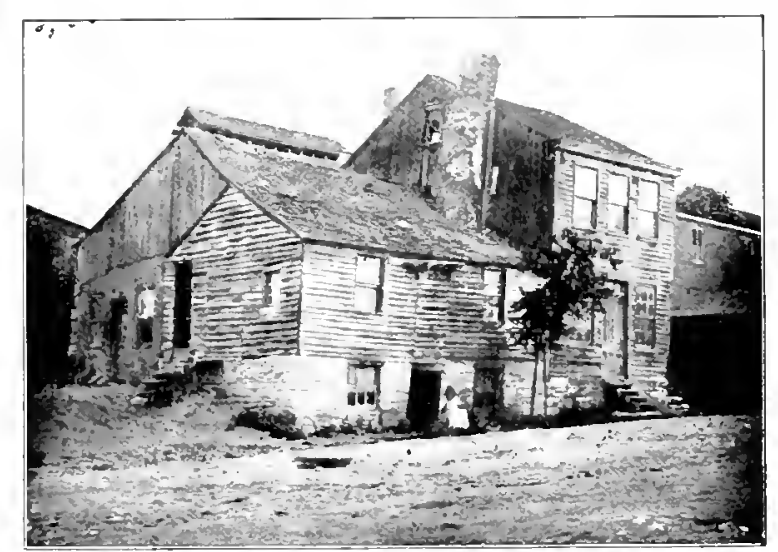

Fig. 68. The home of Hiwkleberry Finn, Hanitibul. 
the center of the state, in the midst of a fine agricultural and stockraising district. The seat of the State University and of a number of other excellent educational institutions, the interests of Columbia are largely educational. (Fig 69.)

De Soto $(5,6$ I I ), Jefferson County, fortythree miles soutliwest of St Louis, is an important railroad town, and has flouring mills, brick works, marble works, and planing mills. It has good pulilic se hools and excellent private schools.

Brookfield $\left(5,4 \varsigma_{4}\right)$, in Linn County, lies in the center of a productive farming country underlaid with coal. It is the seat of railroad shops and has important factories.

Trenton $(5,396)$, the county seat of Grundy County, is situated in a region adapted to general agriculture and is adjacent to coal mines. The chief industrial interests are centered in cattle, coal mining, the railroad shops, flouring mills, and carriage factories.

Louisiana (5,I3I), the leading city of Pike County, is on the Hississippi. It is noted for the great railroad bridge that here spans the river, its large nurseries, cement factory, and its lumber and pearl button industries. (Figs, 70 and 72. )

Mexico (5,099), the county seat of Audrain County, a thriving town in the midst of a distriet devoted to the breeding of fine stock, is a notable stock market. It is the seat of Hardin College for girls and of Mexico Military Acar]emy for looss.

Marshall $(5,086)$, the county scat of Silline County, is the trate center of a fertile, well improved agricultural district. Near by are celebrated mineral springs. Missouri Valley College and the Missonri Valley Culony for Feeble-llinded are located at Marshall.

Clinton (5,06r), the county seat of Ilenry County, is a thriving industrial and trade center eighty-seven miles southeast of Kansas City. The aljacent country is well arlapted to agriculture and stock raising. The chief industries are the manufacture of flour and tile. The Baird College for women is locitted here.

Fulton $(4,883)$, the county seat of Callaway County, is the trade center of a fine agricultural and live-stock region. lts stock sales attract wide attention. Coal and fire clay are mined in the vicinity Here are a number of excellent erlucational institutions, the Missouri School for the Deaf, and a State Insane Asylum.

Cape Girardeau $(4,815)$, on the Mississippi 150 miles below St. Louis, is a leading railroad and distributing point. The chief interests are manufacturing and the tracle in agricultural products. A State Normal School ancl St. Vincent's Convent and College are located here.

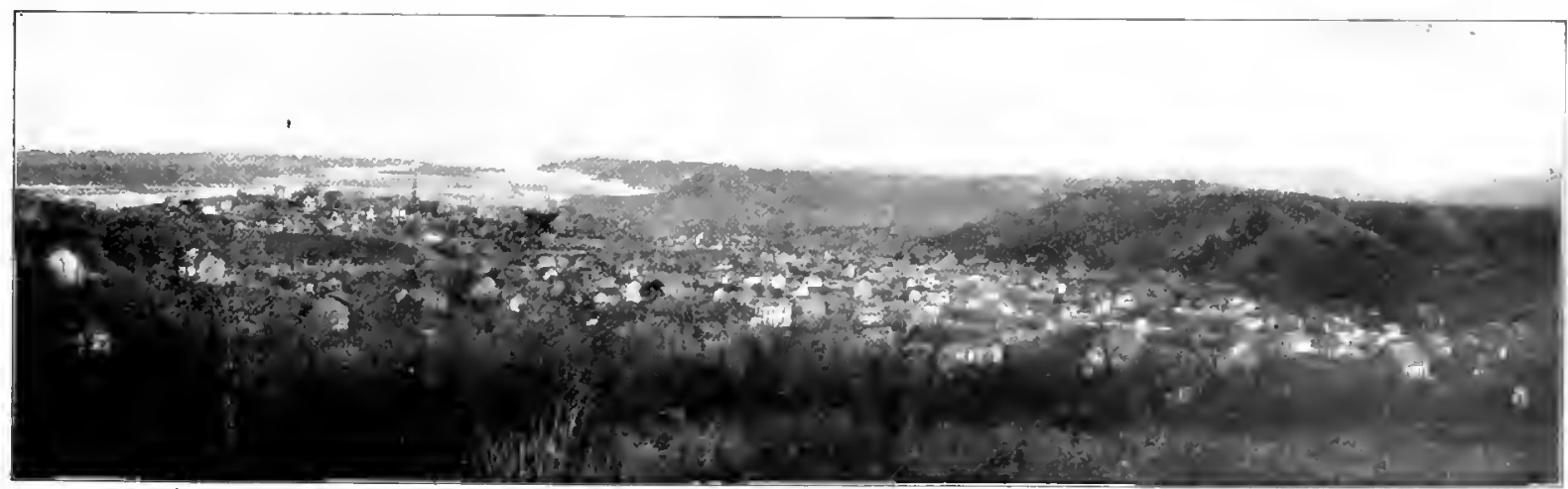

Fig. 70. The city of Lomisiana. Note in the distance the bluffs of the Wississifpi and the rolling horderlands

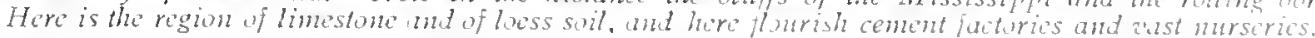


Warrensburg $(4,724)$, the county seat of Johnson County, lies in at fine agricultural and live-stock district. It has manufactories of flour. store polish, and shoes. It also has large stone quarries and coal is mined in the ricinity llere is one of the most flourishing of the State Normal Schools. Near by is Pertle Springs, a famous summer resort.

Maryville $(4,577)$, the county seat of Nodaway County, is situater at the junction of two railroads. It is the trade center for a thriving agricultural and live-stock section, and has foundries for iron and steel bridges. llere is the seat of a State Normal School.

Carterville $(4,4+5)$ is the fourth in size of the large industrial towns in Jasyer County, which is the greatest zinc-mining district in the world.

Boonville $(4.377)$, the county seat of Cooper County, is situated on the Missouri River in a district devoted to farming and mining. Corn, wheat, and onts are shipped. The lealing manufactures are leather, earthenware, and flour. Coal is mined in the ricinity A State Training School for Boys is located here.

Poplar Bluff $(4,321)$, the county seat of Butler County, is situated on a bluff overlooking the lilack River. It lies adjacent to a large tract of lowland, covered with a variety of hardwood timbers. Lumber, staves. woodenware. and flour it re manufactured. It has iron and machine worlis and a large shipping trade in lumber.

Le $\mathrm{x}$ ing $\mathrm{ton}$ $(7,100)$, on the Missunri River, the countr seat

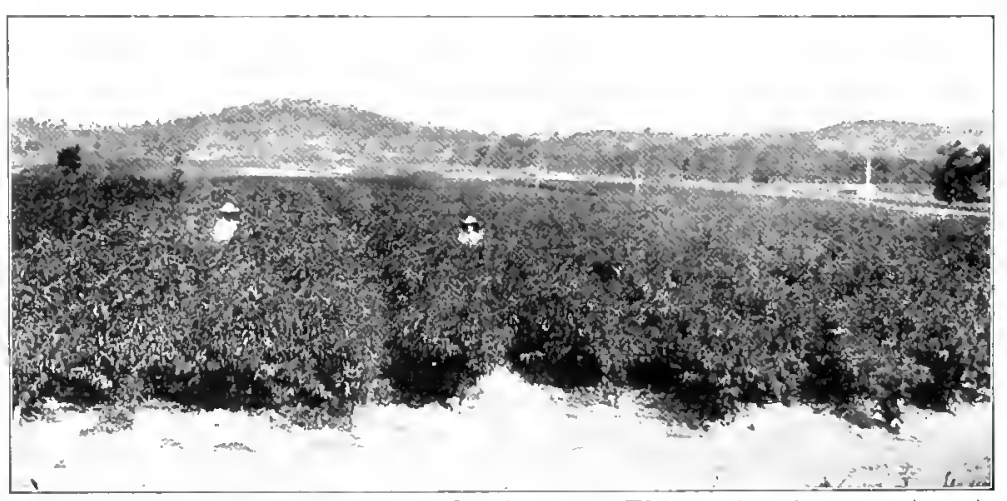

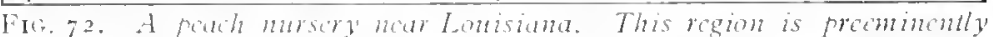
adapted to frith growng, and here are some of the abrlt's latgest nursiries. of Lafayette County, is the center of an agriculturil and coal-mining section. The chief industrial establishments are furniture, flour, and canning factories.

Macon $(4,068)$ is the county seat of Macon County. It has a large trade in agricultural products and important mining interests. Wagons, carriages, and slears are manufactured, and it also has a foundry and machine shops. Naton is the seat of Blees Military Aeademy.

Rich Hill $\left(4,5^{\circ}\right)$ is situated in the midst of a rich farming and mining district. live-stock raising, the manufacture of flour, and eoal mining are the elief industries.

Towns with a Population of Less than 4,000. In the IIt counties in the state are mans other thriving towns. Liberty, Clay County, is the seat of Irilliam Jewell College. This county likewise cont ins Excelsior Springs, a popular summer pleasure and health resort. Potosi, the county seat of Washington County, is one of the oldest lead-mining eenters in the state. It is noted also for the mining of baryta. Fayette, in Howard County, is the location of Central College, established fifty years ago, and Glasgow, in the same county, is distinguished for the observatory work in connection with the Pritehett lnstitute. Carrollton is a flourishing trade center in Carroll County. and Eldorado Springs is a widely known lhealth resort in Cedar County. West Plains is a growing market town in Howell County, one of the leading fruit distriets of south Missouri. 


\section{HIDS IOR TEACIIERS}

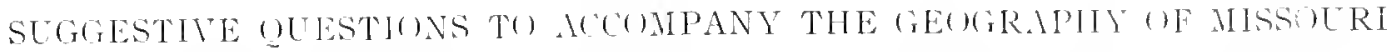

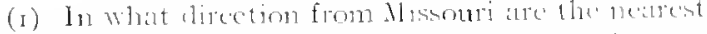

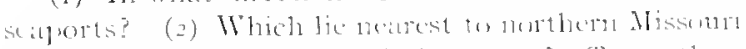

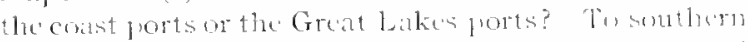
Nissourt? (3) To what state if the Union is Missenti

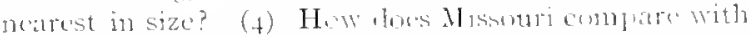
Jexas, the largest state? (5) How many states ate

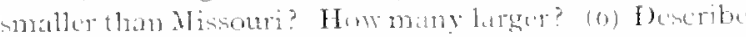
the chatracteristic senery of the setetem of the state

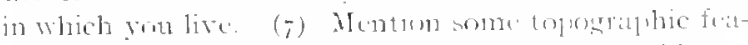
tures thit cast in your recinity (s) Ilow mathl you

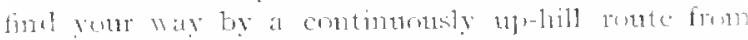
the Jississiflit River to the highest prat of the state? (a) What is the lighest altitule in the stitle and where is it fomme? (10) Fimel the source of some large river that flows through or neat your conaty Now what watershed foes its somed lie? (11) If you were asked to plan at raiboul crossing your state from

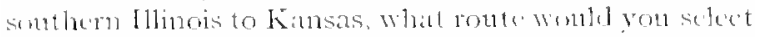
to secure the celsiest grate? Explain your selection (12) ran you give any physiggraplic natson why ratirouls should be fewer in the sontlene thate in the morthern part of the state? ( 1,3$)$ What states fonttribute water to swell the volume of the navigathe

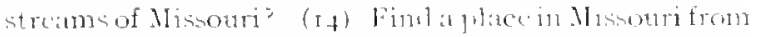
whence at rowbot might reach the Misissiple Ruer ly gassing through three other states and territories (15) Find in Fig s a groul wernnties in which yom woull expect rocky bluffe to bu antirely lacking. Tell why (10) If you were tre sink a lexpe well wate

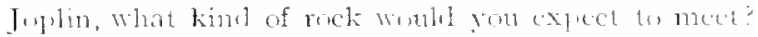
(17) What kind near st fosepin (as) If all manth. rock were striphed from the state, where wothl you exprect to fint the sreatest devations remationge Why? (10) In whit portion of the state wothl you fond the mere rugged secnery? Why? (20) What is the tralitional explanation of the lowlands in the sonthastern part of the statu? (21) After Jobking at Fin 14. fiom what thection woult you exject the rainbalen winds to come? (22) fu what prot of the state workd you think the greatest number if sumshing day would be recorlent? (23) Is it possible tes tell from Fig. It where snowstorns are mont frupuent? $(2+)$ Can you see in Fig. + a possible a cilandation of the southwarl bend of the $50^{\circ}$ inotherm in fig it? Of the similat bent in the $52^{\circ}$ inotherm? (25) Where wathl yru expect, after tooking at Fig 1 , to fimel the mont luxuriant plant growth of whil varietis? Why? (20) From what is said of anminl life in the southem part of the state, what would you infer is to the density of purvtation there? (2y) Jn what waty dous the sitte Fish Commisson abl the extersion of fish-

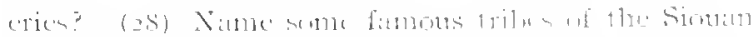

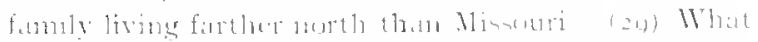

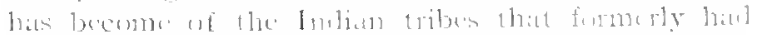

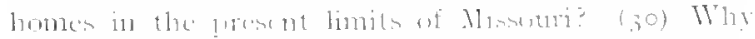

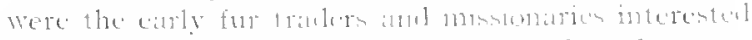
in the lacation of lublun trilus? (31) For what gur-

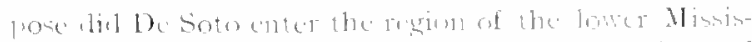

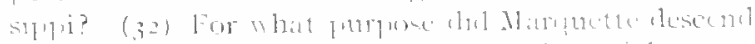

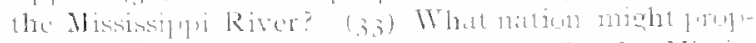

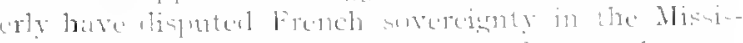
sipig Valley? (3i) Mhy were the tiret settlentents

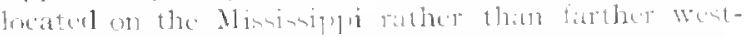

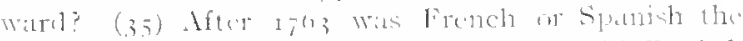

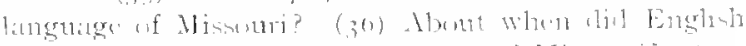

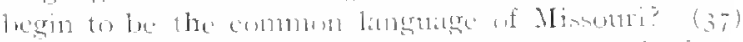

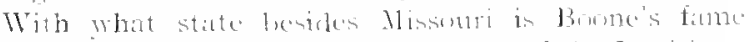

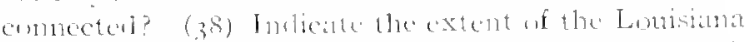

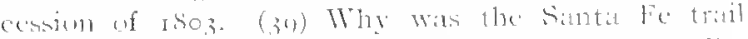

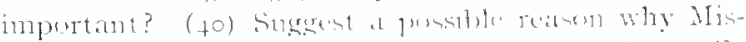
werians were interested in the calture of Sinta le uspecially. (+1) What is meant by "stivery"? By "a slave state" (12) Fiml in Fin + al posstile

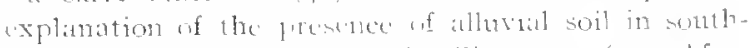

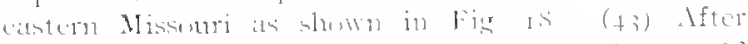

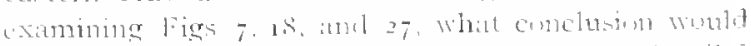

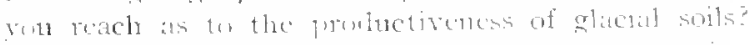
(4) What crincilenec as to climate and com-growing

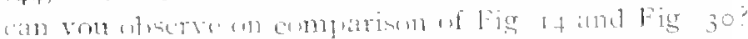

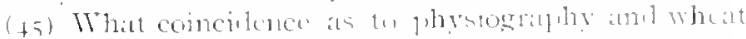

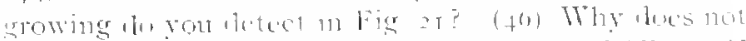

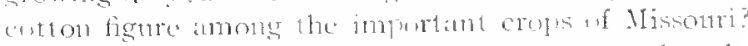

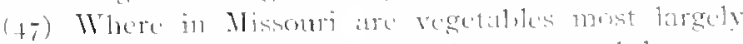

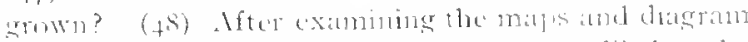

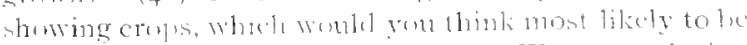

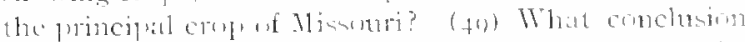

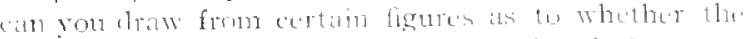
fibltiat comntry of Missurt is goml for frut groming? (50) What ate the principal fruts matheter from your pert of the state? (51) Why ate hest raised in

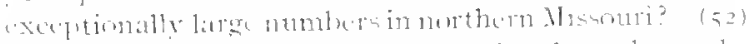

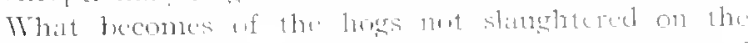
farms where they atre ratist? (5) The what flate of

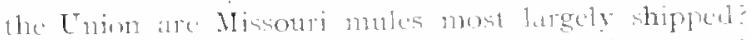

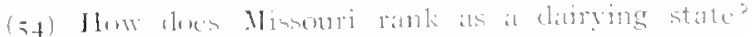

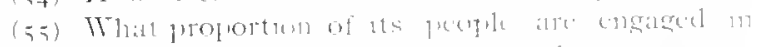

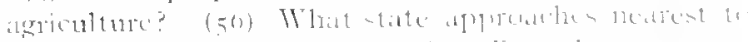

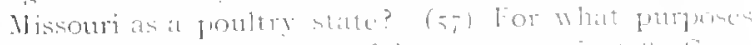

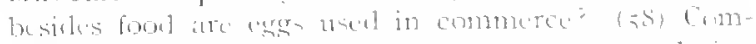

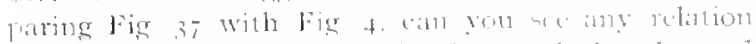
between the metallifurnes distrets and the chevated region? Can you strgesest any themy hace ount for it? 
(50) Nime thre towns whowe prosperity depends shifly on minine industry (00) for what commereial

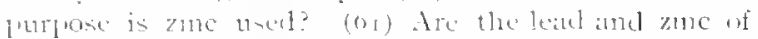
Missourt chichy used within the state? ( 02$)$ What is meint ly a "smeltery" for iron? (103) What can rou tell of the promluction of rold and silver in Missmari?

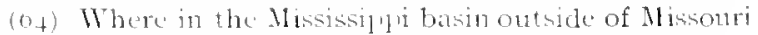
is copprer mined? (65) Ls.Missouri coul of the anthra-

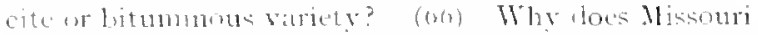
coal find its chice markets west of the state rather than to the cistwatrl? (oj) Why ate tomens near coal mines

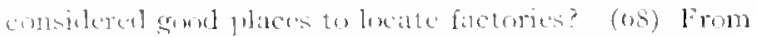
what regions would the trolacen manufacturing industries of $\mathrm{St}$ londin be most like ly to draw their supplies? (oo) Find on page 12 some reason why springficlu slunhl have slour-nilling industries (70) Can you

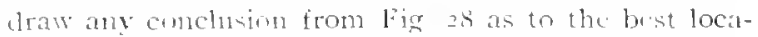
tum in Missouri for fork-latcking plante? (71) Name one or more city intustries that would be liticly to exist in the conter of a fruit-growing regiond of at cattle-raising regine of a wheat-graming region. (7) Where would be the bent place to locate a waronmathing establishouent? (7.) What alvantages do steamboat men have over ribroal mon in eompeting for freight tratfic: ( $/+1)$ What advantages lo raillobid men bare over steamboat men in such completition? (5) What method of transportation is most important to the state as a whole? Why? (-6) Why are railroals mecessary enpecially in a regiom having minual resources? (7) Explain why banks are "necesary factors" in industrial life. (-8) What is the difference between a state ant it national bank? (74) Why should the govenor or any other official fossess the power to pardon? (so) To whom would a city appeal for aid if its own police were unable to keep) pace? What might then be done to enforce quict and wreler: (St) Why is the State Botral of Equalization important? (S2) If you shouthl have $\$$ r.000 taxahle property. abut how much wold you have to gity the stalle cateh rear in taxes? (83) Where does the money come from that pays for the maintenance of your

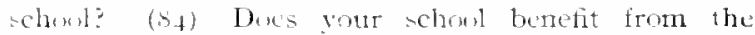
permanent schoul fuml? (sis) What is meant by a "county seat"? (86) Nimm some right or privilege that is conferrel ulum you by the state constitution. (87) Cin the Crenceal Assembly pass is law that will take that right away from you? (SS) If for any rcason you should want some new liaw passed. on whom would fou depend for its presentation in the General Assembly? Why? (Si) What need is there of state conts when the feneral Asembly makes the laws and civil officials are provided to enforee them? (oo) Why should Missouri have sixteen Congressmen rather than ten or twenty? (01) Where du Congresmen go in orter to do law-making work? Why lin they not do their work at Jefferson City, as an mombers of the Goneral Assembly? (02) Why is it necessiry to maintain perdal institutions? $(0,3)$ Why should the state mantain a home for the fechle-minderl? (a) How loxes it hapren that Mlissouri hats a home for Federal Soldiers and one for Confederate Sidiliers also? (05) How does Missouri compre with nther states in its pereentage of illiteracy? (o6) Why loes the state maintain normal schmols? (o) Tell smething that "Mark Twain" has written abuut Missouri scenes a about fersons supposed to live in Missouri (os) Repeat a stanza from some one of Eugene Field's puems $(0,0) \mathrm{Name}$ one of the wirlely known newspapers of Mlisouri (100) Explain why the situation of st Luis "offerenl excellent facilities for the devclopment of trate." (101) Why is the Eals Brilge famous all over the world? (102) Explain why the presence of the state line prevents the consolvilation of the two Kansas City municipalities. (103) $\mathrm{H}$ (n) is the prosperity of a town helped by the centering of railroad lines there? (10.4) That is meant by the statement that certain towns have a "jobbing" tratle or business? (105) What is meant by saying that a city is a "market for a large agricultural reginn"?

\section{SLGGESTIONS FUR COLLATERAL READING}

Barnard, Goemment of Missumi.

Carr, Missurt, a bone of Contentim.

Chitemlen, Hastory of Eurly Stamboat Novigation on the Hessutri Rizer, Ínl.

Cones, History of the Expeditin under the Commond of

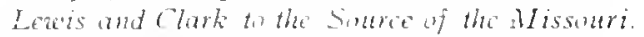

Davis and Dumac. Mllastrated Histury of Messumi.

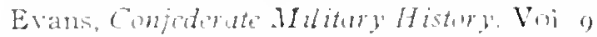

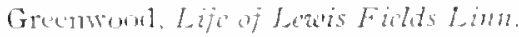

Hogan, On the Missions in Missunt, 1857-68.

Hollister and Normatu, Fine Famous .Messutrians.

Iesse and . Hlen, Missenti Literature.

King, Sturies of a Collentry Dortir.

L.ftwicl, . Hartydim in Missour.

MacNimara, Histery of Missomi (lion Primary Grade.)

Blssouri renlugical Surver. Ammal Repurts.
Missunri Historical Society (St. Leuis), Publications

Monre, Carl 11 ar in Missouri.

Musick, Stories of Missourt.

Owen, Cure Regions of the Ozarks and the Black Halls

Owen, liadere Tales (Negrofolklore)

Parker, Masourt as it is in 867.

Rader. Sihool History of Missourt.

Rice, Rurul Rhymes

Renoserelt. Lifo of Thomas H. Benton.

Snearl. The Fight for Missouri.

Snidy, .Messouli lerses.

State Historical Society of $\mathrm{Nl}$ issouri (Columbia, Mo). Pablatations

Switzler. Illustrated History of Missourt.

Webl. Batles and Biographies of Missumet.

Willams, The State of Missouri. 


\section{REFERENCE TARLES}

Statistics of the State of Missouri, by Counties. Census of rgoo.

\begin{tabular}{|c|c|}
\hline COUNTY & $\begin{array}{l}\text { ORGANI- } \\
\text { ZATION }\end{array}$ \\
\hline Arair............. & 1541 \\
\hline 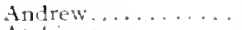 & 154 \\
\hline Atclison,.......... & $1+45$ \\
\hline Aubrain, . . . . . . . . & 1530 \\
\hline Barry,............ & I 135 \\
\hline 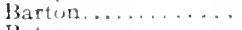 & 1355 \\
\hline 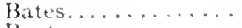 & $18+1$ \\
\hline Benton ............ & $1 \times 35$ \\
\hline Bollinger .......... & $5 \times 51$ \\
\hline Boone . . . . . . . . & $1 \times 20$ \\
\hline Buchanan........ & 1030 \\
\hline 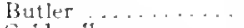 & $1 \times 40$ \\
\hline Caldwell ............ & $1>30$ \\
\hline Callaway............ & $18: 0$ \\
\hline Camulen .. . . . . & $18+1$ \\
\hline Cape Girarteau. .... & I I $_{2}$ \\
\hline Carroti............ & 1833 \\
\hline Carter............. & 1254 \\
\hline Cass ............... & $1 \times 35$ \\
\hline Cellar ............ & $I \$ 45$ \\
\hline Chariton........... & $1 \leqslant 20$ \\
\hline Christan .......... & I 800 \\
\hline Clark. ........... & 1318 \\
\hline 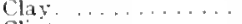 & ISH22 \\
\hline Clinton............ & I 53.3 \\
\hline 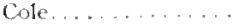 & $1 \times 20$ \\
\hline Cooper.......... & $1 \$ 18$ \\
\hline Crawford . . . . . . . & $1 \times 20$ \\
\hline 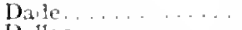 & $18+3$ \\
\hline 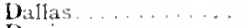 & $1>4+$ \\
\hline Daviess .... ..... & IŚ30 \\
\hline Dekalb.......... & 1845 \\
\hline 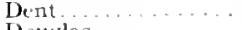 & 1851 \\
\hline 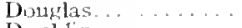 & 1857 \\
\hline 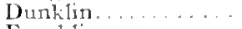 & $1 \times+5$ \\
\hline Franklin $\ldots . . .$. & $1,13.3$ \\
\hline Grisconalte ......... & 1320 \\
\hline Gentry ............. & 1841 \\
\hline Gretne $\ldots \ldots \ldots$ & I 333 \\
\hline Groundy ......... & $18+3$ \\
\hline Harrisun $\ldots \ldots \ldots$ & $18+5$ \\
\hline 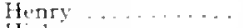 & 1834 \\
\hline Hickiory ......... & $18+5$ \\
\hline Holt $\quad \ldots \ldots \ldots \ldots$ & $1,4+1$ \\
\hline Howari1 . . . . . . & 1516 \\
\hline Howell,$\ldots \ldots \ldots$ & 1857 \\
\hline 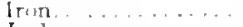 & 1557 \\
\hline Jiteteson $\ldots \ldots \ldots$. & 1520 \\
\hline Jasplet. . . . . . . . & $19+1$ \\
\hline Jefferen $\ldots . . .$. & 1818 \\
\hline Johnson $\quad \ldots .$. & I $8 \leqslant 4$ \\
\hline Knox,$\ldots \ldots \ldots$ & $38+5$ \\
\hline 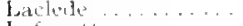 & $28+10$ \\
\hline Latiagette....... & 1820 \\
\hline Lawrence .......... & $1 x+5$ \\
\hline Le'w1s. . . . . . . . & I $\$ 3.3$ \\
\hline Lincoln $\ldots \ldots \ldots$ & Inin \\
\hline Linn $\quad \ldots \ldots \ldots$. & 1537 \\
\hline Lavingstinn.......... & 1837 \\
\hline Medinalu $\ldots . . .$. & $18+13$ \\
\hline Hatein $\ldots \ldots \ldots$ & Is 17 \\
\hline$M_{\text {inllisun }} \quad \ldots \ldots$ & Isis \\
\hline 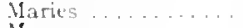 & 1955 \\
\hline Maris $\ldots \ldots$ & $1>\geq 6$ \\
\hline 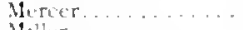 & $14+5$ \\
\hline Mrller $\ldots \ldots \ldots$ & 1537 \\
\hline Mistiscinni & $1 \times 45$ \\
\hline Montcoidu & $1 \times 45$ \\
\hline Minfore.. & 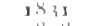 \\
\hline Mntenmery & ISIS \\
\hline Morgath . . . & 1433 \\
\hline New Mialrit $\ldots .$. & $1 \times 12$ \\
\hline Newtun $\ldots . . . .$. & 1333 \\
\hline Notiway $\ldots . . . .$. & 1845 \\
\hline 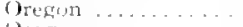 & 1345 \\
\hline 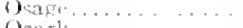 & $x+4$ \\
\hline Ozark $\ldots \ldots$. . . & 1341 \\
\hline 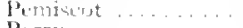 & $1 \backslash 11$ \\
\hline & $19=0$ \\
\hline
\end{tabular}

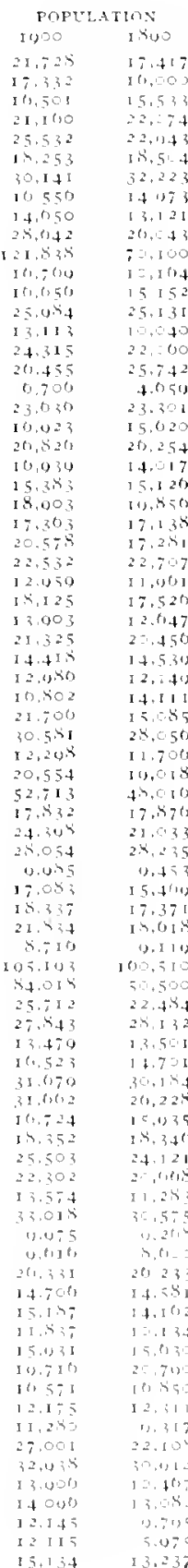

FAR PI PKOERTY
INC LIVE STOEK

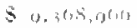

$15,24.517$

$211,53,1019$

$5,1,9,5,74$

$10,014,220$

$26,714,350$

$0,2+1,0=1$

$3,0(1), 7(3)$

$12,46,015$

$15,307,-100$

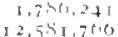

$11,554,235$

$\because 1,00,132$

$19,171+431$

7.103 .025
055.500

$20,270,322$

$5 . x 02,541$
10.245 .537

$4,7+2,-867$

$10,579,217$

$12,4,2,043$

$12.4,520$
$5,3+453$

I 3.501 .315

3. 35,201

(1,ist 451

14. 450,1$) 35$

$3,342+142$

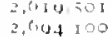

$3,1004.514$

$12,815,45 ?$

$12,015,7,0$

$1:, 1971,312$

I0 181,230

(1).412.733

1.3. 511,508

$3,224,7313$
10.33032

0,$13 ; 2 ; x$

$5,002=313.9$

$1,3+=3=0$

1 $2,10+3,24$

$4.012,1 \times 1$

15.3: 2 1, 44

10, 492,220

$110,100,153$

10, 2006,051

(1) 1900.05 .4

1) $1+10,021$

$14,0633.253$

$19.4511,17$

2.020,1115

$1,134+51,4$

$2,4(1), 471)$

1), 240,13

in, 105 : 130

3.1 + ind 52

6.7.7.75?

$7.071,31: 3$
300,215

$7,1,(13,1) 4^{k}$

$5,284.420$

$3.51+120$

7 311 427

2. $901 \div 51$

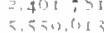

1. 500,1009

$1,42 \div 550$

[ix]
FARM

PROULCIS

r. 2, 2, $1,1, \geq 0$

$2,17(1,4)=5$
$3,047,20$

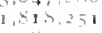

I. 247 . I I

13) 355

$1,+51150$

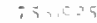

5.cis tis

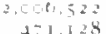

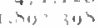

2.1 I : C 30

(1) 4 is ?

$1+10=27$

Iख⿰亻丨

2447,520

I. O1 13,

(1) $4+4$

$4=5111$

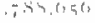

20045.750

(⿻) 2,301

$2.5540104)$
000011

I. 2 प परा 2

IIT, $1: 5$

-12019:

की 10.29

sis $f^{2}$

I. 5095.50

$2+5.117$
$1+1030$

1, $0,7,0 ; 4$

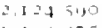

1. 41$) 4.275$
$3,311-412$

3.000 .257

$545,8 \div 5$

1 is 55.501

yot 0 , 3

303.724

$3.53=744$

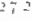

$1.45(1)$

220400

$4+0,034$

2 and 7 on

I (1)

$12+42-114$

I 1) i 5 is

I 1, i1 5 in

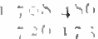

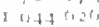

4is] 11 -

4
$1+2$

1, 112:-1010

:25 he

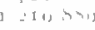

z = 51004

(1) $2:$

1, 321) 42

$4+47-11$

1) $411,2,10$

$+21 \cdot 3+1$

$1,0,4,407$
MANEFAETURES

$+52,240$

$21,415+1$
153.190

7rat in $2=$

- 00,19

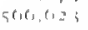

133,2 I 5

5-19.20

$4)^{3}+10,101$

$1,020,307$

45,513
303532

II: 47

$14+121$

$47+172$

$1.275,2710$
245.500

215,440

I 1005

262.42

too, hito

$2+1.14$
5 I $4.1+3$

3. $51+1+3$

127.404

135.111 .4

$3 x 0.0011$

$12+245$

128,37
125.756

I 25,7513
412,358

1,050101

$2 x+5=0$

353734

$52+112$

324,000

(1) $3,55 \%$

Se 570

318.421
$4+40,19$

42025

41) 2111

$=+1013$

Sypenes

$5019,2,1$

I
ग 151557

(x) $3+30$

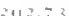

io( i t in)

$50(1,+4)$
$-50,542$

(2) 2 ene

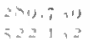

4 (i) $(1,-3)$

$15=28$

I $+1+2$

$\begin{array}{ll}1+1 & 425 \\ 1+4 & 01\end{array}$

4.2 $4=1$

is 5

$24 \therefore(1,1)$

1
$=11$

is 59110

중 11

atomes

$1+3,\{1=$

$21 \div, 1=3$
$251002=$
COENTI SEAT IOPP AT

kitrsiolle

Rek kinat

Cissulle

Lamiat

Butiter

iaterats

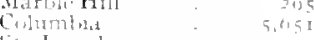

foreth 122,150

Kingsom +4221

Ling Creeti

lacksin

Ltrolltan

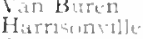

Staktun

Keytusill

Kahrika

Lilerty

Platt<ilure

Jetfersin cit

Bounvill
Sterelullit

Grentivel

Buttalu

Masillo

salem

Ava

Kexnett

Hermaลก

Alkany"

sprantivil

Truturin

Bethany

Hermetay

Prexpen

Favete

Irintura

Initegrabente

Cartlube

Wertembluth

Eisulat

Letant in

Vistut Virnot]

Mientactin

Itos

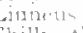

chillow wh

Matcoti

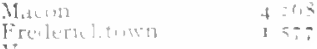

Jitethinat

I'ringeting

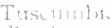

Clinetictiol

I.this

). $+1,11$

Yinatille

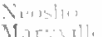

Altin]

Linn

Cindestile

Caritherwille

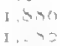

5. $11 \%$

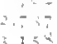

$+3$

321
0,53

is

1
3

1244

I 11:?

1,415

$=40$;

d) thet

ti,ín

I $4=1$

$1,7=2$

1. 425

$15: 0$

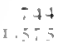

2.023
$3,50=$

$5,3,0$

$\therefore, 0,3$

$10: 2$

3.17

$-107$

3) 4

11419
254

$+24$

1,105
2.125

$+100$ 


\begin{tabular}{|c|c|c|c|c|c|c|c|}
\hline \multirow{2}{*}{\multicolumn{2}{|c|}{ coust: }} & \multirow{2}{*}{ 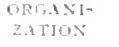 } & \multirow{2}{*}{$A R E-1$} & \multicolumn{4}{|c|}{ PUPELATIOS } \\
\hline & & & & \multirow{2}{*}{ ग1300 } & \multicolumn{2}{|c|}{$i 31,0$} & ic. \\
\hline \multicolumn{2}{|c|}{ Pettis........... } & $1 i_{i}$ & 115 & & \multirow{2}{*}{\multicolumn{2}{|c|}{$\begin{array}{l}311 ; 1 \\
12,130\end{array}$}} & \\
\hline \multirow{2}{*}{\multicolumn{2}{|c|}{ 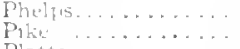 }} & 1957 & $1: ?$ & $1+1.14$ & & & \\
\hline & & 1 is & $1+20$ & $=5 ;+1$ & \multicolumn{2}{|c|}{$2[1+i 21$} & \\
\hline \multirow{2}{*}{\multicolumn{2}{|c|}{ 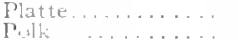 }} & $14: 4$ & 413 & $1+[1):$ & $114,=$ & $=4 i$ & \\
\hline \multirow{2}{*}{\multicolumn{2}{|c|}{ 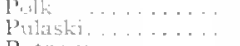 }} & 1.2:5 & いラ: & 22,255 & \multicolumn{2}{|c|}{$20, ; 211$} & \\
\hline & & Isis & $5 i 2$ & 12 i1) & \multicolumn{2}{|c|}{ (2. $: 37$} & \\
\hline \multicolumn{2}{|c|}{ Putnam $\quad \ldots \ldots \ldots$} & 1045 & 518 & 1010.84 & \multirow{2}{*}{\multicolumn{2}{|c|}{$\begin{array}{l}r=31,5 \\
r 2,204\end{array}$}} & \\
\hline \multirow{2}{*}{\multicolumn{2}{|c|}{ 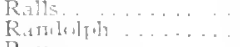 }} & 1320 & tio & $12=47$ & & & \\
\hline & & 1,20 & $4 \div 13$ & $2+1+2$ & \multicolumn{2}{|c|}{$=4,24,3$} & \\
\hline \multicolumn{2}{|c|}{ R.1 ${ }_{\text {R }} \ldots \ldots \ldots \ldots$} & $1 \times 28$ & 51,1 & $2+35$ & \multirow{2}{*}{\multicolumn{2}{|c|}{$\begin{array}{l}24,205 \\
1,5103\end{array}$}} & \\
\hline \multirow{2}{*}{\multicolumn{2}{|c|}{ 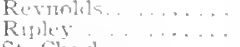 }} & $1+5+5$ & 370 & S', 1 tit & & & \\
\hline & & $1 \backslash \bar{i}$ & 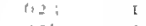 & 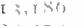 & $S_{1}=$ & 512 & \\
\hline St. Gharle. & & $1 \times 1=$ & 451 & $24+74$ & 221 & 17 & \\
\hline St. Clair & & sind & $7 \overline{7}$ & 17,1177 & 167 & 217 & \\
\hline Ste gentales & & 1212 & +13 3 & $10,3 i 0$ & 13. & 85 & \\
\hline $\begin{array}{l}\text { At Frangon } \\
\text { St. Lintis }\end{array}$ & $\cdots$ & $\begin{array}{lll}1 & 2 & 2 \\
1 & >1 & 1\end{array}$ & $\begin{array}{l}400 \\
4>3\end{array}$ & $\begin{array}{l}2+9 \overline{1} \\
50,-475\end{array}$ & $\begin{array}{l}17,3 \\
30.5\end{array}$ & 37 & \\
\hline St. Lrum,$C_{14}$ & & $1>=11$ & or & 75,$2 ; 4$ & 451,7 & $7-\infty$ & \\
\hline Saline & $\ldots \ldots$ & 1120 & $\therefore \geq 0$ & $3: 70 ;$ & 3.3 .7 & 802 & \\
\hline Silnuster $\ldots$ & $\ldots \ldots$ & 1545 & $\$ 02$ & $r=42$ & 11.2 & 211 & \\
\hline Siontanul... & $\ldots \ldots$ & $12+1$ & $1: i$ & $15: 2: 2$ & 12,0 & $r i t$ & \\
\hline Sicutt. $\quad \cdots$. & $\ldots \ldots$ & $1>=1$ & $+1 i$ & $1 ; .04\}=$ & 11,2 & 25 & \\
\hline Shanninf... & $\ldots \ldots$ & $15+1$ & ני & I i . 2.47 & く. & $6 x$ & \\
\hline Shelloy .... & $\ldots$. & iviz & 500 & 10,$16 ;$ & $I=.1$ & 142 & \\
\hline Srendaria.... & $\ldots \ldots$ & 1 275 & $\therefore ;$ & $2+(1+1)$ & 17 & 727 & \\
\hline Sinene $\quad \cdots$. & $\ldots \ldots$ & I $\backslash \overline{1}$ & 5011. & 13,132 & 7.0 & 110 & \\
\hline Silluan.... & $\ldots \ldots$ & $1>45$ & $14 i$ & 23.292 & IU) $=$ & 2310 & \\
\hline Tanes. . . . . & $\ldots \ldots$ & 1547 & 114 & $1=127$ & 7.11 & 17 & \\
\hline texias ...... & $\ldots \ldots$ & $1>35$ & 1.157 & $=2-11,2$ & I1). 1 & 101 & \\
\hline$V_{\text {extren }} \ldots . .$. & $\ldots \ldots$ & 1 in & in & 31,110 & $3 \mathrm{I}, \overline{5}$ & 25 & \\
\hline Warren .... & $\cdots \cdots$ & I:; & +10 & 13,11113 & 0.0 & 13 & \\
\hline Washingtor. & $\cdots \cdots$ & 1413 & 74 & t. 2013 & $1, \lambda, 1$ & $5 \vdots$ & \\
\hline Wayne......... & $\ldots \ldots$ & 1418 & 779 & $T=3,301$ & 11,0 & 27 & \\
\hline Webster.... & $\cdots \cdots$ & 1355 & $5: 11$ & $11.114=$ & $I=1$ & 78 & \\
\hline Wright .... & $\cdots$ & $\begin{array}{ll}13+10 \\
i x+1\end{array}$ & 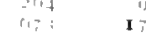 & $\begin{array}{l}13,5 ; 2 \\
7,5: 11]\end{array}$ & $\begin{array}{l}3,7 \\
1+4\end{array}$ & & \\
\hline The & tion & - $4=0$ & uri at Eacl & h $F$ & al C & & \\
\hline & $\begin{array}{l}\text { REA L- } \\
\text { IAB } \\
\text { RANK } \\
\end{array}$ & 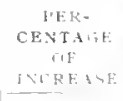 & $\begin{array}{c}\text { INARASE } \\
\text { INTEV } \\
\text { YEAR' } \\
\end{array}$ & 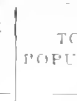 & $\begin{array}{l}\text { AL } \\
\text { ATION }\end{array}$ & $\begin{array}{r}D E \times 4 \\
\text { PE } \\
S \because .\end{array}$ & $\begin{array}{l}\qquad 1 \mathrm{~T} Y \\
\text { ER } \\
\text { III.E }\end{array}$ \\
\hline I410....... & $2 \xi$ & & $\cdots \quad-$ & & 45 & & 3 \\
\hline $1<20 \ldots \ldots \ldots$ & $=;$ & $210+$ & $+5 .+1$ & & $\therefore .26$ & I & 0 \\
\hline I & 21 & 1150 & $8 \sin (x)$ & 14 & 455 & 2 & 1 \\
\hline $1<10 \ldots . .$. & in & $17 i, 2$ & $24 i, 247$ & &, 02 & 5 & t, \\
\hline $1550 \ldots \ldots$ & $i$ & 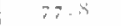 & $20 \times 4+372$ & & .041 & 1) & ") \\
\hline$x>60 . . . .$. & $\therefore$ & 73.3 & 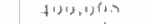 & 1.17 & .012 & 17 & $2^{2}+x-1+3$ \\
\hline$x ; 0 \ldots \ldots$ & 5 & 150 & $=\{1,2.13$ & 1,72 & 205 & 25 & 0 \\
\hline Isso, . . . . . & 5 & 212.0 & $4+7,0,55$ & $2, I^{n}$ & Sho & ₹I & 5 \\
\hline $1500 \ldots . . .$. & 5 & $2 \div 8$ & 510,194 & $\therefore(1 ;$ & I. & (1) & o \\
\hline $1000 \ldots \ldots .$. & 5 & 10.5 & $427.4 \times 1$ & 3.10 & toris 5 & 45 & 2 \\
\hline
\end{tabular}

\section{State or County of Birth of the Population of Missouri}
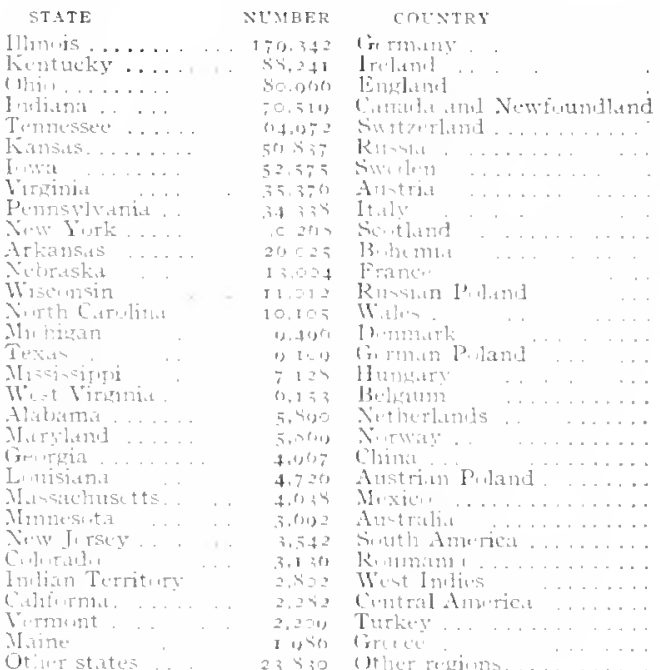

NUMBEF

100.24

31,35

25,600

6,6

$6,6,72$

5,110

$+450$

$4,3+5$

3.45

$3.2 \times 14$

16,3

I. 5 I

1,$4 ; 0$

002
80.4

81
530

$4+3$

in:

144
123

$\begin{array}{lll}1 & 0 \\ 1 & 1 & 1\end{array}$

IOI
Oul

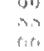

Population of the Leading Cities and Towns of Missouri at Each Federal Census from 1850 to I 900 .

\begin{tabular}{|c|c|c|c|c|c|c|}
\hline & 1000 & $18 y 0$ & 1.550 & 1570 & 1560 & 1550 \\
\hline & 575,$2 ; 4$ & $451,7=0$ & $i 50.51 .4$ & $\div 10 \times 314$ & $1 \log 7 ; i$ & 77,400 \\
\hline$K=\operatorname{lin} n, 14$ & $16+3-5=$ & $1 \leqslant 2-70$ & 55.795 & $: 2=20 x$ & $14 i n$ & $\ldots$ \\
\hline Sit I and & $102.1 \%$ & 52,224 & 32,$4 ; 1$ & $11.50=$ & $\therefore, 1) ;=$ & $\ldots \ldots$ \\
\hline Joglin & 26,$02 ;$ & 9,04 & $7.0 ; 4$ & & $\ldots$. & $\ldots \ldots$ \\
\hline Sirmentivel & $2 x, 20 \%$ & $21.5 \div 0$ & $4,5=2$ & 5.555 & $\ldots \ldots$ & +15 \\
\hline 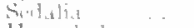 & & $1+0 \mathrm{cos}$ & 1). $5019 !$ & $4=100$ & $\ldots$. & $\ldots .$. \\
\hline 11,13 & so & 12,457 & i 1., 14 & 10819 & $6.50=$ & 2,020 \\
\hline $11 !$ & i) tiret & $0.7+2$ & $2 \div 1$ & $4.4=0$ & t.F: & $\ldots$. \\
\hline$\therefore$ & $1,+1 c_{1}$ & $7,0,5$ & $\because ; ;$ & & $\cdots$ & $\ldots$. \\
\hline 1] City ... & & 3.04 & t. $5 x \mathrm{~s}$ & & & $\ldots \ldots$ \\
\hline (1) & 3.0 & $x 215$ & 10.070 & 1.511 & & $\ldots \ldots$ \\
\hline Sit Itharles & $\therefore, 1,82$ & $n, t+1$ & & $5,5,1$ & 3.2 (1) & $1.40,3$ \\
\hline Nela1 1.1 & 7.4 & $7,21,2$ & & & & $\ldots \quad \ldots$ \\
\hline ce.... & $(t, 1)\}$ & 0.340 & $3,1,41$ & $\sin 4$ & 3,1104 & $\ldots \ldots$ \\
\hline$\ldots$ & & 5,717 & 4.07 .4 & $3,1, ; 5$ & (2) 4 & $\ldots \ldots$ \\
\hline & $(1, \mathrm{r}, \mathrm{l}$ & $i, 4>2$ & $\cdot$. & & & $\ldots \ldots$ \\
\hline & $5.12 r_{10}$ & 3.510 & $2.3+4$ & $1,4: 1$ & $15^{4}$ & $\ldots$. \\
\hline & $5,1,58$ & 4000 & 324 & $2,2 i^{11}$ & 1.414 & 651 \\
\hline D. & & i.otol & (n) & & . $\quad 1$ & \\
\hline & 5.4 .4 & $4=i$ & 2.2844 & $4=2$ & & $\ldots$ \\
\hline & S. ichil & $=.0$ is & 3. $31=$ & i) :- & औा & \\
\hline L.. & $5,1: 1$ & 5.000 & $4 i 25$ & $(1,10)$ & $=4 i t$ & 11 2 \\
\hline & 5.51 & 4.740 & $3 . x_{i} ;$ & $2,0=0$ & 1) & . \\
\hline Ml. & $5.24 \%$ & $4.21,7$ & $x_{n}=1$ & & . & $\ldots$ \\
\hline ili: & 5.0111 & 737 & 2.504 & $1+$ & & $\ldots \ldots$ \\
\hline Fut & 4. Y5: & f.ist & $2.1=01$ & 1.:5 & & $\ldots$. \\
\hline a1t & $1+15=$ & 4,207 & Finso & 3, $84:$ & $=(1) ;$, & \\
\hline$\ldots$ & 4. -24 & $4-56$ & 041 & $2,0,4=$ & $125=1$ & $z+I$ \\
\hline & 7,$5 ;:$ & $4.0: 5$ & 3.45 & $1,10=$ & 427 & $\ldots$. \\
\hline $\mathrm{t}^{2}$ & $4.41=$ & $2 \times 14$ & is: & $\ldots$ & & $\cdots \cdot$ \\
\hline & $48 ;$ & $1+1$ & $3, x=4$ & $\therefore, 500$. & $2.5+10$ & 2.326 \\
\hline & $+2 \geq 1$ & 2197 & 7110 & & $\ldots \ldots$ & $\ldots$ \\
\hline Io & $1,11,00$ & 4.537 & $3,31,6$ & 4. $7:$ & $+1 \therefore$ & 2,0108 \\
\hline & toth & $\because: 3: 1$ & 3040 & $3.01 \%$ & siz & $\ldots \ldots$ \\
\hline & 4,$05 ;$ & +1004 & $\cdots$ & $\ldots$ & $\cdots$ & $\ldots \ldots$ \\
\hline & $3, x_{54}$ & $3.5,4$ & 2,$31 ;$ & $1 \times 8 ; 2$ & 73 & $\ldots \ldots$ \\
\hline & 3.15 & 2315 & 1.424 & 1 & 1115 & $\ldots \ldots$ \\
\hline & $3.15 \%$ & 2.18 & $2,1+2$ & 1,5134 & & $\cdots$ \\
\hline & 3.115 & 1,100 & & & & $\cdots \cdots$ \\
\hline & 3.015 & $2.7 \geq 5$ & 2421 & & - & $\ldots$ \\
\hline & $2,1,7$ & $2,2,7$ & $=100$ & $1.4=5$ & & $\ldots$ \\
\hline & $=1302$ & 2.001 & ऊ得 & 130 & & \\
\hline की & 2.711 & & 7,5 & & & $\ldots$ \\
\hline & & $2 \$ 110$ & U⿴囗十 & $1,1,1 !$ & 107 & $\cdots$ \\
\hline & $\therefore 725$ & $=101$ & 1,613 & 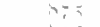 & & 215 \\
\hline 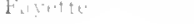 & 2.717 & 2,247 & 1.247 & $>1:$ & 647 & \\
\hline
\end{tabular}




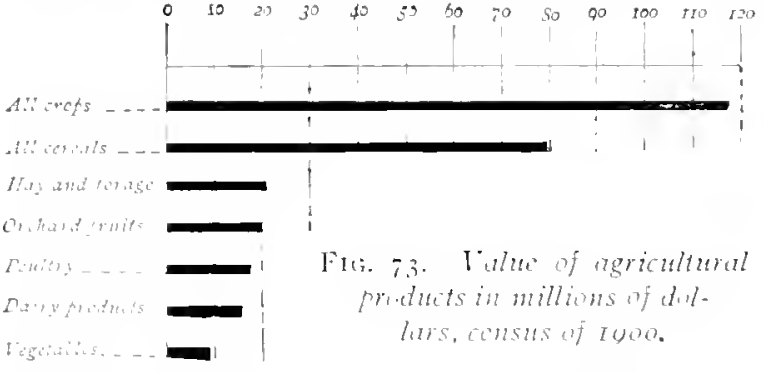

Value of Agricultural Products of Missouri, Relative Rank of State in Production, and Leading County. Census of rgoo.

\begin{tabular}{|c|c|c|c|}
\hline$P R \cap D$ & $\begin{array}{l}\text { RANK } \\
\text { OF } \\
\text { STATE }\end{array}$ & $\begin{array}{l}\text { YUEE RF } \\
\text { P"KUDCCT }\end{array}$ & $\begin{array}{l}\text { IEAWING } \\
\text { COLNTY }\end{array}$ \\
\hline 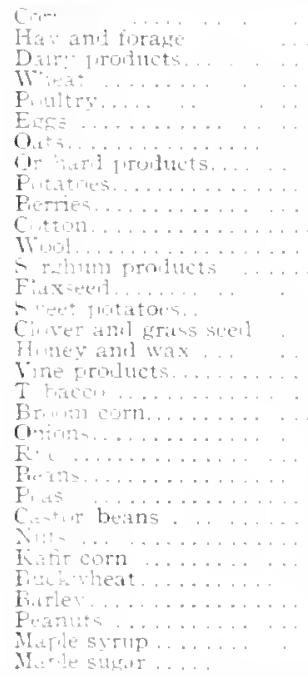 & 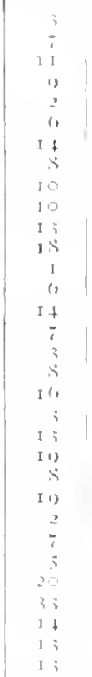 & 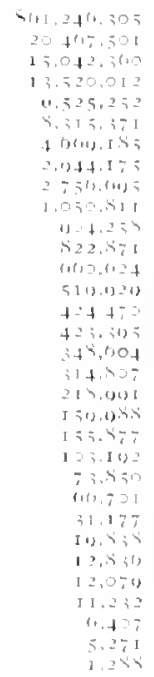 & 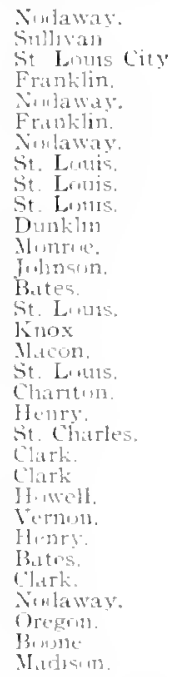 \\
\hline
\end{tabular}

Live Stock Owned in Missouri, I 900.
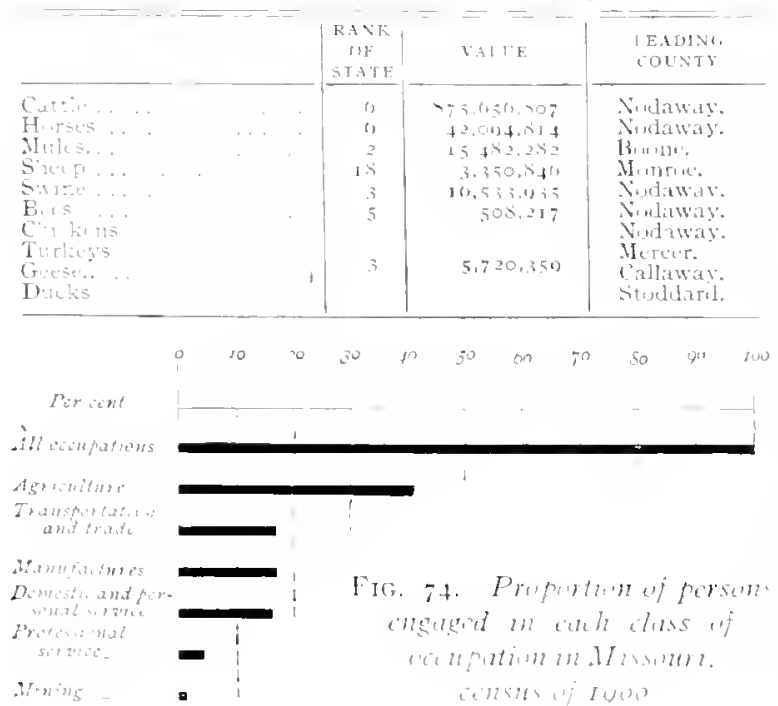

The Manufacturing Cities of Missouri and Facts about their Industrial Plants. Census of 1900.

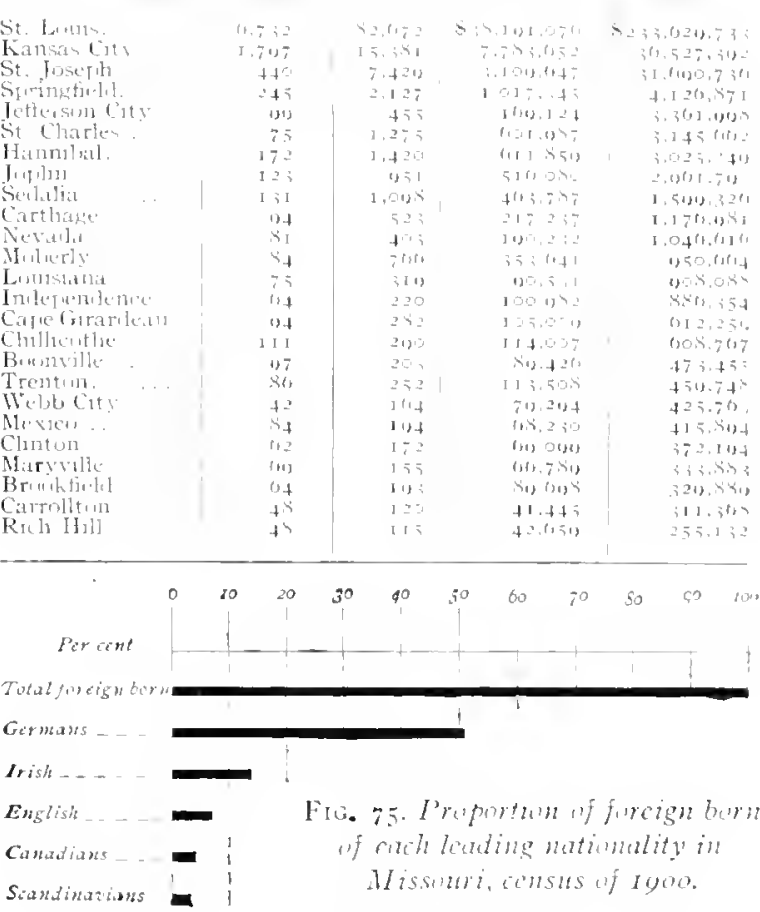

The State and Territorial Governors of Missouri from 1805 to 1906 .

TEKRTTORIA

Gron James Wilkinson

(it) II Thwether Lewas.

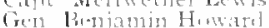

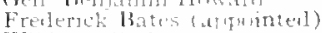

Williame Clark

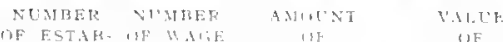

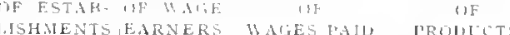

STATE

Alexumber M Nair

Freaterack Bates

Thlow Mildie

I) nomel Dontein

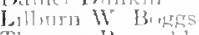

Thunth, Reynestly

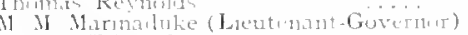

Inthe Eilnathe

Autin A King

Siter]ine Proce

Trustels Folk

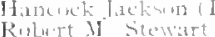

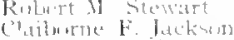

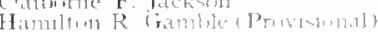

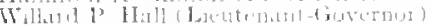

Themlis " Fletelue

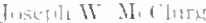

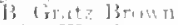

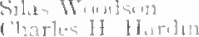

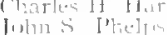

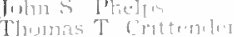

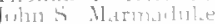

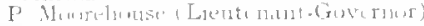

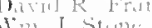

inn of she

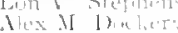

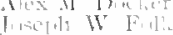

TER:I

1 $197-1$ का

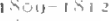

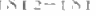

Isi $3-1<20$

$1,20-1424$

1.>2 $125-1$

1.5 $25-1$ is i

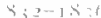

1 $5: 11-1+4$

$13+12-1,4$

$1+4$

1.9.

$452-1,4=1$

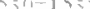

过坛

1.Sin- 1 baj

3isio-1 ister

Q61] 1.tire

sistit-ints

sect-1.)

$\begin{array}{lll}3 & 9\end{array}$

17.2-1

in

insig ins

a

ans 150

Sil $2-I, i\left(y^{t}\right)$

1 पipti-sug

$19130-1100$. 


\section{THE IIDEX}

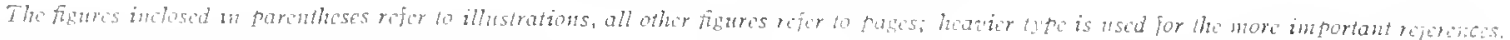

Agriculture, I1, 12: $(1, y, 74)$, xi. Fabius River, 4

Altitude, 3 Farm prulluts, 12, ralute rit (Fir

American School of Osteopathy.

Angora goats, 14 . prize (Fir. 3 ) I 7 .

Apple orchard (Fig. 22), I3.

Apples, 1

Arkansas River, 4, 5, 0 .

Art, 24.

Attorney-General, 21, 23 .

Aurora, 3o; mming scene at (Fik. 35), 13 .

Baird College, $3 \mathrm{r}$.

Banks, I 9 .

Barley, 1

Baryta, 3

Bed rock, 5, 6; distribution of

(Fin si), is

Benton. T. H. 10; portrait of (Fys. 10) 10

Bevier, Is

Bingham, G. C., 24

Black River, 3

Blackberries, 1

Blees Military Academ5, 32.

Blind, School for, 2 ?

Boone, Daniel, 10

Boonvil]e, 22, 32.

Boots, 1., If

Brick and tile, 19

Brookfield, 3 I.

Broomcorn, 12 .

Cape Girardeau, 23, 24, 31,

Carondelet,

Carriages and wagons, ro.

Carrollton, : 2 .

Carterville, 32 .

Carthage, $=9$

Cattle. 14

Cedar Gap Plateau, 3

Cement, $10,20,3 \mathrm{r}$.

Central College, 24,32

Chariton River, 4

Chickens, I

Chillic othe, 22,30 .

Chouteau, Auguste, $\geqslant 5$.

Christian Brothers College, 24

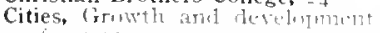
iff $25-32$.

Clay, 5, 7, 8 , werling filant ( Fis?

Clemens, S. L. (Mark Twan), 24,

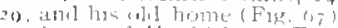

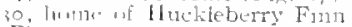
(Fir 138$), 30$

Climate, 8.

Clinton, 31 .

Clothing, in

Clover seed, 12

Coal, 15, 17, I8, 30, 3I, 320, lis

Columbia, 30.

Congressional districts (Fvis. it?

Constable, 2.

Copper, i:

Corn, 12; Firaduction of (Fig, so).

Courts, 2

Cuive River.

Dairying, 5 .

Deaf and Dumb, School for, 23

De Soto, 3

De Soto's expedition, o

Disseminated ote, 1

Doniphan, Alexander W., it : ners-

Drainage, 5

Drury College.

ge, $2+3+2$

Eads Bridge,

Education, 23

Educationa! institutions, lotine

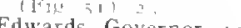

Edwards, Governor, 1

Eldorado Springs,
Excelsior Springs,

Explorations and settlements $\left(F_{3}\right.$.

Hogs, i4, listribution of (Fig 28 ).

Joliet, Louis, t).

Location, I.
Farming: 15 ; 50 (Fig. Iis) 11

Federal Soldiers Home, 2 ;

Field, Eugene, 24

Fisheties,

Flax, 12

Flouring and grist-mill products

i")

Fortuna, 1\%

Foundry and machine-shop fir

Ilictu, Ii]

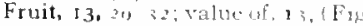
(2) 17

Fruit Experiment Station, 14

Fulton, : $5,24,31$,

Gasconade River, 4 .

Geese, 1 ;

Glasgow. $; 2$

Glass, "11

Governor, 20, 2 3

Grand River, 4 ; in the (Fig. v), 7.

Grapes,

Grass seed, 12

Hannibal, 20; view of (Fig, (3)

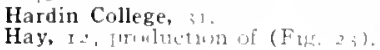

Hardin College, i1.
Hay, I 2, Problucty of (Fur, 23). Mountain G

Higginsville. 23

History, o, 10 I 5, in frasture (Fig, \$1 ), I

Honey, 15

Horses. $y_{4}$ : listribution of ( $\mathrm{F}$. 2ul, io singe at horse mathi (Fit 30$) 10$

Horticulture, $\mathrm{I}_{2}, \mathrm{I}_{3}$.

Huntsville, is

Independence, 30.

Indians, "

Insane, Sinte Hospitals for, I

$\$ 0,31$.

Iron Mountain, 0, Is

Ironton, 0.

Jefferson City, I0, 22, 23, 2y;

Sitil(: 1 Citblisi (Fig. 65 )

Joplin, 29.

Kansas Cíty, 4, I8, I $9,24,27,28$, l. leventis situct (Fis

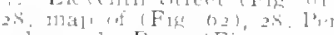

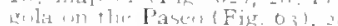

Kansas River, 27

Kearney, General, I.

Kirksville, ? 30 .

Laclede, Pierre, 25

La Salle. is

La Mine Moreau River, 4

Lead, $4,15,16,17,20$, letribition of (Fig. 37 ), is

Lexington, $1,32$.

Liberty, 2,32

Lieutenant-Governor, 20

Lime, 11)

Lime works (Fin ; s), Io

Limestone area, 6, 7, 30, wew if

Lincola Institute. 23

Literature, it

Live stock, I4, 2\$, 21), 3I, 22 ; far

( t) $15^{\circ}: 21,17$

Loess, ' 13

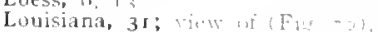

Louisiana Purchase, 10, 27,1 . Ini-

Lumber and timber, I9, 32.

McNair, Alexander,

Macon, 32.
Malt liquors, ro

Mantle rock, 5; listroutum

Ianufacturing, 18 , Io glouth the of

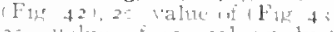

Ifin

Marquette, Pere,

Marshell, 2., 2t. 31

Maryville, $2,32,3$

Meat-packing and slaughtering,

1i), 25 .' 21

Meramed River, 5; scene un (Figs

Méxican War, II.

Mexico,

Mexico Military Academy, 31

Mine I11 Jeatl ant? ame" istre

(1) 15 (a) 1 , s

Mine la Motte,

Mineral resources, $15-18$.

Mining scene (F: 35$), 1,8$

Mississippi River, 1, 3, 4, $5,8,6$ $[0,10,27,20$, i! steamturat , II

Missouri Colony far Feeble Minded Missouri Compromise Bill, 10

Missouri River, $1,4,5,10$ I4, 27,20 , so, revetmont werk 17)

Missouri School for the Deaf, Missouri Valley College, 24,31

Grove, I 3.

ules, 4 , cistribution of (Figs,

Native peoples, 0.

Nevada, ? 30.

Nodaway River,

Norma] Schools, $23,30,31,32$

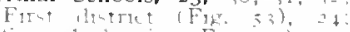
Sicumil Hintrict Fig. 52), 24 .

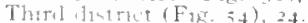

Novinger, Is

Oats, 12. profuction of (Fig. 2क), Osage River, 4

Ozark Border,

Ozark Plateau, $4,4,13,20$

Ozark region, 3, $7,11,1<, 211$

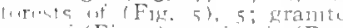

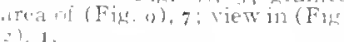

Park College, 24

Parkville, $\therefore$

Peaches, I3: packing, for narket Fige fl, Is. Teach nursirs

Pearl buttons,

Penal institutions.

Pertle Springs.

Physical map (Fir. 4), 4 .

pilot Knob,

Platte Purchase. 10.

Platte River, 4

Political map (Fize z), $=-3$

Poplar Bluff, 32.

Population, levents of (Fis.

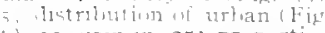
51), 25, gín] 117, 25; propurtion

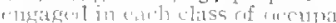

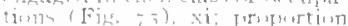

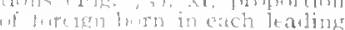
nitiumality (Fig, 73 h, xi.

Potatoes.

Potosi.

Poultry, 15; farme (Fig i4), I

Printing and publishing, I (s.

Pritchett Instrtute.

Prosecuting-Attorney, 22.

Railroad Cars, to tices, Harlinge

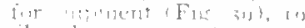

Railroads, II, $27,25,3$

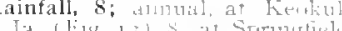

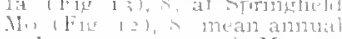

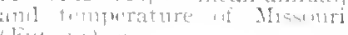

(F) (1), 1).

Relief map if . Mssouri (Fi I), I

Religion, 24.

Rich Hill. 1s, 32.

Robidoux. JosepH, 20 .

Rocks, 5-8.

Rolla, 23 .

Rye, 12,

St. Charles, 10, 30

St. Francis River,

St. Francois Mountains, 3.4 ; tiv St ${ }^{11}$ Fig 21,

St. Ildefonso, treaty of, io.

St. James, 2i

St. Joseph, 1) 23, 28, 29: 1713 af

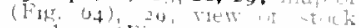

St Youls at (Firs. $41,+5 \%, 20,21$,

t. Louis, 4, $, 1,10,18$,

4. 25, 27: butanical trater

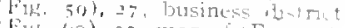
(1) (10), 27 map of ( $F_{12} ; \%$ )

24. Whet trumt (Fjg, 58 )

St, Louis University, 24 !

St. Vincent's College, 24 , 1

Ste. Genevieve, ",

Salt River,

and-clav area, "., 8; dTe tre at Wutk (Fur 40), 10, It is ats (Fik. 11

School of Mines and Metallurgy,

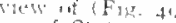

cretary of State, 21, 23

Sedalia, 29.

Settlements, "arlicat explorations incl (Fin. I 5),

Shale area, 11,7 ,

Shaw's Garden (Mssuluri Bchat]-

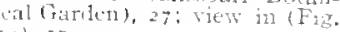
501.27.

Sheep. 14

Sheriff, $2 \mathrm{~T}$

Shoes, is 11

Simmons Mountains. I 7

Size, 1 .

Soils, It, 12: listribution of (Fig. 


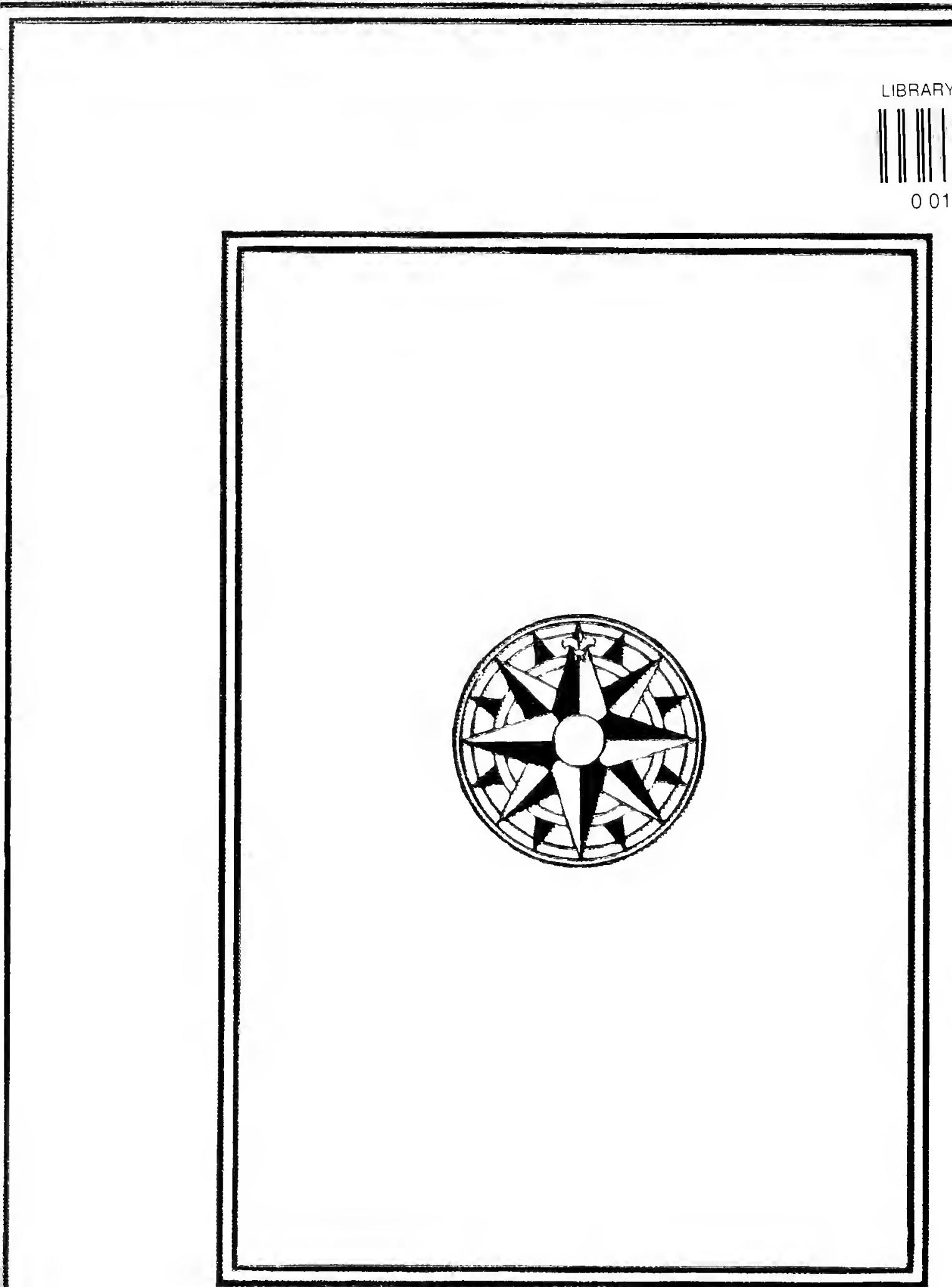

00145713535 